\title{
Serie
}

Estudios de la Comunicación

Nina Aguiar Mariño

Narcisa Medranda Morales

Coordinadoras

\section{Comunicación, desarrollo y política}

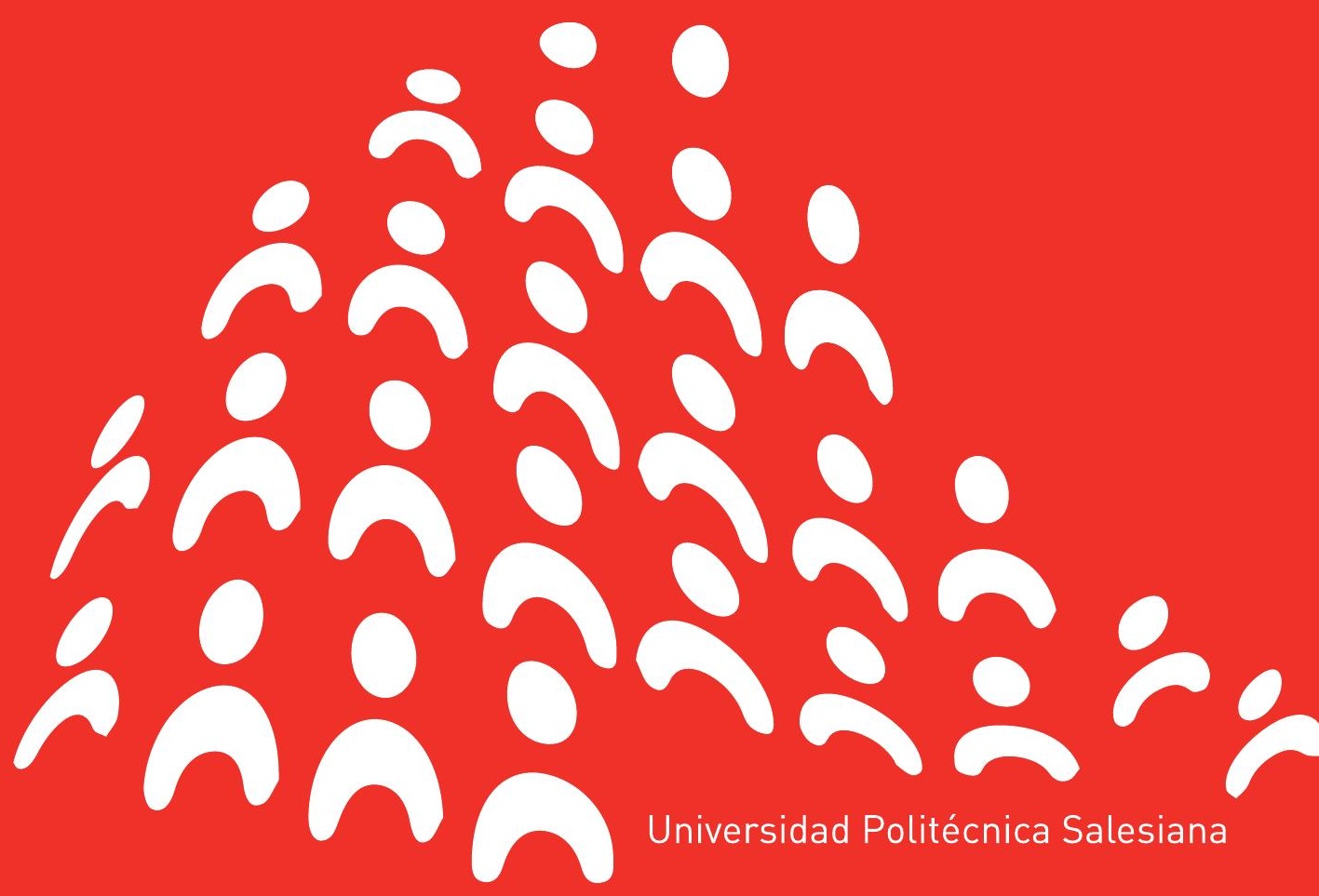


Comunicación, desarrollo y política 

Nina Aguiar Mariño

Narcisa Medranda Morales

Coordinadoras

\section{Comunicación, desarrollo y política}

Serie Estudios de la Comunicación

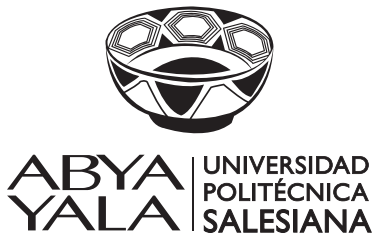

2018 


\section{COMUNICACIÓN, DESARROLLO Y POLÍTICA}

(C) Nina Aguiar Mariño y Narcisa Medranda Morales (Coordinadoras)

Autores: Nina Aguiar Mariño, Roberto Sánchez Montoya, Narcisa Medranda Morales, María del Carmen Ramírez Soasti, Rubén Bravo Castillo, Armando Cuichán Arias, Pablo Romero Guayasamín, Mario Plaza Trujillo, Paula Castelo Ortiz, Jossye Crespo Venegas, Renata Lizarzaburo Palomino

Serie Estudios de la Comunicación

1ra edición: $\quad$ Universidad Politécnica Salesiana

Av. Turuhuayco 3-69 y Calle Vieja

Cuenca-Ecuador

Casilla: 2074

P.B.X. (+593 7) 2050000

Fax: $(+5937) 4088958$

e-mail: rpublicas@ups.edu.ec

www.ups.edu.ec

Área de Ciencias Sociales

y del Comportamiento Humano

CARRERA DE COMUNICACIÓN

Grupo de Investigación: Comunicación, desarrollo y política CODEPO

Derechos de autor: 054575

ISBN: $\quad 978-9978-10-320-3$

Editores Nina Aguiar Mariño, Narcisa Medranda Morales

Roberto Sánchez Montoya

María del Carmen Ramírez Soasti

Edición, diseño, Editorial Universitaria Abya-Yala

diagramación Quito-Ecuador

e impresión

Tiraje:

300 ejemplares

Impreso en Quito-Ecuador, septiembre de 2018

Publicación arbitrada de la Universidad Politécnica Salesiana 


\section{Índice}

Agradecimientos .................................................................... 7

Introducción...............................................................................

PRIMERA PARTE

ACERCAMIENTOS TEÓRICOS DE LA COMUNICACIÓN

Capítulo 1

Desafíos teóricos en la formación profesional de los comunicadores:

Aproximaciones al debate desde Ecuador

Roberto Sánchez Montoya, María del Carmen Ramírez Soasti,

Rubén Bravo Castillo, Armando Cuichán Arias,

Pablo Romero Guayasamín, Mario Plaza Trujillo

Capítulo 2

Aproximaciones teóricas de la transparencia en la información pública local de los GAD Municipales del Ecuador

Narcisa Medranda Morales

SEGUNDA PARTE

IDENTIDAD, REPRESENTACIÓN Y MEDIOS

Capítulo 3

Representación de la identidad adolescente mediante imágenes de Facebook

Nina Aguiar Mariño y Paula Castelo Ortiz.... 


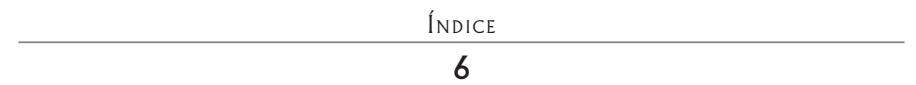

Capítulo 4

Representación de la mujer latinoamericana en el cine comercial Nina Aguiar Mariño y Jossye Crespo Venegas .................................. 93

Capítulo 5

Medios de comunicación privados y poder político en Ecuador 2007-2016

Renata Lizarzaburo Palomino y Roberto Sánchez Montoya ........... 115 


\section{Agradecimientos}

Queremos expresar nuestro agradecimiento a la Universidad Politécnica Salesiana (UPS) por su apoyo. A las autoridades, profesores y estudiantes de la Carrera de Comunicación de la sede Quito, quienes han enriquecido este documento con sus aportes.

Una mención especial para el Vicerrector de Investigación de la UPS, doctor Juan Pablo Salgado, que siempre alentó la formación del Grupo de Investigación Comunicación, desarrollo y política, el mismo que propuso esta iniciativa editorial. Asimismo, estamos muy agradecidos a Hernán Hermosa, coordinador editorial de Abya-Yala, por todas las facilidades para la publicación. Finalmente, queremos destacar el liderazgo de María del Carmen Ramírez en la dirección de la Carrera de Comunicación, UPS-Sede Quito, sin cuyo apoyo este libro no se hubiera podido concretar.

En el caso del primer capítulo los autores agradecen la importante colaboración de los colegas de la Carrera de Comunicación de la UPS, de las sedes Cuenca y Guayaquil, que participación con sugerencias que enriquecieron el documento final. En este proceso se reconoce especialmente la colaboración de Gioconda Beltrán, Jorge Galán y Katiuska Flores, entre otros.

En el segundo artículo la autora realizó su aproximación teórica con base en las propuestas de transparencia de la información planteadas por el Mapa Infoparticipa de la Universidad Autónoma de Barcelona y agradece de forma especial por sus aportes al doctor Pedro Molina Rodríguez. 


\section{8}

Este libro también está dedicado a todas aquellas personas que a diario caminan junto a nosotros, y que sin su apoyo, tolerancia y ayuda no hubiese sido posible esta publicación. 


\section{Introducción}

Como lo han señalado diferentes investigadores de la comunicación, los estudios en este campo, son relativamente nuevos, en comparación con otras disciplinas históricas de las ciencias sociales y las humanidades (Craig, 2003). En el caso de América Latina los departamentos de comunicación social o de ciencias de la comunicación se constituyeron, en las principales universidades de la región, entre las últimas 3 o 4 décadas. En el mejor de los casos se pasó de los antiguos estudios del periodismo a los estudios de la comunicación, en otras circunstancias la nueva disciplina era incentivada por un conjunto de variados profesores de sociología, literatura, lingüística, filosofía, psicología, entre otras ramas.

El origen diverso de los estudios de la comunicación también se manifiesta, en los múltiples temas de investigación, que le da el sentido de interdisciplinariedad, multidiciplinariedad y transdisciplinariedad en el campo de las ciencias sociales y humanas. Por ejemplo, la UNESCO considera que los estudios de comunicación investigan sobre el

... intercambio verbal y no verbal de ideas e información, este campo cubre un rango amplio de temas como teoría de la comunicación, prácticas y políticas, estudios de medios (periodismo, difusión, publicidad, etcétera) comunicación masiva, opinión pública, discurso, redacción técnica y de negocios, así como relaciones públicas (UNESCO, 2010, p. 204).

El objeto de investigación de los estudios de comunicación sigue siendo motivo de debates especialmente en Latinoamérica, donde la teoría crítica ha tenido una gran influencia para teorizar la comunicación desde perspectivas heterodoxas. En los últimos años se han venido afirmando una serie de postulados interdisciplinarios, multidisciplinarios e incluso existen llamados para abordar las investigaciones desde perspectivas transdisciplinarias (Maldonado, 2012). 
Desde Latinoamérica se busca entender la comunicación de manera no rígida ni lineal. Quizá en la región se ha producido la crítica más fuerte a la razón funcionalista, que prima en los estudios de comunicación de Estados Unidos, y que tienen influencia en la mayoría de universidades del mundo. Si bien, los estudios de comunicación fueron conceptualizados inicialmente desde Norteamérica y Europa occidental, en las últimas décadas, desde América Latina se han realizado quizá los aportes teóricos más importes que han enriquecido la disciplina desde una perspectiva con fuerte énfasis en aspectos sociopolíticos y culturales (Barranquero, 2005).

Según Moragás en América Latina las transformaciones sociales, como problemáticas, en los temas de comunicación han sido aún más visibles que en otros contextos. Esto por las problemáticas políticas, sociales y económicas tanto como culturales, que han dado origen a la liberación de teorías dominantes "construyendo su propia intertextualidad teórica, discutiendo, renovando, descartando teorías” (Moragas, 2011, p. 178).

En este marco presentamos la serie de libros, Estudios de la Comunicación, como parte de una propuesta, organizada por los integrantes del Grupo de Investigación de Comunicación, Desarrollo y Política (CODEPO) de la Universidad Politécnica Salesiana- Sede Quito, integrado por los docentes e investigadores Roberto Sánchez Montoya, Nina Aguiar Mariño, María del Carmen Ramírez Soasti, y Narcisa Medranda Morales; que tiene como objetivo vincular a los estudiantes graduados, a sus tutores y a los docentes de la Carrera de Comunicación.

La serie de libros busca fomentar la discusión, el debate y la producción científica desde diferentes ángulos o perspectivas, ya que se considera que el estudio de la comunicación requiere de la búsqueda del diálogo entre teorías de orígenes diferentes, así como de un pluralismo metodológico que conlleve a la resolución de problemas a través de la investigación aplicada o el desarrollo de ensayos teóricos. Es desde ésta 
mirada, que los integrantes del Grupo CODEPO entienden los estudios de la comunicación.

La primera edición de la Serie, Estudios de la Comunicación, tiene por título, Comunicación, desarrollo y política. Este libro, al ser parte de una primera experiencia, incorpora trabajos académicos de carácter diverso que responden no solo a las líneas de investigación propuestas por la Unidad de Titulación de la Carrera, sino también a las líneas de investigación del Grupo de Investigación de Comunicación, Desarrollo y Política (CODEPO).

El compendio, Comunicación, desarrollo y dolítica, está divido en dos partes; la primera parte articula las reflexiones de docentes e investigadores del área de la comunicación. La segunda parte, consta de reflexiones elaboradas por docentes de la carrera y ex estudiantes de la misma, que han logrado indagar en diferentes temáticas de la comunicación.

El primer artículo, Desafíos teóricos en la formación profesional de los comunicadores: Aproximaciones al debate desde Ecuador, considera los desafíos que la Carrera de Comunicación de la Universidad Politécnica Salesiana, debe asumir para la formación profesional de sus comunicadores. Esta labor teórica de debate, sobre la práctica del profesional de la comunicación, inicia con la necesidad de construir el proyecto de rediseño curricular de la carrera, que, además, responde a los requerimientos de los organismos de regulación y supervisión de la educación superior del Ecuador. El objetivo central de la propuesta es sentar las bases necesarias para la formación de comunicadores con una mirada crítica, capaces de aportar a la solución de problemas a través de la generación de procesos participativos y con la experticia y competencias necesarias para diseñar, ejecutar y evaluar proyectos y productos comunicativos, con contenidos y narrativas inclusivas e interculturales desarrollados en entornos mediáticos convencionales e hipermediales, en un horizonte de diálogo permanente para la transformación y emancipación social, con democracia, justicia, equidad y solidaridad. 
El segundo artículo de esta primera parte, Aproximaciones teóricas de transparencia, en la información pública local de los Gobiernos Autónomos Descentralizados Municipales del Ecuador — es importante, porque permite considerar desde dónde se quiere enmarcar el sentido de la reflexión teórica, en relación a la comunicación. Este artículo ofrece al comunicador, herramientas que le permitan transparentar la información en las instituciones públicas, privadas, comunitarias y/u organizacionales; con el objetivo de que ésta sea accesible a la ciudadanía y genere auditoria cívica, eliminando el secretismo en la información pública. El comunicador, debe generar y buscar establecer procesos de transparencia desde su rol en la sociedad. Humanizar la comunicación, de tal manera que ésta no sea utilizada como un marketing político sino que genere mayor posibilidad de participación ciudadana en las acciones de los gobernantes. Este artículo es producto de una investigación más amplia, que se inserta en la metodología del Proyecto Mapa Infoparticipa de la Universidad Autónoma de Barcelona de España.

La segunda parte comprende estudios que se forjaron de un debate interno entre los docentes y exestudiantes de la Carrera de Comunicación. Esta sección contempla tres artículos con diferentes perspectivas comunicacionales.

El tercero artículo, Representación de la identidad adolescente mediante imágenes de Facebook investiga sobre el sujeto comunicacional contemporáneo, y cómo éste recrea su identidad a partir de la utilización de las redes sociales. La investigación pretende indagar como los jóvenes usuarios de entre 13 y 15 años de edad representan su identidad mediante las fotografías que publican en Facebook, y cómo se van creando estéticas de representación que influyen en la forma de identificación de los jóvenes.

El cuarto artículo Representación de la mujer latinoamericana en el cine comercial, no solo responde a la necesidad de señalar cómo se construye la representación femenina en Hollywood, sino a tomar conciencia que dichas representaciones influyen en la mirada de la mujer 
hispana dentro de la sociedad anglosajona e incluso dentro de su propia sociedad. El objetivo principal radica en el análisis e identificación de dichos roles y estereotipos, además de ver qué parámetros promueven el cambio de dichos roles en la mujer dentro de su sociedad y la construcción de la imagen estereotipada en el cine comercial. Derivando indiscutiblemente en la utilización de la imagen de la mujer latina como objeto sexual y sensual.

Finalmente, el texto Medios de comunicación privados y poder político en Ecuador 2007-2016, indaga cómo en el Ecuador algunos de los grandes medios de comunicación privados han estado ligados históricamente a los importantes grupos económicos del país. Este nexo, en varias ocasiones, les permitió negociar con el Estado y la función pública para vivir con ellos en avenencia para gozar de una especie de inmunidad o en caso contrario otros medios fueron utilizados como herramientas de presión. En la presente investigación se demuestra los vínculos de los principales medios de comunicación del país con grandes corporaciones privadas, y se describe cómo cambian las reglas de juego con la llegada de Rafael Correa al poder en el 2007. El nuevo gobierno se propuso regular la propiedad de los medios y aprobó la Ley Orgánica de Comunicación. 



\section{Primera parte Acercamientos teóricos de la Comunicación}





\title{
Capítulo 1 Desafíos teóricos en la formación profesional de los comunicadores: Aproximaciones al debate desde Ecuador
}

\author{
Roberto Sánchez Montoya \\ María del Carmen Ramírez Soasti \\ Rubén Bravo Castillo \\ Armando Cuichán Arias \\ Pablo Romero Guayasamín \\ Mario Plaza Trujillo
}

\section{Resumen}

El presente ensayo parte de la necesidad de reflexionar sobre aspectos teóricos y prácticos contemporáneos en la formación del comunicador a partir del contexto particular ecuatoriano, con énfasis en los debates latinoamericanos y también con mirada global. La propuesta se esboza alrededor de los principales retos en los aprendizajes que deben tener los estudiantes de comunicación para el ejercicio de la profesión. Esta labor fue esbozada por un conjunto de profesores de la carrera de Comunicación de la Universidad Politécnica Salesiana al momento de perfilar el proyecto de rediseño curricular de la carrera profesional, que, debía además, responder a los requerimientos de los organismos de supervisión de la educación superior del país. ${ }^{1}$ Los autores se reunieron a lo largo del 2015, en prolongadas sesiones de trabajo en las cuales fueron redactando de forma colaborativa un documento inicial que luego fue enriquecido con aportes de otros colegas. El objetivo central de la propuesta es sentar las

1 Estas reflexiones presentadas, a modo de breve ensayo, comenzaron a trabajarse como parte del proyecto de rediseño de la Carrera de Comunicación de la Universidad Politécnica Salesiana. Convocados por la Dirección de Carrera de la Sede Quito, un grupo de profesores elaboraron, el año 2015, un primer borrador de la propuesta que se detalla y que fue enriquecida con los comentarios de los colegas de las Sedes Cuenca y Guayaquil. 
bases necesarias para la formación de comunicadores con una mirada crítica, capaces de aportar a la solución de problemas a través de la generación de procesos participativos y con la experticia y competencias necesarias para diseñar, ejecutar y evaluar proyectos y productos comunicativos, con contenidos y narrativas inclusivas e interculturales desarrollados en entornos mediáticos convencionales e hipermediales, en un horizonte de diálogo permanente para la transformación y emancipación social, con democracia, justicia, equidad y solidaridad.

\section{¿Qué comunicador buscamos formar?}

En cumplimiento de los lineamientos del proyecto de rediseño curricular y los objetivos de formación la carrera de grado tiene una oferta académica de nueve niveles, tres del área básica de conocimiento teórico conceptual, de integración de saberes, contexto, lenguaje y cultura; $y$, seis niveles del área profesional, concordantes con el tipo de formación que se plantea, el perfil de egreso, el título que se otorga y la normativa del sistema de educación superior.

Siguiendo los lineamientos del proyecto de rediseño curricular de la Carrera de Comunicación de la Universidad Politécnica Salesiana, aprobado en el 2016 por el Consejo de Educación Superior del Ecuador -CES- e implementado en el 2017, ${ }^{2}$ se establece que el objetivo central de la carrera es la formación de "comunicadores críticos, éticos y responsables, con el dominio de los elementos teóricos, metodológicos, técnicos y tecnológicos para realizar investigaciones comunicacionales de la sociedad y sobre procesos de gestión de la comunicación". Los graduados de la carrera profesional deben estar en capacidad de

2 En cumplimiento de los lineamientos del proyecto de rediseño curricular y los objetivos de formación la carrera de grado tiene una oferta académica de nueve niveles, tres del área básica de conocimiento teórico conceptual, de integración de saberes, contexto, lenguaje y cultura; y, seis niveles del área profesional, concordantes con el tipo de formación que se plantea, el perfil de egreso, el título que se otorga y la normativa del sistema de educación superior. El área profesionalizante, que acreditará los aprendizajes teóricos y prácticos, cuenta con infraestructura física y tecnológica de aplicación y experimentación acorde a los requerimientos que hoy demanda el ejercicio profesional, la investigación en comunicación y la producción de contenidos. 
Elaborar y desarrollar procesos y productos comunicativos, con narrativas inclusivas e interculturales, dentro de entornos convencionales e hípermediales. Construir diálogos sociales con la diversidad y la diferencia, elaborar propuestas en la perspectiva de la transformación y emancipación de la sociedad, con libertad, democracia, equidad, justicia, solidaridad e interculturalidad (Documento Rediseño Comunicación UPS, 2015, p. 4).

Asimismo se espera que los profesionales de la comunicación posean "el dominio de lenguajes y géneros comunicativos para que construyan, deconstruyan y reconstruyan significados y sentidos, a través de discursos que promuevan "formas otras" de vivir, en oposición a las formas de la cultura hegemónica del mercado" (Documento Rediseño Comunicación UPS, 2015, p. 4). Aspectos que afianzarán la formación del comunicador, su sensibilidad, estilo e intereses de producción de narrativas.

¿Cómo afrontar el reto en la formación de comunicadores con las características mencionadas? Asumir la responsabilidad de la formación de comunicadores de acuerdo con las características y particularidades establecidas, se han organizado los aprendizajes en seis componentes. 1) En primer lugar se describe sucintamente la situación contemporánea en el mundo de las comunicaciones. 2) La importancia de la comunicación desde una perspectiva sociopolítica. 3) La importancia del manejo de las narrativas y lenguajes. 4) Los aspectos relacionados a la hipermedialidad y sociedad red. 5) El eje transversal de la planificación y la gestión de la comunicación. 6) Importancia de la investigación de la comunicación.

\section{El mundo de la industria cultural, la comunicación y la información}

Vivimos una era donde el sistema mundo moderno capitalista (Wallerstein, 2005), ha copado todo el planeta. Esta planetarización se manifiesta por el desarrollo científico-técnico y se expresa en una revolución del transporte, nuevos materiales, genética, comunicaciones, informática y telemática, generando la emergencia de sistemas tecno- 
lógicos en los cuales se realizan las interacciones sociales de los sujetos y se posibilitan los intercambios de productos materiales y simbólicos, conectando a regiones, países y grupos culturales diversos. Otra vía que conduce a esta planetarización es el desarrollo del comercio; los mercados acumulan cada vez mayores extensiones en el planeta desarrollando, complejas organizaciones políticas, financieras y empresariales, de carácter multi y transnacionales, las cuales coordinan políticas, planes y programas con diversos países y regiones.

Este sistema mundo tiene la característica colonial fundamentada en un patrón de poder (Quijano, 2014), que organiza el trabajo y la subjetividad. Este proceso mantiene formas de producir, consumir, conocer, comunicar, sentir y vivir, potenciadoras de la modernidad capitalista, entendida como proyecto cultural.

En este contexto la diversidad de culturas, pueblos y nacionalidades, resultan un obstáculo para este proceso modernizador, razón por la cual desaparecen paulatinamente en medio de procesos de dominación. El sistema mundo moderno capitalista, con ideología liberal, promueve: individualismo, competencia, democracia restringidas, éxito personal, ciencia como única forma de conocimiento, dominio del hombre sobre la naturaleza, desarrollo de industrias culturales y mediáticas, explotación del hombre por el hombre y acumulación incesante de riqueza y capital en pocas manos.

Este proceso de hegemonía cultural se realiza a través de mecanismos de: mercado, educación, religión, medios de comunicación y tecnología, que han ido tejiendo una red de instituciones políticas, científicas, educativas, económicas, comunicativas, religiosas y culturales, encargadas de construir las significaciones y sentidos de la producción y regulación de este orden mundial.

Uno de los problemas que tiene la cultura hegemónica moderna capitalista, son el uso ilimitado y la explotación de recursos, situación que genera la contaminación y degradación del ambiente, poniendo en 
serio riesgo la vida no solo del ser humano sino también del mundo vegetal y animal en el planeta. Nos encontramos en la bifurcación entre la conservación de la vida o su destrucción definitiva, lo cual nos coloca en la necesidad de construir culturas y sociedades otras.

Como contraparte, asistimos a la emergencia de redes de movimientos sociales y políticos (Castells, 2012) que se esfuerzan por la deconstrucción y reconstrucción de sentidos, especialmente emancipatorios que desarrollan otras formas de vivir. Al ser la comunicación uno de los mecanismos más importantes en la resignificación de sentidos, es necesario que se dé una transformación en su estructura para pasar a procesos democráticos de participación discursiva que rompan con el monopolio de la producción simbólica que hoy tienen las grandes corporaciones de comunicación. Estas grandes empresas de comunicación operan en función de los intereses económicos de grupos e individuos acumuladores de grandes fortunas.

En la revista Forbes se publica la lista de los personajes más ricos del mundo. En cuanto al sector de las empresas culturales y de comunicación: Carlos Slim aparece con el monopolio de las telecomunicaciones mexicanas y, es el mayor accionista del influyente diario estadounidense New York Times; en una línea similar, Michael Bloomberg, David Thomson, Rupert Murdoch, Samuel Newhouse, John Malone, dueños de influyentes medios de comunicación; igual acontece con los accionistas de Microsoft, Amazon, Facebook, Google, Apple y Disney, quienes figuran entre los cincuenta mayores billonarios (Forbes, 2015) Estas corporaciones definen los contenidos o significados, sustentadas en sus intereses, generando en ocasiones información parcial y manipulada.

La estructura de la propiedad de los medios de comunicación, cuyo mayor peso se encuentra en los grupos que detentan el poder económico, también se replica en el Ecuador, país en el cual, según el informe de la Comisión de Auditoría de Frecuencias, en 2009 existían 1637 concesiones de frecuencias de las cuales 399 corresponden a la televisión abierta, 29 a televisión por suscripción y 1209 emisoras de FM y onda 
corta (Arcotel, 2009). Para enero de 2014 solo el 3,05\% eran medios considerados comunitarios, el 5,5\% eran medios públicos y el 91,45\% medios con intereses privados (Cordicom, 2014). Esta mayoría de medios privados son los que impulsan el consumo, desentendiéndose de las funciones educativas de formación ciudadana y de promoción del diálogo intercultural.

\section{Comunicación y cambios sociopolíticos}

Un enfoque con primacía en los medios y desde una perspectiva funcional, entorpece la comprensión de una comunicación dialógica y relacional (Martín Serrano, 1982; Habermas, 1992; Beltrán, 2014), lo cual limita las posibilidades de una comunicación orientada a la transformación social, así como los procesos de participación, diálogo y concertación, necesarios para construir una sociedad democrática y elevar la calidad de vida.

Esto se vuelve evidente al analizar la oferta académica vigente de tercer nivel, según la información de Senescyt (2015), de treinta universidades del país, que en conjunto suman 76 carreras relacionadas con la Comunicación (Comunicación Social, Periodismo, Publicidad, Producción Audiovisual, Hipermedia). De este total casi una tercera parte (27 carreras) tienen como denominación la formación en Comunicación o Comunicación Social, en su mayoría está enfocada a medios, y solo la Carrera de Comunicación de la UPS, tiene una oferta de comunicación orientada al desarrollo y cambio social.

Por lo tanto, la mayoría de universidades tiene un enfoque comunicacional centrado en los medios, dando como resultado que los comunicadores tengan límites al momento de desarrollar propuestas de comunicación que orienten el desarrollo de la sociedad hacia la equidad, la justicia, la interculturalidad, lo cual supone construir procesos, productos, políticas, planes, programas y proyectos de comunicación, que cuestionen las estructuras simbólicas de dominación y explotación. 
Sin embargo, no solo la orientación centrada en los medios es la causa de la limitada propuesta desde la comunicación a los cambios sociales, políticos, económicos y culturales, sino la incapacidad de mirar e interpretar la realidad y los contextos, situación que viene dada desde el bachillerato, pues según el Instituto Nacional de Evaluación Educativa los resultados de la evaluación Ser Bachiller (INEVAL, 2014), revelan que solo el 31\% de los bachilleres evaluados tienen competencias excelentes en Estudios Sociales, esto sugiere que los profesionales de la comunicación, al no tener una mirada contextual de la realidad, en sus dimensiones económicas, políticas, sociales y culturales, no logran mirar el papel de la comunicación en estos contextos, situación que tampoco logra ser solventada en el nivel de grado.

Por otra parte, los cambios que se suscitan en la sociedad, a nivel ideológico, político, económico, cultural y ambiental, son tan vertiginosos, que la producción de significados y sentidos que realizan los comunicadores quedan desfasados de estos procesos, evidenciando una debilidad, al estar anclados en las viejas estructuras simbólicas que reproducen la dominación. Por esta razón, es necesario que el ejercicio profesional de los comunicadores asuma una actitud crítica y en sincronía con estos cambios.

Por las razones expuestas enfatizamos una aproximación hacia las teorías críticas, que responden a la necesidad de generar una conciencia problematizadora en referencia tanto a la acción de los medios de comunicación, entendidos como instrumentos de legitimación ideológica de las sociedades capitalistas, cuanto al acto comunicativo; sin perder de vista, además, las condiciones de aparición de sus perspectivas teóricas.

El término critica parte del principio que la realidad es producto de la praxis social, lo cual significa que el sujeto y el objeto no están disociados, están preformados socialmente. Ambos, sujeto y objeto, son resultado de procesos sociales muy complejos, por lo que la tarea fundamental de la teoría crítica es reflexionar sobre las estructuras desde las 
que, tanto la realidad social cuanto las teorías que buscan dar cuenta de ella, son construidas, incluyendo, por supuesto, a la misma teoría crítica.

Sobre esta base, consideramos que la comunicación, como praxis cultural, es un campo de lucha de sentidos y significados por la hegemonía con el propósito de construir "nuevo mundo y nueva realidad". En esta línea, la teoría crítica no busca producir verdades, busca producir "efectos de verdad" que sirvan para agenciar la acción política liberadora de la sociedad. En el marco de este análisis, ubicamos como parte de la perspectiva crítica a: las dos etapas la Escuela de Fráncfort (enfoque dialéctico y economía política de la comunicación), a los Estudios Culturales y, finalmente, a las epistemologías del Sur.

Uno de los primeros aportes de la Teoría Crítica, es el cuestionamiento a la Industria Cultural, que busca reducir a los sujetos a la "unidimensionalidad" (Marcuse, 1993). Esta última debe entenderse como la pérdida de la individualidad del sujeto: "el espíritu se desvanece cuando se consolida como un bien cultural y es distribuido con fines de consumo. El alud de informaciones minuciosas y de diversiones domesticadas corrompe y entontece al mismo tiempo" (Adorno y Horkheimer, 1994, p. 55).

En la mirada de la primera generación de la Escuela de Frankfurt, el término Industria Cultural se relaciona directamente con los modos de producción mediática del capitalismo industrial, que convierte a los productos culturales y simbólicos de la comunicación en mercancías. El resultado es, además de la masificación, la alienación cultural de los individuos.

Como parte del enfoque dialéctico, también es importante señalar los aportes de Dorfman, Mattelart y Schiller, entre otros investigadores de la comunicación, quienes, a partir de la definición de industria cultural, plantearon los estudios de la Economía Política de la Comunicación. Su objeto de estudio reconoce los intereses económicos que determinan el funcionamiento de los medios de comunicación, así como también la construcción de ideología a partir de sus discursos y sus incidencias en la sociedad. Ello implica estudiar la propiedad de los medios y ver cómo 
el contenido de estos transmite una ideología que busca perpetuar la hegemonía de la clase dominante. Schiller (1976) señala que los medios de comunicación transmiten una serie de mitos que son la visión ideologizada de la realidad: individualismo y decisión personal, neutralidad, naturaleza humana inmutable, pluralismo de medios y ausencia de conflictos sociales (los conflictos son solo individuales).

Dentro de lo que se conoce como la segunda generación de la Escuela de Frankfurt, Habermas (1992) analiza las condiciones de la racionalidad de la acción social a partir de la interacción basada en el uso del lenguaje, apoyado en el principio de que la razón subyacente en la acción de los sujetos ${ }^{3}$ es una propiedad de las estructuras de comunicación, más no de los individuos por sí solos, ni de los sistemas o subsistemas en los que se desenvuelve la sociedad, aunque reconoce la vigencia de estos últimos. En términos amplios, en la Teoría de la Acción Comunicativa reside la posterior crítica a la sociedad capitalista moderna, ya que somete y debilita la autonomía y la racionalidad del individuo, operando a través de la sustitución de la racionalidad comunicativa por una racionalidad tecnológica. Finalmente, la teoría reposa en la idea de la ética comunicativa como idea de base para consolidar la deliberación pública, en el sentido de una práctica política que oriente a la sociedad hacia una realización emancipadora (Garrido, 2011).

Desde la perspectiva de análisis crítico también se incluye a los Estudios Culturales (Hall, 2010) que originalmente examinaron las relaciones entre cultura y poder desde una perspectiva del sujeto subalterno (desde lo popular), al estilo de Benjamin (2003); por lo tanto este planteamiento analiza las prácticas e instituciones que promueven en la población determinados valores, creencias y comportamientos (Barker, 2000), es decir cómo funciona el proceso ideológico y cuáles son sus mecanismos; además, cómo se concibe la ideología en relación

3 Si bien Habermas defiende la capacidad de los sujetos como importantes actores para la transformación social, tiene serias críticas a los autores que el pasado desarrollaron teorías bajo la idea de un sujeto transcendental. 
con otras prácticas dentro de la formación social. En los ámbitos comunicacionales, los Estudios Culturales plantean que la comunicación no es un hecho natural, y que tanto emisor como receptor tienen una intencionalidad en la construcción y recepción de los contenidos (codificación/descodificación = tipos de lecturas: dominante, negociada y de oposición). Por otra parte, considera que los mensajes de los medios de comunicación son polisémicos y tienen un sinfín de interpretaciones, por lo tanto observan cómo los distintos grupos sociales desarrollan sistemas de interpretación (negociación de prácticas comunicativas) (Rodrigo Alsina, 2001).

En el caso latinoamericano estas propuestas de estudios de comunicación podemos encontrarlas en pensadores como Paulo Freire, Jesús Martín Barbero, Eliseo Verón, Muníz Sodré, María Immacolata Vassallo de López, Armand Mattelart, Luis Ramiro Beltrán, José Márquez de Melo, Raúl Fuentes, Enrique Sánchez Ruiz, Rosa María Alfaro, Armando Silva y Díaz Bordenave, entre otros. Este paradigma crítico se encamina a que, en América Latina, desde la comunicación, se promuevan procesos emancipatorios que se expresan en: la construcción de diálogos sociales e interculturales, para establecer acuerdos y consensos; la participación de las diversidades y las diferencias en los procesos políticos y en la toma de decisiones, que se orienten hacia la construcción de procesos y prácticas comunicativas que busquen la transformación de la sociedad; la construcción de sujetos y ciudadanía para el ejercicio de los derechos; la construcción, deconstrucción y reconstrucción de nuevos significados y sentidos, que abran espacios para transformar las diferentes dimensiones políticas, económicas, sociales, culturales y ambientales, con el propósito de buscar una sociedad más equitativa e intercultural (Barranquero, 2005).

\section{Narrativas y lenguajes}

Son evidentes las debilidades en el dominio de los lenguajes por parte de algunos comunicadores, lo cual se expresa en el uso inadecuado 
de la expresión oral y escrita; la realización de productos comunicativos planos, con estructuras semánticas incipientes; narrativas con poca pertinencia y relación con los contextos y escenarios específicos; manejo de la información con poca rigurosidad periodística, lo cual empobrece la comunicación en el país.

De la misma manera, respecto a la producción mediática, existe una tendencia a privilegiar la farándula y la crónica roja, anclada en la espectacularización de lo cotidiano y la banalización de la comunicación.

Los medios de masas construyeron modelos del mundo para estandarizar a una población que debía regirse por los mismos parámetros en un contexto de fabricación industrial masiva y homogénea. El uso de la narrativa está vinculado al uso del poder (García Marín y Aparici, 2017, p. 21).

Los medios, como empresas culturales de comunicación, funcionan bajo la lógica de la rentabilidad, lo cual les lleva a depender de los ratings y la promoción del consumo y las estructuras simbólicas de la cultura moderna capitalista, en detrimento de los procesos históricos y culturales de los pueblos y comunidades, así como de los procesos de construcción de ciudadanía y del bien común.

A todo esto, se suma que los comunicadores tienen escasos conocimientos y desarrollo de habilidades y destrezas para realizar la comunicación en entornos hipermediales. Los "nuevos" lenguajes, herramientas, técnicas y tecnologías que modifican las formas de hacer la comunicación en estos espacios, son poco conocidos por la gran mayoría de profesionales de la comunicación. Recién se comienza a ofrecer, en las universidades e instituciones que trabajan la comunicación, procesos de formación para cubrir las necesidades en esta área.

En esta perspectiva, las tecnologías emergen con mayor fuerza, rodean y moldean la realidad de la sociedad; los esquemas de comunicación, lenguajes y narrativas empleados se han visto presionados a evolucionar; es decir, adoptar nuevos códigos, reglas y formatos, por la propia 
dinámica de la sociedad, la globalización y el crecimiento acelerado de accesibilidad a la red de redes.

Hoy, la sociedad requiere una nueva producción de sentidos y los lenguajes que utiliza para ello, también requieren la adopción de modismos tecnológicos y dinámicas de intercambios de información en tiempo real; por eso, es necesario construir las capacidades para utilizar elementos hipermediales compatibles con las nuevas plataformas de virtualización e interacción social, de la cual forman parte la gran mayoría de sujetos, quienes vinculan su cotidianidad con la tendencia a una hiperconectividad a la red. El Relato en la Red ofrece la posibilidad de reconstruir los significados de forma individual en función de la recomposición de cada uno de los fragmentos leídos a partir del orden personal de navegación (García Marín y Aparici, 2017, p. 14).

Por otra parte, a pesar de la libertad de expresión que tienen los ciudadanos en la red de redes, se evidencia una insuficiencia de producción conceptual, producción técnica, sentido de pertinencia y proyección mediática con varias plataformas en línea; en la forma de publicación y replicación de información generada por los usuarios de las redes, lo cual se convierte en un reto para el comunicador en su desarrollo de destrezas y habilidades, que permitan la resolución y gestión de problemas de comunicación mediante la utilización de conceptos de lenguaje, planificación y diseño de estrategias conceptuales, textuales, visuales, audiovisuales e hipermediales.

\section{Entorno hipermedial}

El desarrollo de la telemática, informática, cibernética, robótica y genética, modifican nuestra comprensión del mundo. La evolución vertiginosa de internet, las TIC y la conectividad en las últimas décadas, posibilitan una conversación global a la cual se puede acceder si se poseen los conocimientos y los medios tecnológicos necesarios. Esta conversación es instantánea, interactiva, hipertextual y multimedial. 
Al momento, debido al abaratamiento de la tecnología y el acceso a internet, casi el 45\% de los hogares urbanos ecuatorianos está conectada a internet (INEC, 2016) y puede ser partícipe de estos nuevos escenarios y procesos de comunicación, en los cuales tienen la posibilidad convertirse en generadores y a la vez consumidores de contenidos, ${ }^{4}$ realizar multitareas, poseer la capacidad de ubicuidad y percibir el mundo de una manera virtual, en tiempo real.

Este entorno tecnológico tiene implicaciones profundas, transforma los procesos de comunicación y también a los medios que intervienen. Todas las áreas de conocimiento, dimensiones y acciones del ser humano han sido afectadas: los medios de comunicación tradicional atraviesan una profunda crisis, mientras la comunicación interpersonal digital emerge difusamente.

La emergencia y fugacidad de las tecnologías de comunicación provoca fragilidad en los entornos comunicativos y no permite una prospectiva a mediano o largo plazo.

Los procesos de comunicación se complejizan, la humanidad se encuentra en una transición de las mediaciones (Martín Barbero, 1991) a las hipermediaciones (Scolari, 2008); y en este contexto hipermedial, en el que se resignifican conceptos elementales como la privacidad, lo público, la democracia, lo global, lo intercultural, se buscan nuevos mecanismos para que los procesos de la comunicación sean pertinentes. Emerge una narrativa hipermedial. La comunicación preeminentemente oral y textual entre sujetos, se torna cada vez más audiovisual y multimedial.

Es en este contexto donde deben desenvolverse los comunicadores, para ello, deben tener: una formación sólida, el conocimiento, el criterio y las aptitudes suficientes que les permitan gestionar la comunicación en todo el proceso, ya sea desde la planificación, implementación

4 En los últimos años se ha acuñado el término prosumidores para destacar las capacidades de producir y consumir contenidos comunicacionales al mismo tiempo. 
de políticas, planes, proyectos, hasta la generación de contenidos responsables, inclusivos y con criterio de género, con coherencia conceptual, estética y técnica, posibilitando el diálogo social y la construcción, deconstrucción y reconstrucción de sentidos.

Según Pineda (2011) y Castells (2012) el entorno tecnológico ha influido en una nueva mirada donde las tecnologías dejan de ser meros instrumentos, para convertirse en estructuras que permiten otras sensibilidades, escrituras y lecturas de la realidad, estructurando otros valores estéticos, imaginarios sociales y simbólicos como la inmediatez, lo efímero, los espacios no físicos, las relaciones asincrónicas y otras.

La hipermedialidad supone una articulación de todas las formas de comunicación en un hipertexto interactivo y complejo, que integra las diferentes relaciones culturales, producidas por la interacción humana; en este ámbito, el usuario se convierte en el eje de los procesos comunicativos. Referenciando a Scolari (2008), la multimedia es un nuevo lenguaje; el hipertexto es su gramática; el conocimiento es el nuevo nombre de la información; y el tiempo real, el tiempo dominante. ${ }^{5}$

Aquí la comunicación se desplaza a un usuario activo que produce contenidos y navega en una red hipertextual; los medios se definen en función de su reconocimiento y de su autoridad en materia de contenidos; los diferentes formatos y lenguajes confluyen en un mismo soporte; hay un incremento exponencial de la información, generando situaciones de infoxicación (Scolari, 2008). Las tecnologías digitales suponen cambios fundamentales, que promueven adaptaciones de las formas de escritura lineal y analítica de la palabra impresa, a versiones hipertextuales, multimediales, virtuales y de redes; este paso es señalado por Piscitelli (2002) como pensamiento sintético, más intuitivo, emocional y abierto, desarrollado a partir de la digitalización.

5 Desde otra perspectiva, que también vale la pena tener en cuenta, Norman explica que "en todo caso podríamos hablar de dos monólogos, en los que a veces el sistema debe obedecer nuestras órdenes, y en otras ocasiones nosotros debemos obedecer a las suyas" (como se cita en Hassan Montero, 2015). 
Según Jenkins (2008), otro aspecto que caracteriza este "nuevo paradigma” es la convergencia mediática, ésta no implica tan solo un cambio tecnológico; es ante todo un cambio cultural, que afecta las relaciones entre industrias, mercados, géneros y públicos; ya que modifica la lógica y las relaciones entre quienes operan las industrias mediáticas y los consumidores de los medios.

En el caso de los medios convencionales como la televisión, la radio y la prensa esta lógica implica que cada vez se produzcan menos programas con estructuras y narrativas tradicionales, y al mismo tiempo se posibilite el acceso a contenidos paralelos, con narrativas transmedia, crossmedia, multisecuenciales, multiplataforma y multigénero, en las cuales el usuario determine la comprensión final; ello supone que las audiencias organizarán y reorganizarán los contenidos y la interacción de acuerdo con su criterio individual (Jenkins, 2008). La cultura de la convergencia es el futuro, que cobra forma en nuestros días. Los consumidores serán más poderosos en el seno de la cultura de la convergencia, solamente si reconocen y emplean ese poder como consumidores y ciudadanos, como participantes en esta cultura.

Más allá del manejo instrumental de la tecnología que posibilita los procesos de comunicación digital, es necesario una profunda reflexión, en especial de los profesionales vinculados con la comunicación, para impulsar un entorno propositivo y positivo. Es necesario que los comunicadores puedan recuperar y potenciar este ambiente virtual para propiciar los diálogos globales. ${ }^{6}$

\section{Planificación y gestión de la comunicación}

La gestión de la comunicación responde al nuevo paradigma integral de planificación que tiene un carácter integrador y evaluador de la teoría y

6 Desde una perspectiva más pragmática también se podría decir que "en la era digital, necesitamos poner el foco en las conexiones entre todos los elementos de nuestro diseño: medio, palabras, imágenes y sonido. Debemos observar cada mensaje y explorar todas las formas de comunicarlo" (Wurman, Leifer y Sume, 2001, p. 93). 
la praxis. Refiere procesos metodológicos de construcción de cartografías de comunicación basados en una epistemología del método que prima el "saber con", la multiplicidad, la transversalidad, el devenir y la procesualidad, en una dinámica de construcción de pronósticos fundamentados en los discursos sociales, los sentidos y la interculturalidad (Contreras, 2015).

Este paradigma recupera la acción de los sujetos para el cuidado del ambiente, buscando articular el futuro y la memoria acumulada. Planifica la comunicación en función de la diversidad y la diferencia en sus contextos específicos, a fin de generar mayores posibilidades para los sectores y grupos desfavorecidos, considerando la incidencia en los procesos sociales y las formas de intervención.

Gestionar la comunicación posibilita la aplicación de un enfoque y una metodología. El enfoque asume la manera de ver de los sujetos, lo cual determina su praxis social y su discurso; mientras que la metodología define el ordenamiento de su acción. Las condiciones actuales obligan a la selección de problemas y la utilización de los recursos; por ello, la formación de los comunicadores, en un entorno complejo y altamente dinámico y tecnificado, debe permitirles conocer las condiciones de vida y sus entornos para asumir un liderazgo transformador de lo social, económico, político y cultural (Ramos, 1979).

La gestión de la comunicación conlleva un interés por acentuar valor al manejo de la información, para darle sentido a su trabajo, en función de resolver problemas y transformar la realidad (Friedman, 1991). A pesar de la cantidad de profesionales en comunicación en el país, estos procesos son deficientes y en muchas ocasiones no satisfacen la demanda, ni la expectativa social; esto genera la necesidad de una mayor especialización en la gestión y planificación de la comunicación. Es necesario que los comunicadores realicen procesos debidamente planificados, para asegurar la identificación de escenarios y propiciar diálogos sociales.

Los procesos comunicativos no deben ser entendidos solamente como el intercambio de mensajes entre emisores y perceptores, de he- 
cho son procesos complejos que posibilitan y dinamizan la sociedad; por tanto, la comprensión y abordaje que se realicen desde la comunicación, deben considerar conocimientos y destrezas específicas que permitan intervenir la realidad con una mirada crítica y propositiva.

Tampoco se debe mirar a la gestión de la comunicación tan solo como la construcción de productos comunicacionales. Una mirada miope reduce la comunicación a los productos comunicativos, ya que estos muchas veces son propuestos y ejecutados sin los estudios necesarios que aseguren su pertinencia y eficacia; no se toman en cuenta las particularidades y necesidades sociales, económicas y culturales de las comunidades en las cuales se va a intervenir, tampoco se evalúa la gestión y la planificación, y, menos aún, se sistematizan las experiencias para mejorar los procesos de intervención.

\section{Fortalecimiento de la investigación}

En el país existen 76 carreras de comunicación y periodismo (Senescyt, 2015), en su mayoría orientadas a la formación de profesionales para los medios comerciales y el mercado, con incipientes niveles de investigación y al margen de los procesos de desarrollo nacional; en este sentido, para el ejercicio profesional de los comunicadores, se debe fortalecer su vinculación con la sociedad y sus capacidades de investigación y articulación a redes académicas y científicas.

La situación es compleja, la oferta académica de posgrados es escasa, existen pocas instituciones educativas que ofrecen maestrías en el país y, la de doctorados es nula (Senescyt, 2015); esto se evidencia en la escasa producción académica en el campo de la comunicación.

Según la Federación Latinoamericana de Facultades de Comunicación Social —FELAFACS - uno de los problemas de la investigación es que la comunicación, como campo disciplinar, adolece de objeto y métodos propios (Punín, 2012b), por lo que es una actividad de otros campos disciplinares; esto estaría generando entre otras cosas, que sea 
difícil conseguir fondos para las investigaciones en comunicación, incidiendo negativamente en el desarrollo de la producción de conocimientos en este campo. Otro de los problemas es la orientación que tienen las facultades y carreras de comunicación; según Punín (2012b), en la mayoría de carreras y facultades, "los planes académicos tienen acercamientos a la parte práctica y técnica del periodismo (reportería), matizada con el uso de las nuevas tecnologías" (p. 20) o, en su defecto, tienen una orientación hacia el mercado. Además habría que considerar que las universidades que realizan investigación de la comunicación generalmente replican modelos de investigación de Estados Unidos y Europa.

...la formación de comunicadores sociales en la región no parte de un modelo propio - único, sino por el contrario, al igual que los procesos de investigación en comunicación, toman como referencia las propuestas teórico-conceptuales de Norteamérica y en segunda instancia los postulados teóricos europeos (Punín, 2012, p. 154).

Refiriéndose al contexto latinoamericano, Sierra Caballero, considera que:

...el campo académico está devaluado y es objeto de críticas por el mundo empresarial. La proliferación de licenciaturas en comunicación ha devaluado, según la lógica del saber-poder, el valor de los saberes profesionales como parte de la estrategia económica que favorece el dumping social, dejando de lado la misión fundamental de la universidad. Como consecuencia, el desprestigio profesional y el excesivo pragmatismo han impedido el apoyo estatal hacia políticas de investigación básica y la ayuda a la formación de investigadores capaces de renovar el campo, practica y teóricamente (Punín, 2012b, p. 15).

Un problema importante es nuestra raíz cultural, que se caracteriza por la oralidad y no por la escritura, generando serios obstáculos en la construcción textual y el registro documental de los procesos de pensamiento, esto obliga a ser creativos en la construcción de nuevas metodologías como la producción colectiva y la narrativa polifónica, para propiciar la escritura académica en el campo de la comunicación. 
Además de la poca investigación en el país y América Latina, hay falencias en su difusión y tampoco existe una cultura de vinculación a redes académicas de conocimiento. Es importante impulsar en la universidad y en la Carrera de Comunicación de la Universidad Politécnica Salesiana, procesos de investigación, escritura académica y difusión.

El desafío para las facultades y carreras de Comunicación es reorientar sus procesos formativos, para darle peso a la investigación en comunicación, lo cual implica reorientar los currículos para que salgan de sus miradas instrumentales y avancen hacia la búsqueda de la solución de los problemas concretos que tienen las sociedades. La investigación en comunicación, en este sentido, debe ser asumida con seriedad por las instituciones de educación superior y, de forma permanente, facilitar de los espacios, recursos, formación y organización de los talentos humanos.

Cabe recalcar que por la complejidad del objeto de estudio, el campo de la comunicación no puede ser explicado desde un solo paradigma o un conjunto de teorías que constituyan una comunidad científica y formen una disciplina (Kuhn, 2002); es necesario un abordaje inter y transdisciplinario que explique la comunicación desde diferentes perspectivas epistemológicas, para contribuir al enriquecimiento de su campo de estudio. Como proponen una serie de autores que han reflexionado sobre teorías de la comunicación contemporánea, es necesaria una aproximación a la comunicación desde una perspectiva funcionalista-sistémica para dialogar sus postulados con otros paradigmas como el crítico (Karam, 2012; Rodrigo Alsina, 2001). A fin de cuentas, los estudios de comunicación son de carácter interdisciplinario e incluso transdisciplinario, situación que implica la necesidad de plantear diálogos que rompan con la estructura clásica de los paradigmas.

\section{A modo de conclusión}

En la perspectiva señalada, la carrera de Comunicación, asume en su proceso de formación académica el paradigma crítico de la comuni- 


\section{6}

cación que supone que los comunicadores deben asumir una posición orientada a la transformación de la sociedad, lo cual implica trabajar con los sectores y actores sociales excluidos para ubicar sus problemas, determinar sus necesidades y aspiraciones, construir sus propuestas mediante el diálogo social con las diversidades y las diferencias, informar a la sociedad sobre sus problemáticas, necesidades y propuestas y al Estado sobre el alcance de las políticas públicas y orientaciones sobre las normativas que permitan el desarrollo territorial con equidad, solidaridad e interculturalidad.

La formación del comunicador no puede estar al margen del análisis y lectura crítica respecto a los acontecimientos sociales, económicos, políticos y culturales, que marcan el devenir de nuestro país y determinaran el rol que deben cumplir los comunicadores en el ejercicio de la profesión, para la participación social, la construcción de ciudadanías, el ejercicio de derechos, el fortalecimiento de la identidad y el ejercicio pleno de la interculturalidad.

El itinerario de formación y la organización de los aprendizajes trabajados en el proyecto de rediseño curricular de la carrera, deja de lado la mirada instrumental de la comunicación y propone aprendizajes desde la práctica y experimentación. Desarrolla las competencias para la generación de procesos y la formulación, ejecución y evaluación de proyectos encaminados a la solución de problemas o necesidades, en un marco de procedimientos éticos que permitan el ejercicio pleno de la comunicación.

Hemos asumido la responsabilidad de orientar los aprendizajes teóricos y prácticos para la formación integral de los comunicadores, promoviendo la investigación en comunicación, la vinculación con la sociedad y la producción de contenidos que den respuestas a las necesidades de la sociedad en su conjunto, en concordancia con los objetivos nacionales y particularizando los objetivos profesionales. 


\section{Bibliografía}

Adorno, T. y Horkheimer, M. (1994). Dialéctica de la ilustración. Valladolid: Trotta.

Arcotel (2009). Informe Definitivo. Obtenido de https://goo.gl/GMRja9

Barranquero, A. (2005). Latinoamérica en la ruptura del paradigma de la comunicación para el desarrollo. El recorrido de los pioneros en la búsqueda de alternativas democráticas. Punto Cero 10(11), 2o Semestre.

Barker, C. (2000). Estudios culturales: teoría y práctica. En Juan José Igartua y María Luisa Humanes, Teoría e investigación en comunicación social. Madrid: Síntesis.

Benjamin, W. (2003). La obra de arte en la época de reproductibilidad técnica. México: URTEXT.

Beltrán, L. R. (2014). Comunicología de la liberación, desarrollismo y políticas públicas. Madrid: Luces de Gálibo.

Castells, M. (2012). Redes de indignación y esperanza: Los movimientos sociales en la era de Internet. Madrid: Alianza Editorial.

Contreras, A. (2015). El límite es el infinito. Relaciones entre integración y comunicación. Quito: Ciespal.

Cordicom (2014). Listado de medios de comunicación social de carácter nacional. Obtenido de https://goo.gl/a8kkoJ

Documento Rediseño Comunicación UPS (2015). Documento de Rediseño de la Carrera de Comunicación de la Universidad Politécnica Salesiana (UPS). Aprobado por Consejo Superior de la UPS y remitido al Consejo de Educación Superior del Ecuador (CES). Inédito.

Friedman, J. (1991). Empowerment. The Politics of Alternative Development. Massachusetts: Blackwell.

Forbes (2015). La lista Forbes de multimillonarios. Obtenido de https://goo. gl/RMkKrx

García Marín, D., y Aparici, R. (2017). Comunicar y educar en el mundo que viene. Barcelona: Gedisa.

Garrido, L. (2011). Habermas y la teoría de la Acción Comunicativa. Revista Razón y Palabra, 75, febrero-abril.

Habermas, J. (1992). Teoría de la acción comunicativa II: crítica a la razón funcionalista. Madrid: Taurus Humanidades.

Hall, S. (2010). El trabajo de la representación. En E. Restrepo, C.Walsh y V. Vich (Eds.), Sin garantías: Trayectorias y problemáticas en estudios culturales. Popayán: IEP, UASB, IESCP. 


\section{8}

Hassan Montero, Y. (2015). Experiencias de usuarios: Principios y métodos. Obtenido de https://goo.gl/C7EYsB

INEC (2016). Tecnologías de la comunicación y la información TICS 2016. Instituto Nacional de Estadísticas y Censos -INEC. Obtenido de https:// goo.gl/xGiMeg

INEVAL (2014). Resultados de la evaluación Ser Estudiante 2013. Instituto Nacional de Evaluación Educativa. Obtenido de https://goo.gl/9Wvtco

Jenkins, H. (2008). Convergence Culture: La cultura de la convergencia y los medios de comunicación. Barcelona: Paidos.

Karam, T. (2012). Debates y propuestas para repensar las articulaciones entre la comunicación teórica y la comunicación práctica. Diálogos de la Comunicación, 85.

Kuhn, T. (1981/2002): ¿Qué son las revoluciones científicas? En T. S. Kuhn, El camino desde la estructura. Barcelona: Paidós.

Martín Barbero, J. (1991). De los medios a las mediaciones: Comunicación, cultura y hegemonía. México: GG.

Martín Serrano, M. (1982). Las formas posibles de interacción. En Martin Serrano et al., Teoría de la Comunicación. I. Epistemología y análisis de la referencia. Madrid: Alberto Corazón.

Marcuse, H. (1993) El hombre unidimensional: Ensayo sobre la ideología de la sociedad industrial avanzada. Barcelona: Planeta.

Pineda, M. (2011). Nuevas aproximaciones teórica de la comunicación en un entorno posmoderno. Portal Comunicación: Lecciones del portal. Obtenido de https://goo.gl/k5Ugh7

Piscitelli, A. (2002). Cibercultura 2.0 en la era de las máquinas inteligentes. Bue3nos Aires: Paidos.

Punín, M.I. (2012). Análisis de la formación de comunicadores sociales en el Ecuador. Casos: Universidad Central del Ecuador, Universidad del Azuay y Universidad Técnica Particular de Loja. (Tesis de doctorado). Universidad Santiago de Compostela. Obtenido de https://goo.gl/R2iXk5 (2012b). Los estudios de comunicación social/periodismo en el Ecuador. Una visión crítica al rol de la universidad y la academia. Chasqui, $118,8$.

Quijano, A. (2014). Cuestiones y horizontes: de la dependencia histórico-estructural a la colonialidad/descolonial del poder. Buenos Aires: Clacso.

Ramos, S. (1979). El perfil del hombre y la cultura en México. México: UNAM.

Rodrigo Alsina, M. (2001). Teorías de la comunicación: Ámbitos, métodos y perspectivas. Barcelona: UAB. 
Schiller, H. (1976). Comunication and cultural domination. New York: International Arts and Sciences Press.

Scolari, (2008). Hipermediaciones: Elementos para una Teoría de la Comunicación Digital Interactiva. Barcelona: Gedisa.

Senescyt (2015). Consulta de carreras relacionadas a comunicación. Obtenido de https://goo.gl/uTTUFp

Wallerstein, I. (2005). Análisis de sistemas-mundo: Una introducción. México: Siglo XXI.

Wurman, R., Leifer, L., y Sume, D. (2001). Angustia informativa. Buenos Aires: Prentice Hall. 



\section{Capítulo 2 Aproximaciones teóricas de la transparencia en la información pública local de los GAD Municipales del Ecuador}

"El Ecuador es un Estado Constitucional de derechos y justicia" (art.1), de acuerdo con la nueva Constitución (2008). Territorialmente se organiza en regiones, provincias, cantones y parroquias rurales (art. 42 de Constitución). Cada uno de estos niveles territoriales se constituye en Gobiernos Autónomos Descentralizados (GAD), en remplazo a los llamados gobiernos seccionales autónomos. "Estos gobiernos están llamados a regirse bajo los principios de solidaridad, subsidiariedad, equidad interterritorial, integración y participación ciudadana" (Constitución 2008, Art.238).

El Ecuador está dividido en 24 provincias, 221 cantones y 798 parroquias; cada provincia cuenta con un prefecto y cada cantón con un alcalde, mientras que las parroquias cuentan con un presidente de la junta parroquial. Estas autoridades son electas por el pueblo mediante votación popular y universal cada cinco años.

Refiriéndose a los gobiernos municipales, José Swing (2010, p. 8) señala lo siguiente:

Los gobiernos municipales, ejercen jurisdicción en el territorio del cantón. Son personas jurídicas de derecho público, con autonomía polí- 
tica, administrativa y financiera. Los principales órganos del gobierno municipal son el alcalde, máxima autoridad administrativa y el consejo municipal, responsable del ejercicio de la facultad legislativa.

Las competencias exclusivas que la Constitución reconoce a favor de los gobiernos municipales son las previstas en el artículo 264 .

1. Planificar el desarrollo cantonal y formular los correspondientes planes de ordenamiento territorial.

2. Ejercer el control sobre el uso y ocupación del suelo en el cantón.

3. Planificar, construir y mantener la vialidad urbana.

4. Prestar los servicios públicos de agua potable, alcantarillado, depuración de aguas residuales, manejo de desechos sólidos, actividades de saneamiento ambiental y aquellos que establezca la ley.

5. Crear, modificar o suprimir mediante ordenanzas, tasas y contribuciones especiales de mejoras.

6. Planificar, regular y controlar el tránsito y el transporte público dentro de su territorio cantonal.

7. Planificar, construir y mantener la infraestructura física y los equipamientos de salud y educación, así como los espacios públicos destinados al desarrollo social, cultural, y de deportivo de acuerdo con la ley.

8. Planificar, mantener y difundir el patrimonio arquitectónico, cultural y natural del cantón y construir los espacios públicos para estos fines.

9. Formar y administrar los catastros inmobiliarios urbanos y rurales.

10. Delimitar, regular, autorizar y controlar el uso de las playas de mar, riberas, lechos de ríos, lagos y lagunas, sin prejuicios de las limitaciones que establezca la ley.

11. Preservar, garantizar el acceso afectivo de las personas al uso de las playas de mar, riberas de ríos, lagos y lagunas.

12. Regular, autorizar y controlar la explotación de materiales áridos y pétreos que se encuentran en los lechos de los ríos, lagos, playas de mar y canteras. 
13. Gestionar los servicios de prevención y protección, socorro y extinción de incendios.

14. Gestionar la cooperación internacional para el cumplimiento de sus competencias.

En este sentido, los alcaldes deben responder y socializar con la ciudadanía la ejecución de dichas competencias, para dar lugar a informar de manera contextualizada y verificada, la Ley Orgánica de Transparencia y Acceso a la Información Pública del Ecuador, aprobado en mayo de 2004, señala que, entre otras, todas las personas jurídicas de derecho público "están sometidas al principio de publicidad; por lo tanto, toda información que posean es pública, salvo las excepciones establecidas en esta Ley" (art.1). Siendo los municipios personas jurídicas de derecho público, están sujetos enteramente a esta Ley. En España, una Ley similar no se ha aprobado hasta diciembre de 2013.

Uno de los pedidos de la Ley de Transparencia de Ecuador es que las entidades sujetas a la misma deben difundir a través de un portal de información o página web, así como de los medios necesarios a disposición del público implementados en la misma institución, toda la información actualizada, que para efecto de esta Ley se considera de naturaleza obligatoria (art.7). Sin embargo, al revisar aleatoriamente varias páginas webs nos encontramos que esta Ley tiene una implementación muy limitada.

Es por tanto necesario realizar una investigación que nos permita identificar cómo se está implementando la Ley en las administraciones municipales y qué impactos está provocando en la ciudadanía ecuatoriana. Una investigación de esas características ha sido realizada por el Laboratorio de Periodismo y Comunicación para la Ciudadanía Plural de la Universidad Autónoma de Barcelona, fruto de la cual se ha creado el proyecto Mapa Infoparticip@ (http://mapainfoparticipa.com/es), el cual busca justamente identificar la calidad y transparencia de la información y comunicación que publican los municipios a través de sus portales webs. 


\section{Planteamiento del problema de investigación}

No siempre se utilizan o aprovechan los recursos de Internet y de la web social para ofrecer información de calidad ni para alcanzar metas en relación al derecho de acceso a la información en las instituciones municipales.

La Ley Orgánica de Transparencia y Acceso a la Información (LOTAIP, 2004) de Ecuador, en su Título Segundo "De la información pública y su difusión”, considera como información pública:

Todo documento en cualquier formato que se encuentre en poder de las instituciones públicas y de las personas jurídicas a las que se refiere esta Ley, contenidos creados u obtenidos por ella, que se encuentren bajo su responsabilidad o se hayan producido con recursos del Estado (art.5).

Los municipios, al igual que todas las instituciones públicas, tienen la obligación de difundir esta información según los parámetros establecidos por la Ley (Art.7), además de promocionar y garantizar el derecho de acceso a la misma (Art.8).

Tenemos entonces, por un lado, la sociedad de la información y comunicación que dispone de herramientas e innovaciones tecnológicas, que se utilizan en varios niveles e instituciones de la sociedad. Y por otro, un marco legal (LOTAIP), que demanda a las instituciones públicas la difusión de la información a través de estos medios. Hay en ese sentido unas condiciones favorables para la calidad y transparencia en la información que se emite desde las instituciones públicas.

Es por lo tanto necesario, conocer la situación actual respecto del uso de esas herramientas disponibles, concretamente las páginas web, y la manera con la cual la LOTAIP se aplica por parte de los gobiernos locales, en la publicación de información y la calidad y transparencia de la misma. Eso tiene directamente que ver con los procesos comunicativos que se han implementado dentro de las administraciones municipales, los cuales requieren ser analizados para justamente evidenciar cómo se produce y 
publica la información y cómo ésta responde a las exigencias de un marco legal que garantiza el acceso a esa información como un derecho. Para lograrlo existen instrumentos y experiencias disponibles, como el Mapa Infoparticip@, que pueden ser adaptados al caso ecuatoriano.

\section{Justificación de la investigación}

En la actualidad, los medios de comunicación, si bien se encuentran inmersos en el dilema que plantean las nuevas tecnologías de la información, la comunicación, la inmediatez de la noticia, el mundo globalizado, una sociedad más informada y alerta de lo que acontece en el mundo entero, no obstante, siguen siendo agentes, actores y protagonistas de atención mundial.

La gran mayoría de los medios de comunicación social, poseen códigos que regulan el comportamiento ético de sus trabajadores, periodistas, directivos y personal administrativo. Pero también es cierto que la gran mayoría de esos códigos consisten en unas largas listas de lo que se debe y no se debe hacer que finalmente pocos leen y otros pocas más cumplen.

Una sociedad, como la ecuatoriana, que se encuentra en permanente cambio y transformación, mucho de lo cual responde a las dinámicas actuales y globales de las innovaciones en información y tecnología, requiere de una axiología que la sustente y necesita de vastas investigaciones al respecto. Es entonces innegable la necesidad de plantear a la sociedad un trabajo que se interese por la transparencia y la calidad de la información que se presenta a través de la web.

En el Ecuador el 18 de mayo de 2004, se aprueba la Ley Orgánica de Transparencia y Acceso a la Información Pública (LOTAIP), lo cual marca un antes y un después de la comunicación en las instituciones públicas del País, ya que condiciona a las instituciones del Estado a transparentar sus gestiones a través de los espacios de comunicación tales como radio, prensa, televisión e Internet, es decir a partir de espacios de acceso libre a la información y comunicación. Este interés está 


\section{6}

también presente en el ámbito internacional, como es el caso de España que promulgó la Ley de Transparencia y Acceso a la Información Pública en el 2013.

Una de las prerrogativas de la LOTAIP es la existencia de un control social a través de la participación popular en la gestión de la administración pública, es así, que la acción que ejerza la sociedad en el control social se deriva de la calidad y el nivel de transparencia y divulgación de información de la gestión pública (Arruda, y Teles, 2010). Por lo tanto, es imprescindible que dicha información responda a criterios de veracidad y transparencia, lo cual es posible evaluar.

Partiendo de esta premisa, la presente investigación plantea que, en lo referente a la comunicación pública, se puede aportar para revisar el sistema de gestión pública de la información y sugerir mejoras en la misma. Además de propiciar una toma de conciencia en las autoridades con relación a la aplicación de la LOTAIP. La investigación es por tanto de interés para los responsables políticos de las administraciones municipales y de otras instituciones que han de velar por el cumplimiento de la legislación sobre acceso a la información. Será igualmente válida para los responsables técnicos ya que les aportará criterios y modelos útiles para el desempeño de su trabajo. También los resultados serán interesantes para el conjunto de la ciudadanía ya que al procurarse la mejora de la información publicada en las webs de los municipios se avanzará en el logro de derechos y en las posibilidades de participación fundamentada en el conocimiento de las actuaciones de los responsables políticos. Por último, la mejora de la información pública ha de repercutir en la mejora de los flujos de información hacia el resto de los medios de comunicación, ya que la información pública es fuente fundamental del sistema comunicativo.

Para ello, está investigación se inscribe en la metodología de Mapa Infoparticip@ del Laboratorio de Periodismo y Comunicación para la Ciudadanía Plural de la Universidad de Barcelona, la cual ha desarrollado una metodología de evaluación de los niveles de calidad y 
transparencia en la información de las páginas web de municipios en España, y que sería importante replicar en la experiencia ecuatoriana, con los ajustes necesarios. Por tanto, esta investigación será una aportación significativa en el campo de los estudios de comunicación en Ecuador.

\section{Marco teórico}

\section{Antecedentes teóricos del tema}

En la búsqueda realizada del estado del arte de la presente investigación, hemos encontrado algunos trabajos que están dentro de los ejes de esta propuesta, que son calidad y transparencia en la información y comunicación pública, la experiencia más significativa al respecto, es la línea de investigación en la que trabaja desde 2007 el equipo del Laboratorio de Periodismo y Comunicación para la Ciudadanía Plural de la Universidad Autónoma de Barcelona, que ya ha producido resultados y literatura de referencia.

Esa experiencia ha generado también inquietudes investigativas fuera de España como la tesis elaborada para el Programa de Posgraduación en Ciencias Contables de la Universidade do Vale do Rio dos Sinos - UNISINOS (Porto Alegre, Brasil) realizada por Vagner Naysinger Machado, titulada Fatores explicativos do nível de evidenciação nas páginas eletrônicas de municípios do sul do Brasil, dirigida por la doctora Clea Beatriz Macagnam, leída en enero de 2014, esta investigación buscaba revisar el nivel de información de la gestión pública en los municipios más poblados del sur de Brasil, a través de la difusión de la información en sus páginas web disponibles en Internet, para esto se aplicaron 86 indicadores partiendo de la metodología del Mapa Infoparticipa.

Hay otros trabajos que realizan estudios referentes a este tema, aunque desde enfoques diversos y desde otras disciplinas. Entre los que podemos citar:

Tesis elaborada para la Facultad de Ciencias Físicas y Matemáticas del Departamento de Ingeniería Industrial de la Universidad de 
Chile (Santiago de Chile-Chile) realizada por José Daniel Sousa Oliva, titulada La experiencia de Chile en la transparencia y acceso a la información: el cambio institucional del gobierno central ante las nuevas disposiciones normativas, dirigida por el doctor Álvaro Vásquez Valdivia, leída en 2010, la cual plantea que en el primer año de la implementación de Ley 20.285 en las instituciones del Gobierno Central de Chile hubo factores que se resolvieron adecuadamente tales como la coordinación de los equipos de trabajo en los momentos previo de vigencia de la Ley, la capacitación a los funcionarios públicos, el visible liderazgo de la autoridad al involucrarse en la transformación de las instituciones. Sin embargo, se encontró con que existen temas que dificultan la aplicación de la Ley, como es el caso de los vacíos legales de la misma y de su reglamento que repercuten directamente en los procesos.

La tesis elaborada para la Facultad de Ciencias Económicas y Empresariales, Departamento de Administración de Empresas de la Universidad de Cantabria (Santander- España) realizada por Guadalupe del Carmen Briano Turrent, titulada Factores institucionales que inciden en la transparencia del gobierno corporativo: un estudio en empresas cotizadas latinoamericanas, dirigida por el Dr. Lázaro Rodríguez Ariza, leída en 2012, señala que los factores institucionales formales y los gobiernos corporativos, con el nivel de transparencia, ha sido de gran relevancia en los últimos años.

Sin embargo, la mayor parte de las investigaciones se han enfocado en el grado de divulgación de la información voluntaria como es el caso de la tesis titulada La experiencia de chile en la transparencia y acceso a la información: el cambio institucional del gobierno central ante las nuevas disposiciones normativas de José Daniel Sousa Oliva, de la Universidad de Chile, antes mencionada. Podemos ver que son escasos los trabajos que se centran particularmente en la transparencia de los gobiernos corporativos. 


\section{Infoparticip@}

Infoparticip@es un proyecto del Laboratorio de Periodismo y Comunicación para la Ciudadania Plural de la Universidad Autónoma de Barcelona. Este proyecto surge "como un prototipo de periodismo para facilitar la participación de la ciudadanía plural en el control democrático" (Moreno, Molina, Corcoy, 2013, p. 785). De esta manera busca dar cuenta del rol del periodismo frente a los desafíos contemporáneos de los gobiernos, las democracias en un contexto de revolución tecnológica que implica la era de la comunicación y el Internet.

Las inquietudes de quienes conciben este proyecto tienen que ver con un periodismo que "se ha deshumanizado y ha dificultado así la participación ciudadana en el control democrático" (Moreno, Molina, Corcoy, 2013, p. 784). Lo cual ha restringido la posibilidad de construir una democracia participativa, quedándose ésta en el ámbito de la representación. De esta manera, el periodismo, ha dejado de lado su función como cuarto poder y se ha quedado enmarcado dentro un rol más bien funcional a los gobiernos de turno y no tanto como un aspecto fundamental de la construcción de la democracia.

Es por tanto necesario, e incluso fundamental para la democracia, llevar a cabo acciones que permitan renovar al periodismo y darle una calidad humana. Que no se queden únicamente en el "márquetin político o comunicación estratégica" sino que estén verdaderamente al servicio de la ciudadanía (Moreno, Molina, Corcoy, 2013, p. 505). Es a través de las herramientas propias del periodismo y la comunicación que es posible estrechar las distancias entre gobierno y ciudadanía en términos de transparencia y de participación.

Para Infoparticip@, la construcción de un periodismo con calidad humana responde a los siguientes criterios (Moreno, Molina, Corcoy, 2013, p. 797). 


\section{0}

- Humanizar la información. Lo cual implica tomar en cuenta a las y los ciudadanos en toda su diversidad y como sujetos activos dentro de la gestión pública.

- Información completa y transparente.

- Información con memoria y contextualizada. Que va más allá de la noticia y responde a un contexto socio histórico específico.

- Información contrastada y contrastable. Por tanto, que utiliza fuentes diversas y apropiadas, ofreciendo todos los datos necesarios para poder establecer comparaciones.

- Información periodística, inteligible y comprensible, que responde a las características de una determinada población y que es comprensible para toda la ciudadanía.

Por el lado de la ciudadanía, el proyecto busca que su participación sea "fundamentada", y ese es el punto de encuentro entre el periodismo con calidad humana y la ciudadanía, puesto que, para poder participar, la ciudadanía necesita conocer y para poder conocer necesita la información que es emitida por los periodistas de las administraciones de gobierno. Son las mismas administraciones de gobierno quienes deben producir y emitir información sobre sí mismas, saneada y de calidad, que no esté al servicio de los intereses de los que las gestionan sino de las ciudadanías y los ciudadanos a quienes se deben.

Una de las entradas para el análisis de la información emitida por los gobiernos por parte del proyecto es la de transparencia, tomando en cuenta que es la transparencia en la información lo que genera confianza en la ciudadanía y lo que motiva su participación. Esa transparencia implica no sólo una manera de prevenir la corrupción, sino que se la considera un derecho democrático. Para poder ejercer ese derecho, la ciudadanía requiere de una información transparente, completa e inteligible

En ese contexto, Infoparticip@ busca ser una "propuesta para la innovación del periodismo orientada a facilitar la participación ciudadana en el seguimiento y la evaluación de la actuación de los representantes políticos y las políticas públicas” (Moreno, Molina, Corcoy, 2013, p. 505). 


\section{Aproximación teórica}

\section{Transparencia en la información pública}

Es una verdad indisputable y una de las bases de la ciencia política, entre más estrictamente seamos vigilados, mejor nos comportamos

(Jeremy Bentham).

El término transparencia nace en la Antigua Grecia y China, con el objetivo de contar con gobiernos de leyes (De León, 2008), refiriéndose al beneficio que generan las leyes para la comunidad, logrando de esta manera el respeto y atención por parte de los ciudadanos.

Otros autores como Confucio y Aristóteles, enfatizaron que "un buen gobierno está determinado por la discreción de sus líderes”, lo que significa que los gobernantes deberán cautelar aquella información que sea frágil para sus economías.

La riqueza de las naciones, según Adam Smith se basa en gobiernos con reglas precisas y predecibles (De León, 2008), lo que permite tanto a los ciudadanos como a las empresas, tomar decisiones acertadas con base en información fiable.

Para Kant, una sociedad está formada por “(...) la franqueza, apertura, predictibilidad de las reglas y leyes de una sociedad” (De León, 2008, p. 13). Jean Rosseau enfatiza que "la oscuridad y secretividad son los enemigos de las sociedades” (De León, 2008, p. 13). Lo que significa que los gobiernos, en su gran mayoría han mantenido procesos de opacidad, donde las políticas no se cumplen, que como resultado se ha creado un panorama de desconfianza en la sociedad.

Los primeros indicios de una Ley de acceso a la información se remontan al año de 1766 en Suecia (De León, 2008), la cual incluía el acceso a los documentos oficiales, convirtiendo a éste país en el primero en el mundo con una ley basada en el acceso a la información pública como un derecho constitucional de los ciudadanos (Sveriges Riksdag, 2012). 


\section{2}

Posterior a la ley de Suecia, aparece la Declaración francesa de los derechos humanos de 1789, en el artículo 15 expone que "la sociedad tiene el derecho de pedir a cualquier agente público que dé cuenta de su administración" (Canavaggio, 2011, p. 2). Para 1794 la ley francesa de acceso a la información pública, convierte el acceso a la información en un derecho cívico. Estas leyes se consideraron como la primera generación de leyes de acceso a documentos públicos, que se aplicaron de forma progresiva durante los siglos XIX y XX (Canavaggio, 2011).

El artículo 19 de la Declaración Universal de los Derechos Humanos de 1948, otorga el derecho a cualquier individuo de "buscar, recibir y difundir las informaciones y las ideas de cualquier modo que sea" (Canavaggio, 2011, p. 2). Lo que significa que promueve la libertad de expresión e información.

La segunda generación de leyes se origina por la información militar encubierta durante la Segunda Guerra Mundial (Sandoval Almazán, 2015), se originó una fuerte presión a nivel internacional, para establecer una nueva diplomacia con la finalidad de reducir riesgos en la guerra y la política armamentista (De León, 2008).

Finlandia (1951), EE.UU. (1966), Dinamarca y Noruega (1970), Francia y Países Bajos (1978), Australia y Nueva Zelanda (1982) y Canadá (1983), adoptan las leyes de acceso a la información pública, es por esto que se considera a estos países como los pioneros en materia de transparencia.

Una de las herramientas influyentes para el acceso a la información, aparecen en la Declaración de Chapultepec en 1994, afirmando que: "las autoridades deben estar legalmente obligadas a poner a disposición de los ciudadanos, en forma oportuna y equitativa, la información generada por el sector público", sin embargo no fue establecida como una norma, pero dio paso a una serie de sucesos en materia de transparencia y acceso a la información pública (Escobar, 2015). 


\section{Iberoamérica y la transparencia}

Susan Piotrowski señala que a nivel mundial de 198 países más de ochenta cuentan con leyes o regímenes de libertad en la información (Piotrowski, 2010); éstas se asocian al control y la rendición de cuentas a nivel gubernamental, disminuyendo la brecha en la información entre el pueblo y el gobierno, otorgando el poder a la ciudadanía de responsabilizar al gobierno de sus decisiones. Se espera que la relación entre ambos actores fortalezca la democracia (Puga, 2014)"type" : "article-journal", "volume" : "23" \}, "uris" : [ "http://www.mendeley. com/documents/?uuid=eaf46920-c80d-4cc8-a094-869550d8b8dc”] \} ], "mendeley" : \{ "formattedCitation" : “(Puga 2014, la expectativa que se genera de esta colaboración entre el pueblo y el Estado se verá reflejada en la justicia social y la eficiencia económica.

Según Escobar (2015) "Un documento de innegable referencia para el ámbito iberoamericano, aun sin valor normativo pero de gran influencia, son los Principios de Lima de 16 de noviembre de 2000 sobre derecho de acceso a la información" (p. 62); este documento ha recogido la participación de organizaciones de la sociedad civil, relatores de opinión y expresión de la Organización de las Naciones Unidas (ONU) y la Comisión Interamericana de Derechos Humanos (CIDH) vinculadas en temas de transparencia, cuyo punto de partida es "el acceso a la información como derecho humano", en el cual se expone el siguiente párrafo:

Toda persona tiene derecho a la libertad de buscar, recibir, acceder y difundir informaciones sin interferencias de las autoridades públicas, previa censura ni restricciones indirectas por el abuso de controles oficiales, y sin necesidad de expresar la causa que motive su ejercicio. El acceso a la información es un derecho de las personas y al mismo tiempo una exigencia de una sociedad democrática. Es un derecho tanto de quienes lo ejercen en forma activa como de quienes esperan recibir la información a través de los medios de comunicación y/o de fuentes oficiales (OEA, 2000). 
Cabe destacar que para mantener la democracia y fomentar la participación ciudadana, el acceso a la información es el componente esencial, sobre el cual se sentarán las bases de una sociedad informada, que participará activamente en pro del cambio para su ciudad, país o región en conjunto con el Estado, lo que cambia la dinámica de trabajo y el papel que desempeñan tanto el ciudadano como el gobierno en el desarrollo de la economía.

Posteriormente en el mismo año, se aprobó la Declaración Interamericana de Principios sobre la Libertad de Expresión, reafirmando el apoyo con base en:

El Artículo 13 de la Convención Americana sobre Derechos Humanos que establece que el derecho a la libertad de expresión comprende la libertad de buscar, recibir y difundir informaciones e ideas sin consideración de fronteras y por cualquier medio de transmisión (Unesco, 2012).

Es evidente que el artículo antes mencionado, otorga a todo individuo sin excepciones el acceso libre a la información, sin embargo, existen limitaciones en el caso que la seguridad nacional y la sociedad se encuentren amenazadas o en peligro.

Pero ¿qué ha llevado a Iberoamérica a formar parte de la aclamada transparencia? Varios autores coinciden que la transparencia está relacionada a la lucha contra la corrupción, sin embargo, según varios estudios, aunque los países hayan establecido políticas de transparencia, sus índices de corrupción no han disminuido.

En vista de los recurrentes problemas generados por la falta de transparencia en América Latina, han surgido varias iniciativas desde la sociedad civil, organizaciones privadas y académicas. Cunill (2006) expone que la transparencia es uno de los valores actualmente más apreciados, la revalorización de la democracia y la libertad ha conllevado a la rebeldía y que sean terceros quienes deciden qué debe conocer la ciudadanía. Latinoamérica no ha sido la excepción, impulsando a la creación de las leyes que garanticen el libre acceso a la información pública.

A partir del siglo XX, 16 países de América Latina han adoptado políticas de transparencia y acceso a la información (Unesco, 2012): Ja- 
maica, Panamá, Perú y México (2002); San Vicente y Granadina (2003); Antigua y Barbuda, República Dominicana y Ecuador (2004); Honduras (2006); Nicaragua (2007); Guatemala (2008); Chile (2008); Brasil y El Salvador (2011) y Guyana (2013). Para el siglo XX la transparencia tomó participación en tres áreas: Relaciones internacionales, Gobierno Nacional y Gobierno Corporativo.

En América Latina: Colombia (1985), Belice (1994) y Trinidad y Tobago (1999) (Unesco 2012), establecieron leyes de transparencia en pleno siglo siglo XX, sin embargo no ha sido un factor determinante a la hora de evaluar el avance en los procesos en materia de transparencia.

El mayor obstáculo para el avance en la transparencia pública se debe a que las leyes quedan escritas en papel, no obstante, a pesar de los esfuerzos son escasas las entidades u organismos veedores que trabajen por el cumplimiento o seguimiento de las mismas, empero en la última década esto ha significado una oportunidad para la sociedad civil, que ha visto un crecimiento exponencial en la participación ciudadana con base en proyectos impulsados desde la ciudadanía.

Cabe indicar que el acceso a la información pública es la columna vertebral de la transparencia. La cual se define como el derecho a recibir de forma eficaz y oportuna cualquier información que haya sido elaborada, recibida o procesada con fondos públicos y que se encuentre en poder del Estado. ${ }^{7}$

La información pública se define como "la información que posee un organismo o institución pública, sin importar el formato, la fecha que fue creada, sus autores ni si está o no clasificada" (Solimano, Tanzi, Del Solar, 2008). En la medida en que aumenta la disponibilidad de la información en poder del Estado se generan las bases para una gestión transparente (Solimano, Tanzi, Del Solar, 2008).

7 Ver la tesis de José Daniel Sousa Oliva (https://goo.gl/AjwuWj). 


\section{6}

La transparencia consiste en respetar y cautelar la publicidad de la información y facilitar el acceso de cualquier persona a ella, a través de los medios y procedimientos legales. La transparencia mediante la divulgación y el acceso a la información pública se puede considerar como uno de los derechos humanos fundamentales (Bellver y Kaufmann, 2005).

\section{Participación ciudadana}

En una cultura individualista y fragmentada, como la contemporánea, que atiza intereses particulares, que fomenta, como propósito de vida, el éxito económico individual, o a lo mucho familiar, por sobre cualquier otro propósito colectivo, hace que la ciudadanía sea vea enfrentada a fenómenos de precariedad y, por ende, los sentimientos de inseguridad le invaden y los vínculos sociales se fragilizan.

Frente a estos problemas sociales que viven constantemente las sociedades, la comunicación pública puede ofrecer espacios de construcción de ciudadanía tanto en la forma tradicional de hacer política, así como en el ámbito social. Para ello es necesario fomentar la participación pública en el ámbito tradicional de hacer política, como son los partidos políticos en tanto "instituciones formales, jerarquizadas, burocráticas que median entre la población y el gobierno y cuyo objetivo es el acceso al poder" (Dascal, 2007, p. 35). Cabe señalar, que para los fines de este proyecto la participación de la ciudadanía a través de los partidos políticos es importante, como también lo son las participaciones de las organizaciones sociales y la participación individual de cada persona, ya que, el proyecto responde tanto los intereses personales como colectivos.

Desde una visión de la participación como un derecho, podemos acoger la propuesta de Segovia y Dascal, quienes plantean 5 entradas para el ejercicio de este derecho:

- Derecho a ser informado

- Derecho a opinar

- Derecho a impugnar legalmente las decisiones de la autoridad 


\section{7}

- Derecho a confrontar ideas y llegar a consensos

- Derecho a decidir

Para el presente estudio, y tomando en cuenta el marco constitucional del Ecuador a través de la LOTAIP, es importante describir el derecho a ser informado y el derecho a opinar. Los autores señalados describen el derecho a ser informado como el nivel básico de participación, y señalan que una disposición oportuna y equitativa de información es lo que posibilita el proceso de comunicación, ven además a la información como un "peldaño indispensable para la distribución equitativa de las oportunidades de participación” (Dascal, 2002, p. 38).

Frente al derecho a opinar señalan que las personas deben tener la posibilidad de expresar sus problemas, intereses, y experiencias, siendo esto lo que les permite actuar y constituirse en comunidad (Dascal, 2007). La ciudadanía debe tener la posibilidad de "dar ideas, preguntar, sugerir, fiscalizar y protestar, eso es, entre otras cosas, una etapa superior de participación" (2007, p. 38).

La participación ciudadana se produce en la medida en que la comunidad tiene la posibilidad de estar informada y por lo tanto puede incidir en el manejo de los recursos públicos.

\section{Democracia participativa}

Partimos del concepto de participación propuesto por el Programa Andino de Derechos Humanos de la Universidad Simón Bolívar del Ecuador el cual señala que la participación es:

Interactuar, más o menos organizadamente, con quienes comparten ideales e intereses de vida para colaborar y enfrentar juntos eventuales resistencias, Sergio Micco define la participación política como la acción voluntaria de los ciudadanos en orden a elegir a sus representantes y a influir directa o indirectamente en las decisiones colectivizadas, aquellas que afectarán a todos en forma inescapable. ${ }^{8}$

8 Ver (https://goo.gl/tkFuxK), Universidad Simón Bolívar del Ecuador. 
La participación desde este estudio está vinculada a la idea de influencia, es conocido, por tanto, que la influencia se hace de forma organizada y en cuanto ciudadanos. Por lo tanto, la condición de ciudadano es la que le permite a la persona actuar en ámbitos políticos en una sociedad determinada.

Cunill (1991) señala que la democracia participativa supone la información, consulta, control e incluso decisión de la comunidad en directo sobre aspectos de las políticas públicas. Lo importante no son los mecanismos sino el fondo de la propuesta que consiste en la influencia real de la sociedad civil sobre la sociedad política.

En esto concuerdan tanto la LOTAIP como la autora antes mencionada. Para una verdadera democracia participativa es necesario que la ciudadanía asuma un rol y esto es posible solamente desde una comunicación efectiva y eficaz por parte de las entidades públicas.

Para que se dé una verdadera democracia participativa se requiere la interacción entre el Estado y la sociedad, interacción por la cual la sociedad civil penetra en el Estado. De esta manera la participación ciudadana tiene un rol protagónico que se verán reflejados a través de dos vertientes:

- Es un medio de socialización de la política.

- Es una forma de ampliar el campo de lo público hacía esfera de la sociedad civil y por ende de fortalecer a esta.

Es necesario que los gobiernos locales tengan como políticas de Estado brindar información de calidad a la ciudadanía para que esta pueda participar.

\section{Calidad de la información}

El periodismo es uno de los medios con mayor posibilidad de “aportar en la construcción de una sociedad más democrática y más humana.” Medranda (2017:73) para ello, las Nuevas Tecnologías de la Infor- 
mación y Comunicación (TICs) ofrecen múltiples y variadas herramientas para crear puentes entre las administraciones públicas y la ciudadanía.

De esta manera, La información puesta a disposición de la sociedad civil por parte del organismo público debe cumplir con los criterios de humanizar la información, es decir, tomar en cuenta a los ciudadanos, dar una información completa y transparente, una información con memoria y contextualizada, que sea contrastada y contrastable y que responda a un periodismo inteligible y comprensible (Moreno, Molina, y Corcoy, 2013, p. 797). Con estos criterios se puede discernir la veracidad de la información que se publica en un medio, sea este digital, escrito o visual. También es la norma que mide la calidad de información que utiliza ese organismo. Por lo tanto, es deber de la autoridad esforzarse por obtener un grado adecuado de cumplimiento de cada uno de los atributos mencionados.

El paradigma actual de Calidad de la Información (IQ) juzga el valor de la información según cuatro categorías: la disponibilidad, la presentación, el contexto y lo intrínseco. Cada categoría puede ser descompuesta en una serie de dimensiones de estudio (Wang \& Strong, 1996).

Arnauda Sequera (1999) define la norma ISO 9000 como "Conjunto de normas y directrices de calidad que se deben llevar a cabo en un proceso."

La calidad es, por tanto, el resultado del proceso de producción de un bien o servicio para cumplir con los requisitos y expectativas. Por tanto, hay que examinar cuál es el proceso de producción de la información y la comunicación que se publica en las webs.

\section{Caso de estudio}

En España, el proyecto Infoparticipa ha logrado conseguir mejoras en las prácticas de la publicación de información a través del proyecto Mapa Infoparticipa que ha sido aplicado a todos los ayuntamientos de este país. 


\section{0}

\section{Infoparticipa en Cataluña}

El equipo de Infoparticipa ha logrado conseguir mejoras en los ayuntamientos de Cataluña. En una primera oleada de evaluaciones de las webs municipales de Cataluña "sólo una parte muy reducida obtiene el color verde porque han superado el 50\% de indicadores positivos" (Moreno, Molina, y Corcoy, 2013, p. 515). Tal y como puede apreciarse en la tabla siguiente con los resultados a fecha 21 de marzo de 2013.

Tabla 1

Resumen de los datos representados en el Mapa

de las Buenas Prácticas de la Comunicación Pública Local en Cataluña

\begin{tabular}{|l|l|l|l|l|l|}
\hline $\begin{array}{c}\mathbf{N}^{\circ} \text { de } \\
\text { municipios }\end{array}$ & $\mathbf{N}^{\circ}$ habitantes & $\begin{array}{c}\text { Webs con } \\
\text { más del 50\% } \\
\text { de indicado- } \\
\text { res positivos }\end{array}$ & $\begin{array}{c}\text { Webs entre } \\
\text { 25\% } \mathbf{5 0 \%} \\
\text { indicadores } \\
\text { positivos }\end{array}$ & $\begin{array}{c}\text { Webs con } \\
\text { menos de 25\% } \\
\text { indicadores } \\
\text { positivos }\end{array}$ & $\begin{array}{l}\text { Sin web } \\
\text { / datos }\end{array}$ \\
\hline 10 & Más de 100000 & 10 & - & - & - \\
\hline 13 & $\begin{array}{l}\text { De } 50001 \text { a } \\
100000\end{array}$ & 12 & 1 & - & - \\
\hline 40 & $\begin{array}{l}\text { De } 20001 \text { a } \\
50000\end{array}$ & 19 & 21 & - & - \\
\hline 58 & $\begin{array}{l}\text { De } 10001 \text { a } \\
20000\end{array}$ & 13 & 43 & 2 & - \\
\hline 88 & $\begin{array}{l}\text { De } 5001 \text { a } \\
1000\end{array}$ & 7 & 70 & 11 & - \\
\hline 259 & De 1001 a 5000 & 2 & 75 & 182 & - \\
\hline 151 & De 501 a 1000 & - & 11 & 139 & 1 \\
\hline 303 & De 101 a 500 & 1 & 5 & 294 & 3 \\
\hline 25 & De menos de 100 & - & - & 21 & 649 \\
\hline 947 & & 64 & 226 & 649 & 8 \\
\hline
\end{tabular}

Elaboración propia a partir de los datos del Mapa Infoparticipa (2013) (www.labcompublica.info)

Sin embargo, en el mismo texto se destaca que estos resultados ya suponen una mejora comparando los datos del primer análisis con los del cierre de la oleada tanto al considerar el número de webs que supe- 
ran el 50\% de indicadores positivos como analizando el grado de cumplimiento con indicadores preferentes. Esto es así porque "este Mapa se ha convertido también en una guía que ha colaborado a mejorar la información de las webs de los ayuntamientos" (Moreno, Molina, y Corcoy, 2013, p. 524).

Esta experiencia es la que nos motiva a realizar este trabajo investigativo donde aplicaremos la metodología de Infoparticipa, con el afán, de lograr cambios significativos en las administraciones municipales del Ecuador.

\section{La metodología: indicadores obligatorios y voluntarios}

Esta metodología consta de una serie de indicadores que son pieza clave de la investigación, están en relación con la Constitución y la legislación española vigente. La investigación busca evidenciar en qué medida, a través de las páginas web, la ciudadanía se dispone de "información cualificada sobre el funcionamiento del sistema democrático, sobre las personas que han sido elegidas para gestionarlo, y sobre cómo trabajan y gestionan los recursos de la colectividad en beneficio de todos" (Moreno, Molina, y Corcoy, 2013, p. 508). Para ello, los indicadores se encuentran organizados en cuatro grupos de preguntas:

- Quiénes son los representantes políticos.

- Cómo gestionan los recursos colectivos esos representantes políticos.

- Cómo informan sobre la gestión de los recursos colectivos.

- Qué recursos y herramientas ofrecen para la participación ciudadana. (Los indicadores en detalle se anexarán al presente trabajo).

Para el caso ecuatoriano, la metodología ha sido adaptada de acuerdo con las normativas local, respondiendo particularmente a las exigencias de la Ley Orgánica de Transparencia y Acceso a la Información Pública (LOTAIP), Ley Orgánica de Participación Ciudadana (LOPC), 


\section{2}

El Código Orgánico Organización Territorial Autonomía y Descentralización (COOTAD) y la Ley Orgánica de Comunicación (LOC).

En este sentido, se construyeron 53 indicares de evaluación, unos obligatorios que son tomados literalmente de las leyes antes mencionadas y otros voluntarios que responden la exigencia de información que se considera necesaria para la participación ciudadana.

\section{Mapa 1}

Distribución geográfica del Ecuador

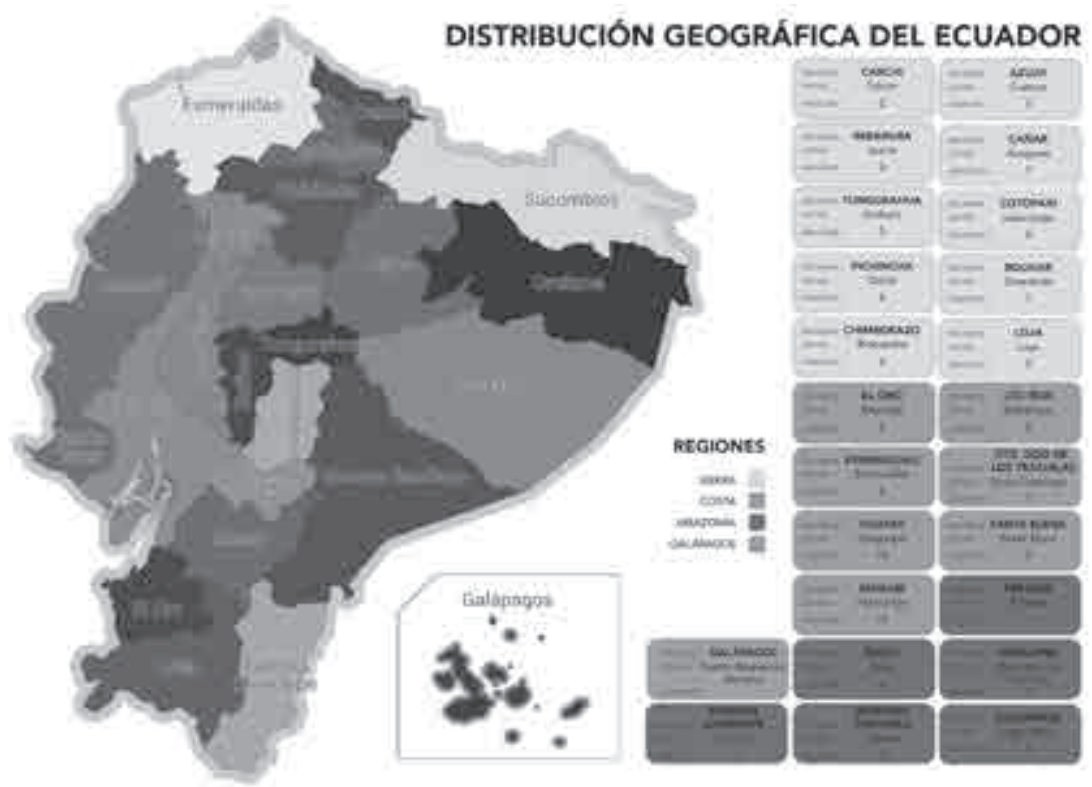

Elaboración: Narcisa Medranda

La evaluación se la aplicó a 82 municipios con más de 25000 habitantes y 24 municipios que son capitales de provincia

Con la evaluación se buscó en primer lugar, auditar la información que se publica en los portales web de los municipios ecuatorianos $y$, en segundo lugar, establecer mecanismos de acompañamiento me- 


\section{3}

todológico que permita mejorar las practicas comunicaciones en estas instituciones públicas.

Los resultados obtenidos de la primera evaluación arrojaron que 1 de 106 municipios superó el 50\% de los indicadores establecidos (Guayaquil con 63.38\%), mientras que 56 de 106 alcanzaron entre 25 y $49 \%$ y 49 de 106 no superaron el 25\%. Los resultados se pueden visibilizar de la siguiente manera: el color blanco, los municipios que no pasaron el $25 \%$, color amarillo aquellos municipios que alcanzaron entre 25 y $49 \%$ y en color verde, los municipios con más de $50 \%$.

Resultados visibles de la primera evaluación

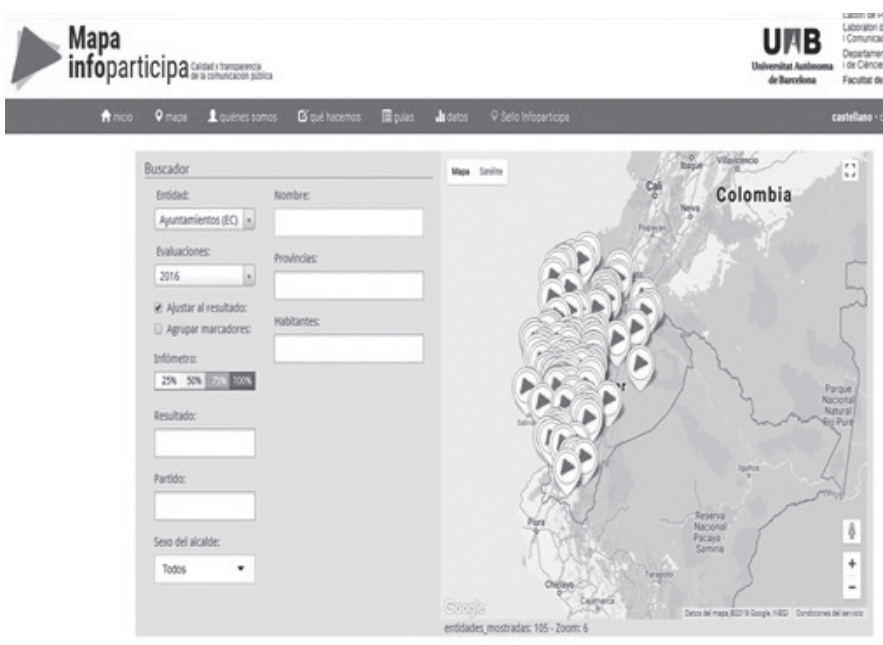

Fotografía de los resultados visibles en el Mapa Infoparticipa por colores, evaluación 2016

\section{Conclusiones}

La investigación visibilizó que la normativa ecuatoriana es muy rigurosa en temas de acceso a la información pública y participación ciudadana. La Ley Orgánica de Transparencia y Acceso a la Información 


\section{4}

Pública estipula claramente qué, cómo y dónde se debe publicar la información pública.

La revisión del marco legal confirma que la normativa ecuatoriana garantiza la difusión de la información pública y el acceso a la misma, sin embargo, las instituciones públicas hacen caso omiso de tal normativa. Por este motivo, en la primera evolución, las webs municipales no alcanzan el 50\% de transparencia en temas de publicación de la información generada en estas instituciones.

\section{Bibliografía}

Arruda, Furtado et al. (2010). La importancia del control social en la supervisión del gasto público. Reason Magazine, Contabilidad y Finanzas, 1. Editorial Fortaleza.

Briano, G. (2012). Factores institucionales que inciden en la transparencia del gobierno corporativo: un estudio en empresas cotizadas latinoamericanas. Disertación (Doctorado Ciencias Económicas y Empresariales). Departamento de Administración de Empresas de la Universidad de Cantabria. Santander-España.

Canavaggio, P. (2011). El acceso a la información pública en el mundo. Un derecho humano emergente. En VII Seminario Internacional de Archivos de Tradición Ibérica. Río de Janeiro, Brasil.

Constitución de la República del Ecuador (2008). Registro Oficial 449, Asamblea Nacional, Montecristi: Ecuador.

Cunill, N. (1991). Participación ciudadana. Dilemas y perspectivas para la democratización de los Estados latinoamericanos. Centro Latinoamericano de Administración para el Desarrollo CLAD - Caracas

Dascal, Guillermo (2007). Los espacios públicos y el capital social: aportes para comprender la relación entre ambos conceptos. Cuadernos de Geografía - Revista Colombiana de Geografía, 35-38. Obtenido de https://goo. gl/NzaWMQ (5 de agosto de 2018). ISSN 0121-215X

De León, P. (2008). Hacia un concepto de transparencia: orígenes e importancia. Obtenido de https://goo.gl/5gWWUT (12-07-2017).

Escobar, G. (Dir.) (2015). Transparencia e Información Pública, XIII Informe de la FIO (Federación Iberoamericana de Ombudsman). Madrid, España: Trama Editorial. 


\section{5}

Bellver, A. \& Kaufmann, D (2005). Transparenting Transparency: Initial Empirics and Policy Applications. http://dx.doi.org/10.2139/ssrn.808664

Briano Turrent, G. del C. (2012). Factores institucionales que inciden en la transparencia del gobierno corporativo: un estudio en empresas cotizadas latinoamericanas. Disertación (Doctorado Ciencias Económicas y Empresariales). Departamento de Administración de Empresas de la Universidad de Cantabria. Santander-España.

INFOPARTICIP@, (2013). Obtenido de https://goo.gl/iyDtBj (10 jun. 2014). Ley Orgánica de Transparencia y Acceso a la Información Pública (2004). Registro Oficial Suplemento 337, Congreso Nacional, Quito: Ecuador.

Machado, V. (2014). Fatores explicativos do nível de evidenciação nas páginas eletrônicas de municípios do sul do Brasil. Disertación (Mestrado em ciências Contábeis)- Posgraduación en Ciencias Contables de la Universidade do Vale do Rio dos Sinos - UNISINOS. Porto Alegre, Brasil.

Medranda, N. (2017) Calidad y transparencia en la información y comunicación que se emite a través de las páginas webs de los Municipios: Comparación de caso Ecuador y España. (tesis doctoral) Universidad Autónoma de Barcelona, España. Obtenido de https://goo.gl/SfoLi8

Moreno, A., Molina, P. \& Corcoy, M. (2013). La información de las administraciones públicas locales. Las webs de los ayuntamientos de Cataluña. Revista. Latina de Comunicación Social 68. DOI: 10.4185/RLCS-2013987, pp. 502-528.

Organización de los Estados Americanos (2000). Declaración de Principios sobre la Libertad de Expresión. Obtenido de https://goo.gl/HHvTqk (12-07-2017).

Piotrowski, S. (2010). Transparency and Secrecy. A Reader Linking Literature and Contemporary Debate. London: Lexington Books.

Puga, J. (2014). Government Transparency: Impacts and Unintended Consequences. Gestión y política pública, 23(2), 512-519. Obtenido de https://goo.gl/vSXLHD (12-07-2017).

Sandoval, R. (2015). Gobierno abierto y transparencia: construyendo un marco conceptual. Convergencia, 22(68), 203-227. Obtenido de https://goo. gl/PeXEXh (05-08- 2018).

Solimano, A., Tanzi, V. \& Del Solar, F. (2008). Las termitas del Estado: ensayos sobre corrupción, transparencias y desarrollo. Fondo de Cultura Económica.

Sousa, J. (2010). La experiencia de Chile en la transparencia y acceso a la información: el cambio institucional del gobierno central ante las nuevas 


\section{6}

disposiciones normativas, dirigida por el doctor Álvaro Vásquez Valdivia. Santiago de Chile. Obtenido de https://goo.gl/9KvaJ3

Swing, J. (2009). Gobiernos Autónomos Descentralizados. Universidad Técnica Particular de Loja-Ecuador: Editorial CEP.

UNESCO (2012). Libertad de información en América Latina y el Caribe. Obtenido de https://goo.gl/ry4T7r (12-07- 2017).

Wang, R. \& Strong, D. (1996). Beyond Accuracy: What Data Quality Means to Data Consumers. Journal of Management Information Systems, 12(4), 5-33. Obtenido de https://goo.gl/cTwriN 


\section{Segunda Parte \\ Identidad, representación y medios}





\section{Capítulo 3 Representación de la identidad adolescente mediante imágenes de Facebook}

Nina Aguiar Mariño

Paula Castelo Ortiz

\section{Resumen}

El sujeto comunicacional contemporáneo recrea su identidad así como los significados sociales de su contexto a través de redes sociales digitales. En Facebook, los jóvenes usuarios acceden a un zapping visual con las fotografías que publican sus amigos. Sus características pueden ser agregadas para la representación de identidades entre pares. ¿Cómo es que los usuarios entre 13 y 15 años de edad representan su identidad mediante las fotografías que publican en Facebook? Mediante la interacción simbólica en esta red social se crean y recrean estéticas de representación en un espacio aparentemente seguro para que los jóvenes intenten diversas identidades. Para ellos no existe continuidad entre el mundo fuera de línea y en línea, pero sus fotos representan su identidad en la web y pasan a ser lineamientos para crear su identidad fuera de la web. Aunque los usuarios no consideren que en la web se presentan quienes son, al ser parte de Facebook acceden a signos que adoptan para reconocerse entre pares internautas y manifestar quienes son desde la diferenciación pero también desde la similitud.

\section{Introducción}

Las tecnologías y el internet en el siglo XXI, han abierto diversas posibilidades para la construcción de identidades de los usuarios jóvenes. No es que ellos se vean influenciados o manipulados de forma directa por un ser invisible identificado como World Wide Web. Tampoco significa que los adultos sean completamente ajenos a este fenómeno.

El World Wide Web, mundo digital, atrajo en la última década del siglo XX, a varios investigadores de diferentes disciplinas. Los investigadores se enfocaron principalmente en los usuarios de MUD (Multi User 


\section{0}

Dungeon), un videojuego de rol en línea ejecutado en un servidor. En estos juegos el usuario se representaba en avatares construidos a partir de un catálogo de características físicas como el color de ojos, la contextura y otros rasgos. Manovich (1998) y Turkle (1998) observaron que en los MUD sus usuarios construían una identidad en línea a partir de lo que el software ofrecía. Permitía que los usuarios se representaran en varios avatares con los cuales experimentaban personalidades, géneros y apariencias diferentes.

En el siglo XXI participar en este tipo de juegos ya no está en auge. Lo que está en auge es formar parte de las redes sociales. La identidad en línea, como se representaba en los MUD, no ha desaparecido, y se manifiesta en las comunidades virtuales. Los representantes del exitoso negocio de las plataformas virtuales comprenden que no se puede desvincular de Internet a los jóvenes, potenciales usuarios, y por ello, disminuyen las restricciones de edad para que puedan unirse. Algunas comunidades virtuales hasta permiten que personas de cualquier edad se suscriban, aunque otras delimitan una edad mínima para crear una cuenta como usuario. Facebook por ejemplo, establece que la edad mínima para ser usuario es de 13 años. En la práctica un menor puede adulterar su año de nacimiento y como Facebook no dispone de mecanismos para comprobarlo, existen varios usuarios menores.

Facebook, al igual que otras plataformas virtuales, permite interactuar y comunicarse con otros usuarios a nivel lingüístico y paralingüístico. La comunidad joven de esta década tiene, como en toda cultura, códigos y significados para relacionarse. Las fotografías son uno de sus códigos paralingüísticos mediante los cuales los jóvenes se identifican con sus amigos y pares en Facebook.

"La forma cómo un individuo presenta su cuerpo, las características de él y la moda al vestir es parte de la identidad" (Blúmer, 1982, p. 6). Esta parte de la identidad, que menciona Blúmer, la presentan los usuarios de Facebook a través de sus fotos y puede ser asumida superficialmente por los observadores como la totalidad de lo que es el 
sujeto. El inconveniente consiste en que la identidad concedida por el observador es a partir de una representación construida por quien se retrata en la foto. Habitualmente las imágenes que se publican en las redes como Facebook son aquellas que el usuario considera que no se ven mal, que no serán rechazadas, y, una manera de confirmarlo es recibir likes ${ }^{9}$. El aspecto que un usuario publica de sí mismo en Internet es una representación y no necesariamente su apariencia en la cotidianidad. Se podría decir que los retratos en Facebook presentan una identidad sesgada, y que esa característica constituiría una tendencia en las fotografías de perfil.

Ante esta situación surge la inquietud, ¿Cómo representan su identidad los usuarios entre 13 y 15 años de edad mediante las fotografías que publican en Facebook?

Para esta investigación es preciso comprender los parámetros por los que una fotografía de Facebook es apreciada por la comunidad. Se busca comprender la correlación de los retratos de Facebook con la identidad de los jóvenes como sujeto individual y como parte de la cultura de sus pares internautas. Para cumplir el objetivo central de esta investigación se propone determinar si existe concordancia entre cómo los usuarios quieren ser identificados y la imagen presentada.

Tomando en cuenta la apreciación de Vásquez quien manifiesta que para estudiar lo juvenil solo se lo puede hacer a partir de las condiciones materiales y simbólicas de su contexto. Es lo que permite a la identidad juvenil adquirir determinado sentido (Vásquez 2014, p.13). La presente investigación se enmarca en lo simbólico a partir de la lectura que los usuarios tienen sobre sus fotografías y las de sus pares. Se trata de una investigación de orden exploratorio sin clasificar los usuarios por su contexto socioeconómico.

9 Like: hace referencia a un botón interactivo de Facebook que en español es conocido como "Me gusta". Esta es una de las opciones de retroalimentación que un usuario puede tener ante una publicación de otro usuario de Facebook. 


\section{2}

¿Por qué se escogió Facebook y no otras redes como Instagram o Tumblr, donde también se interactúa mediante la publicación de fotografías? Aunque estas redes han aumentado su número de usuarios y están de moda en algunos países de Europa y en los Estados Unidos, no ocurre lo mismo en América Latina donde Facebook tiene una gran acogida entre los jóvenes.

El 32,5\% de los usuarios de Facebook en América Latina hasta el 2013, comprendían las edades entre 15 y 24 años. También en Ecuador Facebook tiene aún una gran acogida: 85000002 de usuarios hasta mayo del 2015. Ecuador se posicionó como el número 38 en el orden de los países con más usuarios en la red a nivel mundial.

Para Flores (2009) este tipo de redes son amplias y abarcan muchos ámbitos, pero principalmente cumplen el rol de contactar entre sí a los usuarios y visibilizarlos. En Facebook quien se muestra existe. Disminuirá el nivel de notoriedad de un usuario en la plataforma web, si deja de publicar fotografías o publica fotografías que a nadie le gustan, nadie da likes o nadie comenta. Según Flores "estar presente en redes sociales como Facebook, obliga a diseñar una identidad que sea aceptada por todos sus amigos y conocidos" (Flores, 2012, p. 86). Por ello, los usuarios manipulan las características de sus retratos así como su apariencia física, para lograr el fin último que es verse bien.

Según un estudio realizado en Colombia y España se demostró que los usuarios adolescentes de Facebook dedican la mayor parte de su tiempo a las fotografías que publican para ser identificados, por lo que diseñan, crean, o editan su imagen (Almansa, Fonseca y Castillo, 2013). En el estudio se pone en evidencia que en España y Colombia los chicos y chicas de 12 a 15 años compiten por subir fotos llamativas para sus compañeros de aula, para ello modelan determinadas poses, editan las imágenes para resaltar o eliminar características físicas, o realizan montajes (Almansa et al., 2013). 


\section{3}

Con inquietudes similares, el presente artículo pretende acercarse a los usuarios jóvenes para comprender los códigos sociales que guían las características de las fotos que suben a Facebook. ${ }^{10}$

Varios investigadores consideran que los jóvenes corren riesgos al sobreexponerse en sus fotos de redes sociales, pero los usuarios jóvenes hacen caso omiso de los espectadores extraños de su vida. Dillon realizó en Argentina otra investigación para abordar la representación de jóvenes de 17 y 18 en Facebook, y llegó a la conclusión de que "contra los diagnósticos que advierten sobre el fin de la intimidad, los adolescentes entrevistados se mostraron conscientes de la necesidad de controlar aquello que se hace público en Facebook" (2013, p. 25). Sin embargo, prevalece la importancia de subir una fotografía que les guste a sus amigos y reciba de cierta manera gratificaciones en línea por ella.

Para el Dr. Gregorio Pérez Bonet, psicólogo y sicoterapeuta, la red y las comunidades virtuales se ofrecen como un juguete para la personalidad de los jóvenes. Pérez aseguró que las redes virtuales "se convierten en una ventana para asomarse a un mundo infinito de máscaras que le brinda la imaginación y el anonimato de la red, junto a su deseo febril de independencia" (Pérez, 2010, sección de conclusiones, párrafo 1). Por ello considera que las comunidades virtuales son laboratorios de pruebas donde se puede ensayar la construcción de la identidad personal, lo cual implica riesgos como varios tipos de acoso. El acoso puede originarse incluso por no tener fotos como aquellas en tendencia o por tener fotos donde la intimidad se transgrede para obtener más likes.

Tras otra investigación realizada en Argentina en el 2013 se observó que la representación del usuario joven en Facebook se enfoca en lo que este consume, su imagen para ser aceptada y popular debe mostrar visitas a lugares de estatus, ropa de catálogo y actividades extra curriculares que generan admiración en sus pares (Moreno, 2013). En ese trabajo el autor afirma que:

10 Información obtenida el 11 de mayo de 2015 en https://goo.gl/Pa3R6M 


\section{4}

Una característica central del éxito en el mantenimiento de la imagen en Facebook es la capacidad del sujeto para redefinirse, reinventarse para ser admirado por sí mismo y por otros. La identidad se convierte en un atributo del momento, una condición dinámica (Moreno, 2013, p. 5).

La imagen que el usuario presenta de sí mismo, sus poses, su ropa, su apariencia en general debe ser la mejor para agradar dentro de los parámetros sociales de la red, aunque la misma apariencia en un contexto diferente, en la calle o colegio puede ser valorada de forma diferente. La interacción social tiene códigos que generalmente las personas respetan para no desencajar, así la vestimenta que se lleva para ir a la discoteca es diferente a la de una tarde deportiva o una reunión con la familia. La apariencia física en el contexto de Facebook, no necesariamente es valorada de la misma manera fuera de esta red.

La gran cantidad de redes sociales permiten que los jóvenes y niños de los rincones más alejados del Ecuador accedan a las tendencias y modas. El estilo de vestimenta, maquillaje, peinados y accesorios (incluyendo tatuajes y aretes) que cada generación lleva durante su adolescencia se relaciona con su contexto sociocultural y es influenciado por la industria. La apariencia física es parte de la auto aceptación y de la aceptación del grupo social al que un individuo pertenece (Cuesta, 2000), por ello difícilmente los jóvenes salen de los esquemas de auto representación que rigen mediante la industria cultural.

La ilusión de ser famoso, aunque en un pequeño círculo social, puede impulsar a los jóvenes a que imiten el tipo de fotografías que a otros usuarios de Facebook les funciona para tener gran cantidad de comentarios o likes. Las fotografías subidas a la web son una presentación para los demás, pero "la realidad corporal es también una realidad subjetiva, una vivencia impregnada de memorias y de expectativas, resultantes de la continua dialéctica cuerpo/mundo" (Von Doellinger, 2011, p. 45). Las características que representa un sujeto mediante su cuerpo no son solo las biológicas, el cuerpo se construye de acuerdo con 


\section{5}

la "danza diaria" que el individuo debe practicar con el entramado social del mundo por el hecho de convivir con otros individuos.

Debido al auge de internet han cambiado el entramado social y la forma de socializar. La presentación del cuerpo de la actual generación colegial es diferente a la generación de hace diez o quince años. Es posible que por la interactividad en Facebook se estructuren patrones fotográficos para que el sujeto sea parte de la "sociedad informática" joven. Esas características fotográficas al tener la función de gustar a los otros puede que no coincida con los gustos de quien se ha retratado, que el usuario no se identifique con esa foto.

Laplanche y Pontalis tras una investigación consideraron que "la construcción de la identidad, el sentido que tiene todo ser humano de sí mismo, requiere en un primer momento de identificar a los objetos del mundo que son introyectados desde esta identificación puede entonces el sujeto identificarse". Si un usuario entre 13 y 15 años de edad interactúa gran cantidad de su tiempo en Facebook observando fotografías que se replican de otros usuarios y estos a la vez de otros, esas imágenes cumplen el rol del objeto que exponen Laplanche y Pontalis y serían entonces introyectadas, influyendo en la imagen que el sujeto construye de sí mismo, una parte de su identidad (Laplanche y Pontalis 1996 en Fuentes s.f., párr. 3).

\section{Metodología}

Este trabajo se realizó mediante un estudio exploratorio para obtener un conocimiento más amplio respecto al tema e investigar aspectos que no se han profundizado en otras investigaciones latinoamericanas. Si bien se han realizado previamente indagaciones sobre el uso que los jóvenes dan a Facebook y cómo se representan en la red, las fotografías no han sido estudiadas como constructores de identidad. Se ha investigado que los jóvenes en las redes sociales, representan en avatares la modificación de su cuerpo y look para fotografiarse, los factores 


\section{6}

que determinan qué foto publicar o cómo la imagen de la vida cotidiana pasa a presentarse en la red. Esta investigación se propuso conocer si los usuarios jóvenes proyectan en sus fotos su identidad y su nivel de satisfacción de cómo se presentan con la manera en que quieren ser identificados por su mundo social.

Por ello, la investigación fue también descriptiva para medir las variables del tema y la concordancia que el retrato tiene con la representación de identidad individual. El enfoque descriptivo, como el término induce a pensar, describe lo que el investigador percibe durante la observación con el grupo focal, lo que permite conocerlo y determinar el juego de características que lo hacen presentarse en la web de manera determinada.

La etnometodología como método de investigación guio este artículo por su propuesta de análisis del discurso y por el valor que da a la semiótica para entender desde la comunicación paralingüística a la situación, en este caso la representación de identidad en Facebook. Firth afirma que "la etnometodología está interesada en la acción social, la intersubjetividad, y la comunicación lingüística” (2010, p. 589), esta se interesa por las prácticas cotidianas que un grupo llega a dar por sentado. Estas actividades de un sujeto y un grupo coordinan su comportamiento diario, crean y sostienen el orden social (Firth, 2010).

La comunicación fue el esqueleto para indagar la representación desde la plataforma comunicacional del grupo de estudio. "La comunicación más que una ciencia, es un proceso que aparece tanto en los niveles cognoscitivos del individuo como en su acción social" (Moragas en Lozano, 2007, p. 2). Entender desde este punto de vista la comunicación ayudó a comprender el problema desde las realidades virtuales entremezcladas con las construcciones sociales.

La línea comunicacional que dirigió este ensayo es la interpretacionista, que ha ido tomando auge las últimas décadas en la investigación de la comunicación. Su preocupación central según Deacon, Pickering, Golding y Murdock es "la exploración de las formas en que la gente 


\section{7}

da sentido a sus mundos sociales y como expresa esos entendimientos a través de lenguaje, imaginarios, rituales sociales" (Lozano, 2007), entre otros. Para los interpretacionistas las estructuras de la vida social cambian constantemente, por lo que su objetivo es entender cómo la gente da significado a su mundo y para ello los investigadores deben interpretar desde el punto de vista de los actores de cada situación social para entenderla.

La investigación desde la perspectiva interpretacionista permite comprender a los usuarios de 13 a 15 años y su mundo simbólico dentro de Facebook, así como el lenguaje de la fotografía dramatizada que deja de capturar el momento y captura una persona o situación programada. El interpretacionismo se enfoca en la exploración de los mundos sociales personales, de su expresión en torno al lenguaje, el significado y el significante. El enfoque interpretacionista se apoya en el interaccionismo simbólico y la ya mencionada etnometodología.

El interaccionismo simbólico fue tomado como línea teórica comunicacional, que desde la perspectiva de uno de sus principales exponentes, postula que el significado de algo procede de la interacción de un individuo con otros. De igual forma propone que las personas actúan sobre la base del significado que atribuye a los objetos y situaciones e intenta comprender el proceso de asignación de símbolos con significado al lenguaje hablado o escrito y al comportamiento en la interacción social (Blumer, 1982, p. 8).

En el interaccionismo simbólico se requiere que el investigador entre activamente en el mundo de las personas que está estudiando. La observación del grupo focal y las charlas ayudaron en esta investigación a conocer la situación desde el actor. Se pudo observar e interpretar lo que el usuario joven tiene en cuenta para plasmarse en un retrato fotográfico.

La etnometodología, como método de investigación busca entender cómo se llega a vivir sin cuestionar la vida cotidiana, su preocupa- 


\section{8}

ción es identificar las reglas que la gente aplica para que su mundo tenga sentido. Para conseguirlo se sustenta en el análisis del discurso y toma como prioridad para ello la semiótica.

La etnometodología guio la exploración en el ámbito de la paralingüística implícita como parte de lo que los adolescentes comunican mediante sus retratos y lo que perciben al mismo tiempo de los retratos de sus pares.

Para comprender la comunicación paralingüística es necesario tener en cuenta que el lenguaje verbal o escrito esté sobreentendido en la cotidianidad como lenguaje, pero también lo está en cualquier imagen producida, cuando se usa para expresar un sentido. "Otras cosas que no son 'lingüísticas' en el sentido ordinario también son lenguaje: el 'lenguaje' de las expresiones faciales o de los gestos, por ejemplo, o el 'lenguaje' de la moda, del vestido" (Hall, 1997, p. 16). Para Hall, sonidos, imágenes tanto como palabras sirven como un signo que toma sentido al insertarse con otros signos en un sistema. Por ello afirma que la existencia de lenguajes comunes permite traducir los pensamientos en palabras, sonidos o imágenes y usarlos para comunicar nuestros pensamientos.

Para interpretar los signos paralingüísticos observados en los retratos de los jóvenes en Facebook, también se abordaron principalmente las propuestas de Stuart Hall. Para Hall (1997) todo lenguaje se manifiesta al compartir códigos, lo que ocurre al pertenecer a una cultura. Los códigos establecen una relación entre nuestro sistema de lenguaje y nuestras concepciones del mundo. El proceso genera un sistema de representación que construye el sentido para que las formas de comunicarse sean las determinadas y no otras. Somos nosotros los que fijamos el sentido social de manera tan firme que, después de cierto tiempo, parece ser una cosa natural e inevitable. El mismo autor previene que las convenciones sociales y lingüísticas cambian a lo largo del tiempo. 


\section{9}

Como parte de las técnicas aplicables en la etnometodología se realizó la observación y monitoreo de las fotografías de Facebook de diez representantes del grupo de muestra, para conocer las variables relevantes de la construcción social de las representaciones fotográficas de los colegiales. Se realizaron también entrevistas semiestructuradas a los mismos usuarios. También se realizaron entrevistas a tres profesionales en el área de la sicología, sociología y comunicación dado que para una investigación en el área de comunicación es importante su relación con las ciencias sociales.

Las 67 encuestas diseñadas y realizadas se utilizaron para conocer si las entrevistas al grupo de muestra reflejaban lo que el resto de compañeros consideraba. En el proceso de investigación se efectuaron grupos focales con todos los usuarios del caso de estudio. También se realizó una reunión previa a la investigación para contextualizar su cercanía con el tema y seleccionar el grupo de muestra para la observación y entrevistas. En otra reunión se recogió información mediante la observación participante en un taller aplicado bajo la técnica "Teatro del Oprimido" para conocer sus percepciones sobre diversas situaciones comunes de Facebook. Esta reunión también sirvió para informar a los jóvenes las observaciones realizadas durante la investigación y escuchar las reflexiones del grupo focal tras la exposición. Tanto las encuestas como el taller se basaron en las respuestas de las entrevistas y de la observación de los perfiles.

Entender desde la visión de los adolescentes los motivos de sus fotografías implicó observarlas desde una perspectiva menos sesgada y prejuiciada. En la investigación no se pretendió juzgar o catalogar a los jóvenes por ciertas prácticas y representaciones en Facebook. La realización de reuniones tuvo el objetivo de que los jóvenes puedan compartir sus visiones sobre la interacción en la red.

Es importante aclarar que, la disposición y transformación de los datos para la construcción de los resultados, se logró también, con el manejo de métodos y técnicas cuantitativas. El análisis de contenido 


\section{0}

como método y técnica del enfoque cuantitativo, es un procedimiento sistemático, que permitió examinar la información de 67 perfiles escogidos en Facebook. Se elaboró una plantilla con los datos de los perfiles, y se contemplaron las distintas variables de las fotografías compartidas en la red; el ejercicio de aplicación se llevó a cabo de manera ordenada, en el proceso de observación.

Los principales aspectos que se tomaron en cuenta fueron: la frecuencia en la publicación de las fotografías, las prácticas recurrentes mostradas en las mismas, y los planos fotográficos, resaltando ciertas partes del cuerpo. Las dos últimas características se valoraron como interesantes o no interesantes para el grupo focal, según la cantidad de comentarios y likes que recibieron las fotos.

No se consideró como fundamental cuantificar las opiniones de los usuarios, sino conocer sus percepciones.

Los temas que se abordaron en las entrevistas a los jóvenes tuvieron como objetivo los siguientes aspectos: i) Conocer los motivos de retratarse en Facebook con determinadas poses. ii) La aceptación de esas estructuras fotográficas al verlas en los perfiles de sus amigos. iii) La aceptación offline de esas características con que ellos y sus amigos se presentan en Facebook.

Para conocer diversas opiniones se realizaron entrevistas a profesionales en psicología (Tenorio, 2015), en sociología (Vásquez, 2015) y en comunicación (Suriaga, 2015). Para complementar y contrastar la información se revisaron ensayos científicos y publicaciones realizadas en América sobre la construcción de la identidad de los jóvenes mediante el uso de Facebook publicadas desde el 2010.

La etnografía a pesar de ser un método recurrente en la investigación cualitativa y ser aplicada en las investigaciones de comunicación y antropología, sirvió durante el proceso para aplicar los instrumentos de recolección de información como la observación participante y las notas de campo obtenidas en el proceso de observación de perfiles. 


\section{Resultados}

\section{Me gusta-no me gusta. Parámetros de las fotos destacadas}

"Me tomo varias fotos y les pregunto a mis amigos ¿cuál les gusta? y esa la subo de perfil" (Informante C., 2015).

Las fotos que tienen más likes se asumen generalmente como las más destacadas, el 75\% de los encuestados otorgan likes cuando la persona en la fotografía se ve atractiva, guapa o sexi. Desde el interaccionismo simbólico, los significados son configurados desde las relaciones humanas a partir de un proceso donde, como explica Blumer (1982, p. 5), el significado de un objeto ${ }^{11}$ para un individuo es el resultado de cómo actúan hacia ese objeto las personas con las que se relaciona el individuo. Para el grupo, si una foto tiene likes significa que es aceptada, y de cierta forma significa también que ellos son aceptados. La foto de perfil del joven usuario adquiere gran valor al ser reconocida con likes por sus contemporáneos porque en Facebook los amigos otorgan significado a la existencia de una foto. Hay alguien que mira y aprueba la fotografía.

La importancia que se otorga a los likes de las fotos de perfil se sustenta en el proceso de interacción que brinda Facebook. El individuo no acepta por ósmosis los significados sociales. "Los significados desempeñan su papel en el acto a través de un proceso de auto interacción" (Blumer, 1982, p. 4). Mientras los jóvenes observan las fotos de la Red retienen información social que forma parte de una auto-comunicación que contornea y define cómo serán sus fotografías y cuáles colgarán como foto de perfil. Los likes o comentarios sobre la foto permiten conocer la circunferencia que delimita que tipo de retratos recibirán más likes.

Los gustos siempre serán misteriosos, son variables para cada persona y son variables también con el paso del tiempo y al cambiar el

11 Desde el interaccionismo simbólico se comprende al objeto como todo aquello que puede ser señalada y hacer referencia, siendo así por ejemplo una silla, una persona, un ideal. 


\section{2}

contexto. Para el grupo investigado los gustos de la mayoría de sus pares difiere de sus propios gustos al valorar una fotografía en la red.

Al pensar en el tipo de fotos que comúnmente reciben más likes por otros jóvenes de su edad, los informantes clave consideran que son fotos, en las que quien se retrata usa poca ropa o prendas pequeñas dejando ver la musculatura de abdomen y brazos en el caso de los hombres, y resaltando la cintura, nalgas y pecho en las mujeres. Para ellos estas características en una foto significan posar excesivamente y cuando se convierte en recurrente constituye motivo de burla y crítica en el grupo. El 49\% de los encuestados afirman rechazar las fotografías de Facebook donde se muestran de forma excesiva. Los entrevistados explican que este tipo de fotos es sobre todo recurrente en sectores populares, de bajo nivel socioeconómico y para ellos raya en lo vulgar, porque apela a lo sexual. Sin embargo más de la mitad de los entrevistados afirma que en algún momento han subido fotos con estas características en su perfil.

El 100\% de los entrevistados afirman que vestir "a la moda" en las fotos aumenta la posibilidad de tener likes, y la aceptación y reconocimiento de sus pares pasa del retrato a la persona. Basta que unas pocas personas del grupo tengan fotografías vistiendo a la moda para que se constituya en un parámetro de belleza y aceptación. Se evidencia el postulado de Blumer (1982) de cómo el individuo realiza un proceso de selección, verificación y análisis del actuar del otro hacia el objeto, llevándole a un proceso de comunicación consigo mismo formando su accionar en torno a los significados de los otros (p.25). Según Blumer para unificar los actos individuales se determina primero el acto social con el cual los sujetos van a comprometerse y segundo procesando los actos de otros al formar una acción conjunta (1982, p. 26).

Modelar la ropa en los retratos no es todo, los hombres consideran que las fotos del sexo opuesto reciben likes, porque físicamente son bonitas, tienen un rostro tierno, y se maquillan sin exceso. Cerca del $40 \%$ valora las fotografías donde el retratado se muestra divirtiéndose. El grupo considera que las fotos deben mostrar a alguien que se divierte, 
lo que se visualiza al retratarse con amigos y al hacer expresiones gestuales o sonreír aunque no se realice ninguna actividad en particular. No importa lo que hagas, en menor medida donde estés, lo que importa es como te ves y debes verte feliz.

Fotografiarse para Facebook resulta algo estratégico, algo pensado, algo diseñado. Gracias a la digitalización esto se puede conseguir al seleccionar la mejor de entre numerosas fotos tomadas en privado, por ejemplo en la habitación del joven. El adolescente se arregla, se prepara para su sesión de fotos privada. Se maquilla, se alista, puede cambiar de atuendos en cada foto. Se prepara no para salir a interactuar con otras personas sino para interactuar con la cámara de fotos y más tarde, con los usuarios de la red.

\section{Facebook, un espacio para construir variables}

Según el sociólogo Vásquez la identidad es algo que integra o constituye al sujeto, lo que le da seguridad. En las nuevas tecnologías como Facebook los usuarios se representan mediante un discurso gráfico, la identidad es una construcción con base en un relato autobiográfico. Para la construcción de este relato el usuario "tiene la capacidad de negociar con los recursos simbólicos” a su alcance (Vásquez, 2015). Por ello el sociólogo considera que la identidad como forma de diferenciarse no es radical, y que un individuo puede homogeneizarse sin necesidad de anular su identidad, todo va acorde a las necesidades y circunstancia por las que el sujeto atraviesa.

Mediante las fotos de Facebook se coquetea. Uno de los objetivos es verse bien para el sexo por el cual se siente atracción y además para alcanzar reconocimiento entre los amigos, por su apariencia, afirman todos los encuestados. El coqueteo es el medio para tener más likes, ser reconocido en la red y aumentar el número de amigos virtuales. Para lograrlo el usuario no se debe mostrar en la red necesariamente como es en la vida cotidiana. Una foto retocada digitalmente ${ }^{12}$ no se considera

12 Por lo general se aplican filtros de color o se juega con la luz y sombras. Los editores de fotos permiten ajustar el brillo y contraste, la saturación y temperatura 
un falso reflejo del sujeto retratado y es aceptada; lo importante es que se vea bien. Uno de los informantes que tiene muchos likes y que según sus compañeros de clase "tiene fotos muy bonitas", afirma: "Facebook solo es para pasar el tiempo y subir fotos, no muestra quien eres en realidad” (Informante D., 2015)

Facebook es un espacio donde se representa un ideal de lo que el usuario quisiera ser. Según el psicólogo Tenorio, uno de los entrevistados, Facebook para las nuevas generaciones es un espacio de construcción de identidades. Estas identidades se construyen formando un relato visual a la par en el mundo offline y online, unificados durante el proceso de representación identitaria, porque permite extender el ámbito de interacción con otras personas. Del mismo modo el entrevistado señala que la identidad antiguamente se comprendía de manera doméstica y que ahora es más social "el sujeto se hace mediante las fotos que publica, pero también mediante las fotos de mis contemporáneos mayores a medida de las pautas que me das" (Tenorio, 2015). Para crear una identidad es necesario interactuar con personas contemporáneas, compararse con otros. El usuario se asemeja a un modelo aunque no sea consciente de la influencia de los otros en su identidad.

Es importante sentirte reconocido, tomado en cuenta. El joven observa otras fotos y se pregunta por qué otro tiene likes y él no los tiene, entonces indaga las estrategias que al otro le produce likes. El psicólogo afirma que "si un sujeto siente que no tiene importancia se seca, no es baladí buscar que el otro te comente" (Tenorio, 2015). Los sujetos satisfacen su necesidad de interacción y aprecio a la red, si alguien comenta halagando la foto de un amigo, este amigo también comentará favorablemente al otro. Para Blumer el estatus o prestigio que alguien puede tener en un círculo se presenta en el tipo de relaciones humanas recíprocas (1982, p. 22). Es lo que sucede en Facebook con la etiquetación de las fotos y los likes. Se crea una reciprocidad para sentirse toma-

de color, y la nitidez. Poseen además las habituales opciones para rotar, recordar y redimensionar las imágenes. 


\section{5}

do en cuenta, por ello se recurre a etiquetar a amigos en las fotos que se suben a la web aunque estos amigos no se encuentren en la foto.

Las poses o estilo de fotografía que imitan los adolescentes son de personas mayores y a la vez cercanas. Puede hacerlo para pertenecer a un grupo, para estrechar lazos de amistad, o porque están probando diferentes apariencias, “juegan con el look para ver que les gusta más y encajar con todos” (Informante A., 2015).

Facebook es un espacio de prueba para saber que "Yo" gusta más a las personas, es un espacio de aciertos y errores sin permanencia. Si una foto no recibe los likes que se esperaba se la puede eliminar. El estilo no es fijo, como tampoco los gustos sobre otras fotos o sobre sí mismo. Blumer (1982) explica que los objetos se redefinen a medida que el sujeto les da significado, cuando un sujeto se define a sí mismo a partir de su foto se vuelve un objeto autoconstruido. Sus actos con los demás o consigo mismo se constituyen con base en el tipo de objeto que él ha constituido para sí. Por ello, el usuario cuando incorpora, tras una "negociación”, los significados de otros usuarios autoconstruyen una línea de expresión para sus retratos, pero a la vez el significado del retrato se encarna en sus relaciones con las personas, manifestándose su identidad fotográfica a las inter relaciones.

Las informantes clave de sexo femenino creen que los adolescentes aceptan a quienes se visten en la vida cotidiana como en las fotos donde se posa excesivamente, dicen que los chicos hablan de ellas a veces mal a veces bien, pero las jóvenes que no se visten de esa manera o no tienen ese tipo de fotos pasan desapercibidas, nadie habla ni bien ni mal de ellas. Todas quieren ser reconocidas, cada una de manera diferente y sobresalir. Sin embargo las informantes clave (2015), en particular dos de ellas afirman sentirse incómodas al tener fotos donde se vea mucho su escote o resalte mucho su cuerpo, se sienten incómodas con las fotos donde su cuerpo no se vea estético (Informante B., 2015) (Informante C., 2015). 


\section{6}

Pese a que el grupo focal no considera que sus fotos sean muy parecidas a las de los demás, se puede constatar a partir de la observación de perfiles en las fotos, que presentan el mismo lado de la cara o las mismas muecas, aunque cambie el estilo de ropa, peinado o maquillaje. Aunque estén en grupo o solos el tipo de fotos y la pose es la misma. Tampoco creen que copien o hayan copiado la pose de la foto de un amigo, porque se vea bien o tenga aceptación.

"A veces, hay personas que si no te ves como ellos en Facebook te separan de sus amigos" (Informante A., Entrevista 14 años de edad, 2015).

En realidad aunque no sea una actitud planificada copiar las fotos de sus amigos, los adolescentes se ponen en el lugar de sus amigos para contemplarse a sí mismos, desde los ojos de sus amigos, mirándose como otro lo miraría Es parte intrínseca del proceso de configuración de significados y lineamientos para comportarse de cierta manera en Facebook.

Facebook se presenta como un espacio donde se puede sondear lo que gusta a los otros, presenta las estrategias de cómo hacer para que ser reconocido. Todo ello en torno a la apariencia física, lo que hagas o dejes de hacer interesa menos a cómo te ves hoy. Por esta razón los gustos, como pasatiempos, el amor a la música, al deporte, y otros, no se presenta en la identidad retratada en la web. Como no se vive el pasado tampoco se vive el futuro, vale el presente, y en ese contexto crece y construye su identidad el sujeto comunicacional contemporáneo. Estas pautas establecidas de lo que se debe presentar en Facebook, conformado por una interacción social online y offline perduran según Blumer por "el continuo empleo de los mismos esquemas de interpretación; y estos a su vez solo se mantienen por el hecho de ser constantemente confirmados por los actos de definición de los demás” (Blumer 1982, p. 40). Los usuarios son entonces quienes mantienen arraigado a ellos y a Facebook los signos para que una foto sea o no apreciada al aceptar y reproducir los parámetros en sus fotos y en sus likes. 


\section{7}

Facebook es sólo para pasar el tiempo y subir fotos, solo se muestran características físicas de la persona o las actividades que hace, pero es diferente, cómo se toma la foto y cómo es en la vida real, las fotos son sólo porque quieren ser aceptados entre sus amigos, muestran sólo cuando se divierten y no muestran sus problemas. Sólo tus amigos más cercanos saben cómo eres (Informante C., 2015)

Todos los informantes clave concuerdan con ello, aunque dicen que para conocer a las personas sirven las publicaciones en el muro. La identidad que los jóvenes quisieran presentar es atravesada por un filtro, el de la interpretación de quién está al otro lado de la pantalla, por ello atravesar la adolescencia (desde términos médicos) no es sencillo con Facebook, pero a veces es necesario. ¿Y cómo quiere ser reconocido el grupo de estudio? Como personas felices, quieren ser comprendidos, diferentes, valiosos y a veces eso no lo logran al estar en sus casas y en su colegio. Facebook se vuelve una fuga de emociones a través de la corporalidad. La mayoría no tiene apoyo para fortalecer sus talentos deportivos, musicales y otros, están en su casa pasando el tiempo en Facebook, fotografiándose y comparándose con otros chicos de su edad. Lo que a la mayoría le gusta hacer es practicar deporte, música, leer o videojuegos, pero estas actividades raramente aparecen en sus fotos de perfil.

El individuo orienta su comportamiento en función de aquello que toma en consideración sobre el comportamiento de los otros y de sí mismo, para ello debe ponerse en el lugar del otro y conocer el movimiento próximo que va a hacer y lo que espera que él haga. La configuración de significados en Facebook es como un juego de ajedrez, hay que adelantarse a los gustos y reacciones de los amigos. Reflexionar sobre la influencia de los otros usuarios en la representación de la identidad y la construcción de significados en Facebook permitiría que los jóvenes conscientemente decidan qué características y significados aceptan y lo que dejan de lado. Reconocer una acción conjunta, en el interaccionismo simbólico, le permitiría orientarse a sí mismo para interpretar el accionar de otros y poseer una clave para su propio accionar en contexto a los demás (Blumer, 1982, p. 16). 


\section{8}

\section{Conclusiones}

Los jóvenes obvian el hecho de que detrás de la pantalla hay muchas subjetividades que interpretan las fotos y no necesariamente como al creador de esa foto le gustaría. Durante el proceso de fotografiarse y colgar la foto en la web los jóvenes no están frente a un individuo para interactuar, están frente al lente de una cámara y eso disminuye la percepción de la realidad. Más del 70\% de los encuestados consideran que son reconocidos entre sus amigos por cómo se ven en fotografías de perfil. De alguna manera se desinhiben frente a la cámara porque tienen la oportunidad de presentarse de varias formas y seleccionar la imagen que más les gusta para presentarse al mundo digital a través de una fotografía.

Una de las claves del interaccionismo simbólico consiste en que para crear significados el sujeto debe pensar y actuar como el otro, pero para los jóvenes, ese pensar difiere entre el mundo digital y el físico. Ellos consideran que las personas son falsas al presentarse en Facebook como no son cotidianamente, por ello el 51\% de los encuestados no rechazan las fotos donde se posa excesivamente, pues la imagen que ellos presentan de sí mismos no es la que tienen a diario. El significado de las fotos se transforma al presentar leves variaciones en ellas, los usuarios crean parámetros de lo que les gusta o no les gusta desde la interacción en Facebook de sus fotos y las fotos de los otros.

Blumer (1982) explica que la interacción entre los sujetos pertenecientes a una sociedad es lo que crea los significados de este grupo. Si estos significados se crean en el intercambio de likes en Facebook al ser una plataforma con amplitud de usuarios permite a un joven, al subir una foto suya, sondear la aceptación que tendrá en la vida offline ese sujeto que presenta en la web.

La gran pluralidad de perceptores y expositores en Facebook no es retenida en la lógica del usuario. Facebook es un reflejo de la modalidad instantánea del mundo contemporáneo y lo trascendental es el gran 
flujo de información y su rapidez. No hay tiempo para reflexionar. Los jóvenes usuarios de la red no terminan de comprender que esa pluralidad que se ofrece en la pantalla les permite escoger a su gusto características para retratarse, pero que eligen de lo ya establecido. Cerca del 70\% de los encuestados utilizan Facebook desde que tienen 10 a 12 años de edad, y solo el 3\% del total de encuestados utilizan otra red social donde las fotografías es la principal forma de comunicarse.

La identidad offline no se manifiesta con tanta importancia como las fotos en Facebook, no hay cumplidos y likes cotidianamente en la vida offline. Pero hay quienes no prestan atención a sus fotos y su identidad offline corre el riego de marchitarse porque ellos mismos no creen que sea importante para el público. En algún punto todos quieren sentirse alagados, aceptados y valiosos. La interacción en Facebook puede brindar esa sensación por la complicidad que ofrece al ser un espacio "seguro" para definir apariencias y permitir ser parte de un grupo.

Si el usuario siente que no se acopla a los parámetros de Facebook cree que no puede participar de esta interacción, porque solo le queda reproducir patrones y que no vale la pena publicar una nueva identidad. En realidad ese usuario puede insertar sus significados en el grupo de significados de sus amigos y generar cambios en el significado social, lo cual no se puede hacer con una estética de lo grotesco, lo rechazado. La estética a través de las fotografías puede ser generadora de contenido potencial para influenciar en las representaciones de los usuarios. El 60\% de los encuestados otorgan reconocimiento mediante likes a las fotografías donde la apariencia física de los usuarios es estéticamente atractiva.

¿Qué quiero ser? ¿Qué me gusta hacer? ¿Qué me diferencia de los demás? Al parecer los miembros del grupo no lo tienen claro, aunque si saben que quieren que los perciban como personas alegres, que los conozcan como son y no por lo que interpretan en sus fotos. Para que las personas los conozcan como son deben mostrarlo en las fotos, pensando en cómo me percibirá quien está del otro lado de la pantalla. Nadie se 


\section{0}

escapa de ser interpretado aunque suba o no suba fotos en Facebook. Si bien muchos de los espectadores en Facebook son amigos o conocidos, muchos otros no tienen cercanía al usuario y lo interpretan a partir de lo que ven en las fotos.

Inclusive la familia y los amigos, a pesar de tener aparentemente clara la identidad del usuario se guían por el instante. Lo que ven en el perfil hoy resulta más cercano y verdadero que como vio a la persona la semana pasada. Además, se puede considerar que las fotografías manifiestan lo que es la persona sin tapujos y que como se la conoce presencialmente es una pose adoptada que se manifiesta acorde a la situación, al contexto.

Viviendo en una sociedad selectiva, donde las personas deben lucirse para ser tomadas en cuenta, las personas deben diferenciarse de los demás pero esa diferenciación en Facebook conlleva a la intolerancia abriendo espacio a la violencia. Hay diferentes tipos de violencia como excluir y juzgar, lo que se presenta en este grupo de jóvenes, en baja medida, pero existe.

Los jóvenes quieren diferenciarse de los demás y al mismo tiempo encajar con los gustos de sus pares. Mientras los usuarios no acepten que la representación de su identidad mediante fotografías es un conglomerado de estéticas pre dichas y que pueden permitirse crear otras estéticas sin necesidad de dejar de sentirse y proyectarse como quieren ser, no lograrán representar quienes ellos son y quienes quieren ser, porque los adolescentes aún están construyendo su representación para el mundo.

Para futuras investigaciones se recomienda realizar más talleres con los adolescentes en grupos pequeños y conducir el proceso exploratorio durante un tiempo más prolongado. Se recomienda que preferiblemente los grupos de jóvenes no se mezclen entre paralelos y edades diferentes para que se sientan más cómodos al expresar sus opiniones. Además aprovechando los talleres conviene enfocarse en analizar la posibilidad de ser generadores de contenidos. 


\section{Bibliografía}

Almansa, A., Castillo, A., y Fonseca, O. (2013). Redes sociales y jóvenes: Uso de Facebook en la juventud colombiana y española. Comunicar: Revista Científica Iberoamericana de Comunicación y Educación, 40, 127-134. Obtenido de https://goo.gl/ZSVMbE

Blumer, H. (1982). El interaccionismo simbólico. Perspectiva y método. Barcelona: Hora S.A.

Bonet, G. (2010). Cibersocialización y adolescencia un nuevo binomio para la reflexión en educación social. RES: Revista de Educación Social, 11. Obtenido de https://goo.gl/9Qh8pJ

Cuesta, U. (2000). Psicología social de la comunicación. Madrid, España: Catedra Editores.

Dillon, A. (2013). Miradas de adolescentes argentinos sobre la intimidad en Facebook. Anàlisi: Quaderns de comunicació i cultura, 49, 15-28. Obtenido de https://goo.gl/U3ub5a

Firth, A. (2010). Discurso \& Sociedad. Etnometodología, 42010, 597-614. Traducido por Teresa E. Cadavid G. Obtenido de https://goo.gl/UVJwHt

Flores, R. P. (2012). "Juntos y solos" el último libro de Sherry Turkle, Alone Together: Why We Expect More from Technology and Less from Each Other. Revista Iberoamericana de Comunicación, 23, 83-88. Obtenido de https://goo.gl/QWFGTZ

Flores, J. M. (2009). Nuevos modelos de comunicación, perfiles y tendencias en las redes sociales. Comunicar, Revista Científica de Educomunicación, XVII(33), 73-81. España. Obtenido de https://goo.gl/RJUc9m

Fuentes, M.M. (s.f.) Reflexiones sobre la identificación y la identidad. Obtenido de https://goo.gl/jsTuFC

Hall, S. (1997). Representation: Cultural Representations and Signifying Practices. London: Sage Publications, Cap. 1, pp. 13-74. Traducido por Elías Sevilla Casas.

Lozano, J. (2007). Teoría e investigación de la comunicación de masas. México: Pearson Educación.

Moreno. F. (2013). Remember my name. La construcción de la popularidad online por parte de adolescentes usuarios de Facebook. Cuadernos de H Ideas, 7. Obtenido de https://goo.gl/Q6mTSk

Manovich. L. (1998). Estética de los mundos virtuales. El Paseante. La revolución digital y sus dilemas, 20, 93-96. Madrid: Ediciones Ciruela. 


\section{2}

Pérez Bonet, G. (2010) Cibersocialización y adolescencia: un nuevo binomio para la reflexión en educación social. Revista de Educación Social, 11. Obtenido de https://goo.gl/vYGxdw

Turkle, S. (1997). La vida en la pantalla. Barcelona: Editorial Paidós.

Von Doellinger, O. (2011). Cuerpo e identidad estereotipos de género. (Tesis doctoral). Universidad Ramon Llull. Obtenido de https://goo.gl/VesPK5

\section{Entrevistas}

Informante, A. (16 de junio de 2015). Entrevista 14 años de edad. (P. Castelo, Entrevistador).

Informante, B. (16 de junio de 2015). Entrevista 13 años de edad. (P. Castelo, Entrevistador).

Informante, C. (16 de junio de 2015). Entrevista 15 años de edad. (P. Castelo, Entrevistador).

Informante, D. (16 de junio de 2015). Entrevista 14 años de edad. (P. Castelo, Entrevistador).

Suriaga, E. V. (18 de julio de 2015). Entrevista comunicador. (P. Castelo, Entrevistador).

Tenorio, R. (13 de julio de 2015). Entrevista sicólogo. (P. Castelo, Entrevistador). Vásquez, J. D. (17 de julio de 2015). Entrevista sociólogo. (P. Castelo, Entrevistador). 


\title{
Capítulo 4 \\ Representación de la mujer latinoamericana en el cine comercial
}

\author{
Nina Aguiar Mariño \\ Jossye Crespo Venegas
}

\section{Resumen}

El cine comercial genera una gran influencia en el ámbito comunicacional de la sociedad, donde el discurso que éste presenta es un fuerte referente, sobre todo en la sociedad latinoamericana. Identificar los roles y estereotipos de la mujer latina en el cine comercial no solo responde a la necesidad de señalar cual es la representación femenina en Hollywood, sino a tomar conciencia que dichas representaciones influyen en la mirada de la mujer hispana dentro de la sociedad anglosajona e incluso dentro de su propia sociedad. El objetivo principal radica en el análisis e identificación de dichos roles y estereotipos, basado en su transformación en la sociedad latinoamericana a partir de la última década. Además, ver que parámetros promueven el cambio de dichos roles en la mujer dentro de su sociedad y la construcción de la imagen estereotipada en el cine comercial. Derivando indiscutiblemente en la utilización de la imagen de la mujer latina como objeto sexual y sensual.

\section{Introducción}

La incursión de la mujer latinoamericana en el cine comercial, pone en el escenario la asignación de nuevos roles y estereotipos establecidos desde la cultura anglosajona hacia la mujer latina, que a la larga repercuten en los imaginarios de la cultura y feminidad latina y su visibilización y alienación en el exterior.

Las dimensiones culturales de desarraigo y de la movilidad espacial unidas a la migración y a una creciente fragmentación de los espacios de vida constituyen probablemente el factor principal de la incursión de la mujer latina tanto en la cultura anglosajona, como en el cine 
comercial. Ahí surge el punto de partida, puesto que la mujer migrante se constituye como la nueva fuerza laboral; una figura femenina distinta a la mujer burguesa estadounidense, donde los roles que empieza a desarrollar van ligados al esfuerzo y sacrificio, y tornándose en centro de atención por su belleza y carácter marcados desde su genética cultural.

Si la incursión de la mujer en el cine tuvo sus épocas de difícil aceptación, o fue simplemente considerada en papeles secundarios como "aquellas damiselas que debían ser rescatadas de sus castillos"; la incursión de la mujer latina fue aún más difícil, no sólo porque ella no entró como la "señorita indefensa" sino como la criada o sirvienta.

El pueblo sudamericano cubierto por la sombra de la colonización, es visto bajo la mirada discriminatoria del pueblo anglosajón, y por ende su industria cinematográfica manejará la concepción del pueblo subyugado y nacido para servir. Las mujeres mestizas fueron tomadas en cuenta solo para papeles de servidumbre y sobre todo en las películas western, ${ }^{13}$ como mujeres que eran objeto de abuso sexual y racial. La mujer ya no solo era sesgada bajo su condición de mujer en sí, sino ahora también bajo su origen sociocultural.

Con el paso del tiempo y bajo distintas coyunturas sociales, la figura femenina latina fue ganando campo en otros roles del cine, obteniendo identidad, hasta convertirse actualmente en un importante referente. La migración hacia Estados Unidos hizo necesaria la incursión de papeles mestizos, para que exista una equidad racial y se diera la identificación y proyección del público con los personajes presentados. Sin embargo el logro es solo haberse posicionado como un referente cultural en el cine comercial, ya que el rol de la mujer latina no difiere mucho de las primeras incursiones en el cine. Ya no es la indígena deni-

13 Western es un adjetivo derivado de la palabra west ("oeste” en inglés) y que se utiliza comúnmente para referirse al género cinematográfico de las películas estadounidenses que son ambientadas en el "Viejo Oeste" y que en Iberoamérica se las conoce como películas de vaqueros. 


\section{5}

grada y menospreciada, pero su origen racial y exoticidad sigue siendo el referente por la cual se la mantiene dentro de un estereotipo único en el cine anglosajón.

La mirada sexuada de la mujer latina no cambia, solo se le da un posicionamiento distinto, ya no es la indígena abusada, ahora es la mujer cuyo cuerpo es deseado por el hombre debido a que expresa sensualidad. Con el nacimiento del feminismo en la década de los 70 las autoras de esta línea postularán mediante el psicoanálisis que "el cine hollywoodense identifica el placer con la mirada masculina e invita así a las espectadoras a identificarse, a mirarse a través de él, a alinearse con esa objetualización de la mujer" (Mattelart y Neveu, 2003, p. 88).

La apreciación del género está dada desde las construcciones socioculturales manifestadas en las diferencias de consumo y de la valoración que se da entre hombres y mujeres en la televisión, el cine y los bienes culturales; donde los mecanismos de dominación por el enaltecimiento de la cultura de los dominados, estarán dados desde su punto de vista.

El cine comercial, pondrá a la mujer bajo los roles que expresen sexualidad, belleza, exaltamiento del cuerpo y placer; los medios harán esa grande distinción entre los géneros, buscando que la mujer se vea reflejada en el cine como un objeto material y dándole siempre el sentido de sensualidad, sea cual sea el rol que desempeñe la mujer, implicará el placer por sobre todas las cosas.

Las producciones cinematográficas actuales han hecho que el rol de la mujer latina vaya ligado a la explotación de la sexualidad y sensualidad, imaginario que se le ha dado a la figura latina tomando en cuenta únicamente su belleza física. Representación de gran influencia dentro de los estereotipos, donde las actrices representarán el ideal de belleza femenina y será el modelo que muchas mujeres anhelan llegar a ser. La sociedad anglosajona tiene el referente de que la mujer latina es hermosa por naturaleza, valoración derivada principalmente desde la mirada masculina. 


\section{6}

Es común ver que el personaje latino lleva la ropa más entallada o expone su belleza acorde al personaje asignado; ya sea en una película de acción como en una comedia el vestuario denotará "los atributos" de la actriz. Es así que los roles asignados a la estrella latina, son de mujer fatal o la mujer fuerte y valiente. Es suficiente considerar los papeles desempeñados por Michelle Rodríguez y Eva Mendes en sus películas más destacadas.

Se podría decir que las actrices latinas han logrado posicionarse en Hollywood como los más altos referentes y representantes latinos, sin embargo hay que notar que esta industria no reconoce a la actriz por su desempeño sino por lo que ella representa. Es claro que a la actriz se le asigna roles donde se pueda poner en evidencia su buen cuerpo y sensualidad, encasillándola en un único papel y buscándola únicamente para ese tipo de actuaciones. Si bien la posición que se han ganado dentro de este ambiente competitivo es digno de aplaudirse hay que resaltar que la actriz no adquiere un crecimiento profesional al no permitírsela explorar otro tipo de papeles, ya que para el cine comercial no conviene que la mujer mestiza se posicione en otro tipo de roles.

Esta situación corresponde a lo que Judith Butler considera acerca del género. Se construye socialmente con base en las configuraciones sociohistóricas, (Butler 1999) es así que la feminidad no será más que esa imposición desde las hegemonías del poder, donde la mujer como objeto de placer está pensado en el favorecimiento de la masculinidad; por tanto sus estudios buscan sacar del imaginario de la sociedad, el género impuesto de mujer como rol creado para complementar y satisfacer al hombre.

Para Judith Butler, en la sociedad actual las personas viven sometidas o rebajadas en función de la aplicación de categorías como sexo, género y sexualidad. Los roles asignados a las actrices latinas se barajan entre la sensualidad, la valentía, el deseo pasional y la belleza exótica, para crear el imaginario de que la mujer latina es "caliente" y que vale más por su belleza y carácter que por su inteligencia. 


\section{7}

Los medios participan de forma relevante en la información, el entretenimiento y en consecuencia en el modo de percibir y concebir el mundo. Además, la hegemonía juega un papel clave al momento de analizar la mirada anglosajona hacia la mujer latinoamericana. El poder que ejerce Estados Unidos sobre el continente sudamericano hará que este consumo cultural marque opciones identitarias e ideológicas bajo el juego mediático.

Por su parte Raymond Williams (2001) se preguntará ¿Cómo la clase obrera crea significados distintos de la lectura preferida dominante? Si bien el estereotipo que se presenta dentro del cine es uno, el significado que construyen los receptores —en este caso las mujeres latinoamericanas - será otro, no muy distinto pero si percibido desde su contexto cultural. Stuart Hall (Terrero, 2006) establecerá que existen dinámicas donde hay un disfrute mediático por parte del público, es este quien busca esos modelos estereotipados, se apropia de los mismos y los reproducirá en lo posterior.

Hall también cuestionará las tendencias marxistas, especialmente porque no verían que la especificidad de los medios consiste en que se trata de una práctica social, que produce productos simbólicos. El cine ya no solo se convierte en un medio de manipulación sino en construcción de simbolismos que ponen en escena nuevas formas de edificación social, nuevas formas de ver la imagen de la mujer latinoamericana desde la mirada de Hollywood. Los estereotipos que plantea el cine comercial, serán vistos desde la mujer latina como símbolo de orgullo; el hecho de que una actriz latina esté presente en ese ámbito no solo es visto como un ejemplo de admiración y de presunción, sino también como una referencia de comportamiento y ejemplo a seguir para poder encajar en ese mundo anglosajón. Es alcanzar el sueño americano, un anhelo dorado que toda mujer busca.

Mediante la codificación/decodificación que establece Hall, la audiencia crea una cultura alternativa, la sociedad femenina verá en el cine comercial, dos aspectos opuestos en la representación de la mujer latina: 


\section{8}

Desde las corrientes feministas, se juzgará que la mujer latina sea representada como símbolo de sensualidad, de lujuria y que se le asigne el rol sexy de la película explotando sus atributos físicos.

Desde el punto de vista del pensamiento colonizado que sufre Latinoamérica se dirá que la incursión de actrices latinas, es un paso importante en el reconocimiento de Latinoamérica como participante importante en la sociedad anglosajona. Ellas son un ejemplo de lucha y superación por obtener un lugar de reconocimiento.

Bajo estos parámetros, tanto el estudio de género como los estudios culturales, constituirán el camino para el desarrollo del tema. Se dará una mirada hacia el análisis del rol de la actriz latina en del cine comercial y sus cambios evolutivos, así como la visualización de la mujer latinoamericana desde la cultura anglosajona y su influencia en la sociedad hispana. Se establecerá básicamente que los estereotipos que maneja y presenta el cine comercial con respecto a la mujer latinoamericana en la última década, influye en el cambio de roles a lo largo de este periodo de tiempo, afectando el desenvolvimiento de ésta en la sociedad latinoamericana.

La mirada de la mujer como objeto de deseo, como problemática, vendrá desde la observancia de la sociedad como algo a lo que se debe aspirar. Las mujeres buscan ese ideal de feminidad puesto que es lo que atrae miradas y es elogiado, los hombres buscarán mujeres constituidas con ese "atractivo físico", prototipo de mujer perfecta. Los medios pondrán en vitrina ese tipo de concepciones como eje de sus aspiraciones, descontextualizando la realidad y por ende presentando un panorama alienado.

Se dirá que "la cultura popular es fruto de las mediaciones, intercambios, resistencias y asimilaciones en la cultura dominante" (Sorice, 2005, p. 136). No se trata simplemente de manipular, sino de generar un liderazgo cultural que logra el consenso de los grupos y de las clases subordinadas. La hegemonía controla al pueblo incorporando lo popular 


\section{9}

y el mayor número posible de subculturas. La incursión del rol femenino latinoamericano corresponde al objetivo de la sociedad anglosajona de abarcar todas las culturas posibles, dar una amplitud carente de racismo y por tanto de inclusión en sus construcciones cinematográficas, como reflejo de su nueva mirada de la cultura que les rodea; pese a ello la mujer latinoamericana queda enfrascada muchas veces en roles y estereotipos que no concuerdan con la verdadera realidad latina, sino con la mirada anglosajona de lo que ella debe representar.

Hall desarrolla un marco teórico que pone en evidencia que el funcionamiento de un medio no puede simplemente limitarse a la transmisión mecánica (emisión/recepción), sino que le da forma al material discursivo en el que intervienen datos técnicos, condiciones de producción y modelos cognitivos. Por un lado estarán las gramáticas mediáticas que prevalecen en la producción del mensaje y por el otro se encontrarán las referencias culturales de los receptores. Las primeras buscarán promover el mensaje de la mujer con estereotipos marcados y dados específicamente para que las clases "subdesarrolladas" se sometan al dominio y visión del promotor; la segunda por su parte generará un contrapeso que va desde la construcción histórico-cultural no enajenada que prevalece y se impone sobre lo colonizado, enalteciendo esas características latinas que nos diferencian de la cultura anglosajona.

\section{Metodología}

Para esta investigación se trabajó en primera instancia con un enfoque descriptivo puesto que detalla los roles y estereotipos presentes y recurrentes en el cine comercial y que se han identificado como influyentes en la sociedad anglosajona y latinoamericana. Se ha tomado como puntos referenciales las actrices de origen latino o cuyos padres sean de origen latino y que tengan papeles destacados en el cine hollywoodense, para analizar los personajes que ellas interpretan en las diferentes películas y trasladar la observación a los resultados mediante estudios de caso. 


\section{0}

Se han tomado específicamente como ejemplos a Salma Hayek, Jessica Alba, Michelle Rodríguez y Eva Mendes ya que cumplen los requerimientos planteados para esta investigación, y sobre todo porque son figuras exaltadas en Hollywood por su atractivo físico, personalidad y excelentes actuaciones.

Posteriormente se utilizó un enfoque crítico-reflexivo para analizar los estereotipos y su influencia en el comportamiento de la mujer latinoamericana. El trabajo se guía esencialmente en la teorización, con conceptos y teorías que soportan los planteamientos realizados sobre la temática, de manera que se genere una nueva comprensión sobre la problemática. Se complementó con el método comparativo, de estudios de caso, como contextos de análisis, cuya utilización explica la relación entre los referentes dados en el cine comercial y los imaginarios instituidos en la sociedad latinoamericana.

Se realizó además, un análisis de discurso, para descubrir las intenciones y significaciones escondidas tras los roles asignados a las actrices latinas, y para la deconstrucción de los estereotipos. Este tipo de análisis tiene como procedimiento transitar de lo macro a lo micro, trabajar con la semiótica y los significados que están detrás de cada película y de la mirada anglosajona hacia las actrices latinas. Para lograrlo se efectuó una investigación explicativa, con el propósito de buscar la causa de los hechos, mediante el establecimiento de relaciones causa- efecto, respondiendo a las preguntas del por qué y del como del evento en estudio. Cabe recalcar que una explicación no amerita necesariamente una verificación; la explicación se limita a establecer relaciones, mediante la observación, descripción y comparación.

El diseño de la investigación es de carácter documental, puesto que las fuentes no son vivas y se basa en la obtención y análisis de datos provenientes de materiales impresos y otros tipos de documentos audiovisuales, específicamente las películas seleccionadas. Paralelamente se realizó un diseño contemporáneo puesto que se trabaja en una temporalidad de actualidad, ya que se enfoca y analiza los casos de actrices 
latinas que han tenido éxito y trascendencia en el cine hollywoodense en la última década. La investigación se complementó con una revisión bibliográfica con base en la recogida de información de las muestras establecidas en los estudios de caso.

\section{Criterios de selección de las actrices para estudio de caso}

Para la selección de cuatro actrices se tomó en cuenta tres puntos claves:

- Origen latino (nacidas en un país latinoamericano cuyos padres sean latinoamericanos).

- Películas donde han trabajado (4 películas referenciales).

- Éxito dentro de la comunidad anglosajona y latinoamericana.

Salma Hayek Jiménez (48 años). Nacida en Coatzacoalcos, México; llega a Hollywood en 1991, recibió una nominación a los Oscar, los BAFTA y a los Globos de Oro, como mejor actriz por el papel de Frida Kahlo, en la producción cinematográfica "Frida". Entre sus papeles más recordados están: Carolina en “Desperado” y "Erase una vez México”; Rita Escobar en "Las aventuras de Jim West" y Sara Sandoval en "Bandidas".

Jessica Marie Alba (34 años). Nacida en Pomona, California, su madre es de ascendencia danesa y franco canadiense y su padre es mexicano. Ha sido nominada en los Nickelodeon Kids Choise Awards como actriz favorita por la película "Los 4 Fantásticos". Apareció en la sección "Hot 100" de Maxim y fue votada número uno en AskMen.com entre "Las 99 mujeres más deseadas" del 2006, como también "La mujer más sexy del mundo" por FHM en 2007. Entre sus papeles más recordados están: Kirsten Liosis en la película "Jamás besada"; Nancy Callahan en "Sin City: Ciudad del pecado"; Morley Clarkson en "Valentine’s Day" y su papel más destacado como Sue Storm la mujer invisible en las dos películas de "Los 4 Fantásticos".

Mayte Michelle Rodríguez (36 años). Nació en San Antonio, Texas; su padre Rafael Rodríguez es puertorriqueño y su madre Car- 
102

men Milady es de República Dominicana. El "Entertainment Weekly" la calificó como "la actriz latina más exitosa de Hollywood". Sin duda su papel más reconocido ha sido Letty en la franquicia de "Fast and Furious", pero igualmente ha tenido papeles destacados en otras franquicias como "Resident Evil" interpretando a Rain Ocampo. Interpretó a Trudy Chacón en "Avatar” y a Chris Sánchez en "S.W.A.T."

Eva Mendes (41 años). Nació en Miami Florida, de padres cubanos. Obtuvo el puesto número 7 en la revista Maxim en las "Hot 100" del 2007 y 2008, y el puesto número 44 en la revista FHM en "Las 100 mujeres más sexis del mundo” en el 2006. Participó como Mónica Fuentes en la película "2 Fast 2 Furious", fue Alex Díaz Whitlock en "Out of Time". Su papel más recordado ha sido Sara Melas en "Hitch" e interpretó a Ajedrez en "Erase una vez México". Hay que recalcar que fue actriz invitada y obtuvo excelentes críticas en la película francesa "Holy Motors" representando a Kay M.

Con estos referentes y como un patrón básico se tomó solamente una película para analizarse por cada actriz. Se retuvo el género de acción, debido a que en ese tipo de películas, el rol que cada actriz interpreta responde a los ejes centrales de la investigación. Por un lado, la mujer como figura de acción, fuerte y valiente, y por otro lado, sus personajes denotan sensualidad y sobre todo se resaltan sus atributos físicos.

Se seleccionaron las siguientes películas:

$\begin{array}{ll}\text { Salma Hayek: } & \text { Desperado } \\ \text { Jessica Alba: } & \text { Los } 4 \text { Fantásticos } \\ \text { Michelle Rodríguez: } & \text { The Fast and the Furious } \\ \text { Eva Mendes: } & \text { 2 Fast 2 Furious }\end{array}$

El resto de películas se tomaron en cuenta en un segundo plano, como ejes de referencia.

Las actrices escogidas tienen origen latinoamericano o ascendencia latina directa. Sus rasgos corporales corresponden con el imaginario 
de "mujer latina" que destacan por su belleza física. Son actrices reconocidas en el mundo entero por los papeles que han desempeñado en películas famosas como "Fast and Furious", "Residen Evil", y "Los 4 Fantásticos". Su imagen dentro de la sociedad anglosajona las sitúa como actrices destacadas y de gran trascendencia. Para la investigación son referentes perfectos para lograr el propósito planteado.

Con base en la estructura aristotélica de los tres actos: planteamiento, confrontación y resolución; se pone en evidencia el desarrollo del personaje en la película. En el planteamiento se presenta una introducción de la película, así como la entrada y presentación del personaje. En la confrontación se desarrolla el conflicto de la trama y se analiza el conflicto personal y psicológico del personaje, así como su postura frente a los obstáculos que se le presentan. En la resolución se concluye la historia y se disipan todos los conflictos del personaje.

Bajo esta estructura cada actriz cumple líneas similares dentro de las diferentes películas de Hollywood.

Salma Hayek en la película "Desperado", y su personaje Carolina es introducida como una bibliotecaria, que destaca en el pueblo por su belleza y es objeto de deseo y amor del Mariachi (Antonio Banderas). Al final se convierte en una bandolera sexy compañera de batalla y venganza del protagonista.

Jessica Alba en las dos películas de "Los 4 Fantásticos” interpreta a la científica Sue Storm, la mujer invisible. Ella forma parte de la misión o expedición espacial encabezada por Reed Richards y el doctor Victor Von Doom. Una radiación cósmica afecta a los tripulantes de la nave otorgándoles diferentes poderes. El personaje se posiciona como la mujer heroína del grupo y en objeto de disputa amorosa entre Reed y Victor. Como en la mayoría de películas de súper héroes se caracteriza a Jessica, la protagonista femenina, con un traje entallado y que resalta principalmente la voluptuosidad de su cuerpo. 


\section{4}

En la segunda película vemos a una Sue Storm en su lado más sensible, cuya prioridad ya no es ser una heroína sino que se nos presenta como una chica que busca una relación más seria y estable con Reed. Por otra parte vemos a la heroína que busca ir más allá de las batallas y se pone en contacto con el villano de turno, Silver Surfer. Al ser una película de acción y de súper héroes basada en comics, el personaje femenino está dirigido y construido desde la mirada masculina, resaltando sus atributos físicos y convirtiéndola en una súper héroe sexy.

Michelle Rodríguez dentro de toda la franquicia de "Rápidos y Furiosos" presenta un personaje que deja la sensualidad en segundo plano. Interpreta a Letty, novia de Torreto (Vin Diesel), como pareja acorde a él, representa a una chica ruda y fuerte que no deja de ser atractiva. En el desarrollo del personaje pasa a tomar un protagonismo relevante a partir de la 4ta película y se fortalece en la 6ta película. Letty deja de ser solamente la novia y apoyo de Torreto para convertirse en un personaje clave. Esta franquicia pone en escenario una mujer atractiva a la mirada de los hombres no solo por su aspecto físico sino también por el contexto en el que se desenvuelve, Letty es una mujer sexy, valiente y con un amplio conocimiento automotriz similar a su compañero masculino, por lo que se constituye en una combinación ganadora ante la vista de la mayoría de los hombres.

En esta misma franquicia pero solo en la segunda entrega Eva Mendes tiene un rol similar al de Letty pero combinado con la sensualidad de la actriz. Es la mujer sexy y hasta cierto punto trofeo de la película. A diferencia de Michelle Rodríguez el personaje de Eva Mendes, la agente Mónica Fuentes, se presenta desde su entrada como una mujer fatal. La trama resalta que la importancia del personaje radica en su atractivo físico y gracias a ello, puede involucrarse con el narcotraficante Carter Verone, para llevar a cabo su misión como agente encubierta. Pese a la profesión que se le asigna a la actriz, la rudeza no es uno de los elementos importantes de su personaje; al contrario, sobre la profesión asignada le hacen destacar por su belleza latina. 


\section{5}

En estas películas el desarrollo de los personajes tiene un mismo sentido, si bien el rol designado varía, la característica central siempre es presentar una mujer fuerte y valiente y de gran atractivo físico. Para identificar las características centrales de las películas, que no son notorias a simple vista en el cine comercial, es fundamental identificar como se desenvuelve cada personaje dentro de la trama.

\section{Resultados}

La popularidad del cine, hace que sea imposible que las mujeres se sitúen fuera de su alcance, aun si los espectadores tienen el poder de determinar lo que ven. Se produce una confusión identitaria donde se generan contradicciones entre el ser dentro de la sociedad y las exigencias sociales impuestas por los medios. "La hegemonía es fundamentalmente una construcción del poder a través de la conformidad de los dominados con los valores del orden social, con la producción de una voluntad general consensual" (Mattelart y Neveu, 2003, p. 61). La industria cultural anglosajona, al posicionarse frente a las demás, consigue que sus símbolos culturales se conviertan en una parte integrante de la cultura, con lo cual millones de personas, incluyendo los latinos construyen sus identidades culturales, convirtiéndose en una mixtura entre lo propio y lo ajeno.

Lacan (Terrero, 2006) establece al imaginario como el reino de la subjetividad parcial, que comienza a desarrollarse en la fase pre-edípica, cuando empezamos a constituirnos por medio de identificaciones imaginarias con "otros/otras" significativos, no solo con la madre y el padre, sino posteriormente también con otros modelos, como las estrellas de cine. La imagen de la mujer como tal se dará desde los ejemplos que las niñas observen; en este caso, las niñas latinoamericanas construirán su feminidad desde los ejemplos que observen; los más predominantes son los expuestos en el cine comercial.

Lacan designa esta fase del desarrollo subjetivo como la "fase del espejo" y la considera como una identificación equivocada del niño o la 
niña con su imagen reflejada y, por extensión, con sus ideales del yo. La imagen que la niña absorba sobre la feminidad latina vendrá por ende, desde el reflejo expuesto en el cine, manejándose un yo latino construido desde la visión anglosajona.

Desde la visón del cine proyectada sobre el receptor, la experiencia del yo está fragmentada, "marcada por la incompletud, compuesta por múltiples yoes, múltiples identidades vinculadas a los distintos mundos sociales en los que nos situamos" (Mattelart y Neveu, 2003, p. 87). La mujer convivirá con dos visiones distintas, la realidad de la cultura que la rodea y la identidad que impone la cultura anglosajona. Se construye entre la ambivalencia de la realidad vivida y la realidad convencionalmente aceptable según los modelos a seguir.

El yo de ahora en adelante forma parte de un proceso de construcción de las identidades sociales en el que el individuo se define por su situación en relación con distintas coordenadas y no puede reducirse a una u otra coordenada (ya sea la clase, la nación, la raza, la etnia o el género) (Mattelart y Neveu, 2003, p. 92).

Las mujeres latinoamericanas construirán su identidad a través de lo que se le impone. La alienación con respecto a los modelos anglosajones hacen que la identidad de la región se juegue entre una ambivalencia de mezclas ideológicas.

David Morley (Terrero, 2006) considera el proceso de dominación social y el papel central que cumplen los medios en la construcción, comprensión y reproducción de un orden social y su hegemonía cultural. Según Morley, los receptores no poseen un verdadero interés por la autonomía, ya que se desliza hacia una apología ingenua donde la capacidad de los espectadores para recodificar o "piratear" el flujo de los medios invalida cualquier interrogante sobre los contenidos, son receptores pasivos que no se cuestionan el mensaje que están recibiendo, sino que lo toman como un mero entretenimiento. 
Los receptores activos "ponen en entredicho los usos que éste hace de los medios, los placeres que encuentran en éstos, la forma en que negocian sus lecturas" (Mattelart y Neveu, 2003, p. 102). Los espectadores manejarán el contenido a su favor, verán a una Salma Hayek como una excelente actriz que fue nominada al Oscar, y dejarán de lado la priorización de su belleza como "Sex symbol” en sus películas más destacadas; incluyendo la que le valió la nominación como la mejor actriz, interpretando a la artista Frida Kahlo, que llevaba connotaciones sexuales que explotaban la belleza de la actriz.

En los comienzos de los años ochenta se inicia el estudio sobre la recepción de los medios, cuya lectura será lo suficientemente potente como para imponerse a todos los receptores, y donde los consumos culturales marcan opciones identitarias e ideológicas bajo el juego mediático. Los mismos investigadores se centrarán en la diversidad de productos culturales consumidos por las clases populares. Los estudios culturales "se fijan en la aparente trivialidad de la publicidad de las emisiones de entretenimiento" (Mattelart y Neveu, 2003, p. 60), al analizar las funciones que asumen en relación con la dominación social, como las hegemonías de poder que inciden en el comportamiento de los países receptores de la cultura anglosajona.

"La noción de descodificación invita a tomarse en serio el hecho de que los receptores tienen sus estatus sociales, sus culturas, y que ver o escuchar un mismo programa no implica darle un sentido o evocar un recuerdo similar" (Mattelart y Neveu, 2003, p. 57). Si bien la mirada anglosajona verá a la mujer como un objeto de placer, desde la mirada de la joven latina, quedará en un segundo plano, la actriz Michelle Rodríguez por ejemplo, será vista como símbolo de valentía y rudeza femenina manteniendo implícita la explotación de su cuerpo. Su rol principal en las películas interpretadas es de la mujer ruda que puede afrontar la vida como lo haría un hombre; esta es la visión que tienen las jóvenes latinas, puesto que la valentía sobresale sobre la belleza de la actriz y no interfiere en el desempeño del personaje. 
La incursión de la sociedad latina en la cultura anglosajona ha provocado diferentes mixturas que desembocan en varios aspectos diferentes. Primero tenemos un Estados Unidos latinizado, la exoticidad de la belleza y el éxito de las actrices de origen latino dentro de Hollywood ha provocado que desde la mirada anglosajona la mujer latina se asocia al ideal de belleza, ideal que cobra vida en el cuerpo de la mujer latina debido a su figura estilizada y exuberante, y una personalidad chispeante y avasalladora. Sin embargo no es la mujer caucásica la que busca parecerse a la mujer latina ya que dentro de la sociedad anglosajona cada cultura tiene su lugar. Es la propia mujer latina quien asume esta mirada como el ideal a conseguir.

Las mixturas o el mestizaje entre las culturas, ha provocado también que lo latino se anglosajone. Los migrantes han logrado crear una nueva cultura, sin abandonar sus raíces autóctonas, han adoptado costumbres del país donde viven. Esta mezcla cultural posicionada entre la cultura anglosajona y la cultura latina carecerá de una identidad propia, y es ahí donde la imposición comercial se marcará con mayor fuerza. En la comunidad latina que vive en EEUU se busca que sus mujeres resalten sobre el resto, verse como las actrices de cine es fundamental, ellas son la moda que hay que seguir, porque representan lo propio. Es un ejemplo de la lucha, posicionamiento e importancia en un país donde han sido subyugados.

Desde Latinoamérica, la región visualiza los cambios de su cultura, que en cierta medida permanecen enraizados en sus compatriotas pero sesgan la hibridación con la alienación de la hegemonía. Latinoamérica vive con la imagen del éxito de sus actrices, pero no repara en la forma en que sus orígenes raciales son utilizados en función de crear roles y estereotipos que se vuelven "representativos" ante el resto del mundo.

A la mujer que vive en la región y observa esos roles y estereotipos, le corresponde elegir:

- Apreciar su cultura y origen y mantenerse como es.

- Buscar la clase de vida que tienen sus compatriotas en el exterior, es decir ceder ante la colonización anglosajona pero sin abandonar sus orígenes. 


\section{9}

- Asumir los roles y estereotipos impuestos en el cine comercial como la imagen verdadera de la mujer latina, lo que constituye un caso típico de alienación.

Esta transición de ideal de belleza afecta a las mujeres de los países subdesarrollados, específicamente de Latinoamérica. Antes de la "latinización" de los Estados Unidos, el boom de moda era teñirse el cabello de rubio y utilizar lentes de contacto azules o verdes para asemejarse a las mujeres caucásicas del modelo occidental. En los tiempos actuales por el cambio que viene nuevamente impuesto por los países colonizadores, las mujeres latinas han optado por hacer de sus cuerpos un altar de belleza, consiguiéndolo con más ejercicio y con operaciones estéticas que las hacen más voluptuosas. Argentina, Brasil, Venezuela y Colombia ocupan el ranking de los países con mayor demanda de cirugías estéticas.

Las mujeres latinas adoptan inmediatamente la imagen estereotipada puesto que es el modelo a seguir mientras que la imagen física de las mujeres estadounidenses (mujeres de cabello rubio y de ojos azules) sigue siendo la misma. La "latinización" no afecta la construcción de su apariencia física, no hay una influencia en la mayoría poblacional femenina.

\section{Conclusiones}

Pese a la incursión y el crecimiento poblacional de la cultura latina en los Estados Unidos, la historia y su herencia nos seguirá situando como una minoría no solo frente al país norteamericano sino frente al resto de potencias mundiales. El reconocimiento no viene dado desde el respeto de nuestra idiosincrasia y raíces sino que continúa y se propaga como la expropiación de nuestras costumbres para alienación de nuestro propio pueblo. Se trata de una forma paternalista y hegemónica de establecer el rol de la mujer latina meramente como un símbolo sexual y su reconocimiento en el mundo solo por su belleza.

La inserción de rasgos latinos en las películas del cine comercial, no corresponde nada más que a una estrategia de marketing, que uti- 


\section{0}

liza a las actrices latinas para que su mercancía llegue a la mayoría de consumidores posibles. Las actrices latinas "son productos de experiencias coloniales e históricas que causa la transformación de latinas en los Estados Unidos en objetos de sexualización racial” (Morin, 2005, p. 3 ).

No se trata de un aprecio por nuestra cultura, sino más bien de la utilización y su manipulación para fines lucrativos.

Los estereotipos utilizados en esta industria responden a las características no generalizadas de la cultura latinoamericana. Solo las características físicas y genéticas de las latinas son las que las han llevado al podio de representación de la sensualidad.

Rara vez a las actrices latinas se les asigna papeles de empresarias exitosas, científicas serias o a los roles asignados por ejemplo a las actrices norteamericanas Meryl Streep o Julianne Moore. La razón reside en el hecho de que la comunidad latinoamericana no posiciona a la mujer latina en el campo científico y empresarial. Tanto la sociedad anglosajona como la latina bajo la mirada machista recalca en la mujer latina su cuerpo por sobre su inteligencia y es también la propia mujer la que se queda con ese rol asignado. No podemos culpar en su totalidad a la sociedad anglosajona.

Las actrices latinas son buscadas y seguirán siendo buscadas en Hollywood para un único fin, la encarnación de la sensualidad. Incluso se puede observar que en las películas actuales sitúan a la morena como la chica sexy y bella o bien como la mujer que es valiente. Basta observar el cabello tinturado de acuerdo con patrones semióticos de Jennifer Lawrence o Megan Fox que relacionan esta característica con el ejemplo que se tiene de las mujeres latinas.

Para la representación de la mujer sensual y atractiva es necesario tener ciertas características latinas, el cabello castaño o negro, un cuerpo voluptuoso o los labios carnosos. Como producto de la "latinización", para generar un sex simbol es clave apropiarse de esos rasgos. Lo sexy 
siempre remitirá a las características físicas distintivas de una latina. Las propias actrices estadounidenses son llevadas a tomar el protagonismo femenino de una película caracterizando al personaje con cambios físicos que resalten ya no la belleza caucásica sino esa mixtura de ambos cánones culturales.

La mujer latina ha tenido una incursión muy distinta a la que tuvo el hombre del mismo origen. Son dos vertientes distintas, la mujer supo explotar su físico como arma de trabajo y reconocimiento mundial, mientras que los hombres optaron por incursionar como directores: Alfonso Cuarón, Alejandro González Iñárritu y Guillermo del Toro por ejemplo.

La comparación de géneros de un mismo origen conlleva a otra investigación sobre los orígenes comunes en el cine comercial: tienen la misma línea troncal de subyugación pero se separan. Origen común pero con una construcción socio-histórica que los ha colocado en un antagonismo. Mientras a la mujer latina se la pone en un podio con papeles donde su belleza es admirada, los actores latinos continúan representando papeles de trabajadores explotados, narcotraficantes, taxistas, villanos de las películas.

Los logros que consiguen nuestros representantes latinos en el país anglosajón no son vistos solo como un éxito, sino como la reivindicación de nuestra cultura y posicionamiento dentro de la mirada mundial. Es limpiar nuestra imagen y demostrar que somos capaces de obtener los mismos reconocimientos que las grandes potencias. No solo se pelea desde la reivindicación de la mujer frente a la mirada machista, también desde el posicionamiento cultural para borrar las marcas de colonización mental y cultural.

Si bien la lucha de género ha rendido sus frutos, esta pierde su poder frente al magnate del cine comercial; cambiar esta mirada de la mujer latina conlleva un cambio desde la misma sociedad de origen y el comportamiento de los migrantes dentro de EEUU. Es algo que no se puede 


\section{2}

lograr fácilmente. Basta ver cómo la cultura hacia el cuerpo ha crecido en la región, generando un culto y posicionamiento del cuerpo y la imagen.

El relativo éxito en la lucha de género no anula el hecho de que en los roles que se le asigne a la mujer latina, ésta continúe desenvolviéndose dentro de lo que la mirada masculina requiere. "La mujer es, como el hombre, un ser humano; pero tal afirmación es abstracta; el hecho es que todo ser humano concreto está siempre singularmente situado" (Beouvoir, 1998, p. 6). En el cine comercial la mujer con características latinas será en su mayoría situada como ejemplo de símbolo sexual y gran atractivo físico.

El posicionamiento de la mujer como ejemplo de éxito, viene dado desde la mirada de Latinoamérica sobre ella. No hay que olvidar que en el marketing de toda la industria cinematográfica la mujer no está definida por si misma sino en relación a lo que la industria requiere de ella. Por este círculo de dominación ideológica camuflada, en la lucha de género no se percibe ningún avance significativo. Continúa la reproducción de roles y estereotipos asignados y conllevados por la imagen de la mujer latina.

En esta lucha los extremismos son evidentes, generan una falsa conciencia en las feministas. La asociación de feminidad con subyugación ha generado nuevos estereotipos con respecto a las mujeres feministas, se les ha asignado incluso apelativos como "feminazis" por su llamado en su lucha, a la exageración y el extremismo.

Hay que profundizar en el contexto en el que se desarrollan las películas para no solo expresar una crítica superficial respecto al tema de la violencia de género. El rol que representa Letty en la franquicia de "Rápidos y Furiosos", por ejemplo, responde a la realidad de la mujer latina migrante que crece en los guetos de EEUU. Letty como personaje caracteriza a la mujer ruda y de clase baja que se involucra en pandillas, y al mismo tiempo se le otorga al personaje la belleza necesaria para que resulte atrayente al público, en relación con la realidad latinoamericana. 


\section{3}

Eva Mendes al contrario, en la misma franquicia trabaja solo el lado sensual y exótico que representa la mujer latina en la sociedad anglosajona. El personaje de Mónica a diferencia de Letty no trasciende más allá de la sensualidad y será la única arma que ella utiliza para alcanzar cualquier objetivo. No solo en la ficción la sensualidad será tomada como herramienta para la obtención de metas; es el caso de Salma Hayek, actriz migrante, quien apostó a su belleza física para lograr un posicionamiento en el cine hollywoodense. En "Desperado", película de acción, su personaje resalta por la sensualidad que denota en las escenas de acción, la ropa utilizada por su personaje por ejemplo, será entallada y ligera a pesar de que en la realidad que plantea la película sería la menos apropiada.

El personaje de Jessica Alba como súper heroína responde al contexto sociocultural de la época de estreno de "Los 4 Fantásticos" (2005 y 2007), cuando no existía un apogeo o popularidad de las franquicias de superhéroes. Alba responde a esa "valentía y rudeza que caracteriza a las latinas" convirtiéndola en la combinación perfecta por representar lo sexy, lo valiente y lo inteligente. El contexto comercial del cine apostaba a presentar figuras atrayentes tanto femeninas como masculinas (Chris Evans como la Antorcha humana).

Aunque la belleza y la buena imagen estén desvinculadas, la manipulación de los medios en el cine, ha posicionado en la mente de las mujeres que la belleza está asociada al éxito. La buena imagen no es necesariamente la copia de lo que se ha establecido como la perfección de belleza en la industria cultural. Un cuerpo voluptuoso, un color de ojos y un tipo de cabello no determina si una mujer es bella o no. Cada mujer, sin que sea juzgada por nadie, tiene el derecho a cuidar y hacer de su imagen personal lo que quiera, o si lo prefiere salir de los cánones que la industria ha determinado como la belleza absoluta.

El extremo opuesto de tomar y creer que la feminidad y la buena imagen es reproducir y continuar con la subyugación del machismo, consiste en fomentar la igualdad a base de comportamientos extremis- 


\section{4}

tas como el uso de prendas masculinas, marchas con cuerpos desnudos y condenas a todos aquellos que no apoyen sus prácticas. Esta postura también perjudica la lucha de género.

En la división hombre-mujer ambos son distintos desde el punto de vista biológico. Partiendo de esta diferencia, la igualdad se inicia con el respeto de cada individuo como tal, a partir de las diferencias que se tiene, dejando de ver al otro como un objeto ajeno a nuestra realidad. La igualdad no consiste en que los comportamientos, vestimenta, actividades, etc. deban ser los mismos; el individuo como ser solitario debe posicionarse como tal en la sociedad.

\section{Bibliografía}

Beouvoir, S. d. (1998). El segundo sexo. Buenos Aires, Argentina: Cátedra.

Butler, J. (1999). El género en disputa. El feminismo y la subversión de la identidad. Tercera ed. M. A. Muñoz, Trad. Nueva York, Estados Unidos: Paidós.

Legarde, M. (1996). Género y Feminismo: Desarrollo Humano y Democracia (Primera ed.). Madrid, España: Horas y horas. Recuperado el Marzo de 2015

Lindón, A. (agosto de 2007). Diálogo con Néstor García Canclini ¿Qué son los imaginarios y cómo actúan en la ciudad? EURE, XXXIII (99), 89-99., Obtenido de https://goo.gl/4xGUur (02-2015).

Mattelart, A., y Neveu, E. (2003). Introducción a los estudios culturales. Primera ed. París, Francia: Paidós.

Morin, S. (2005). Los Estados Unidos como otro país latinoamericano: el ideal de la belleza femenina como una manifestación de esta transformación cultural. Estudios Culturales y Cuestiones globales, 2(7). Obtenido de https://goo.gl/krZqjQ (20-03-2015).

Sorice, M. (2005). I media. La prospectiva sociológica. Roma, Italia: Carocci.

Terrero, J. M. (2006). Teorías de Comunicación. Guayana, Venezuela: Núcleo Guayana. Recuperado marzo de 2015

Williams, R. (2001). Cultura y sociedad. Londres, Inglaterra: Numendez Visión. Recuperado 23 de Enero de 2015. 


\section{Capítulo 5 Medios de comunicación privados y poder político en Ecuador 2007-2016}

Renata Lizarzaburo Palomino

Roberto Sánchez Montoya

\section{Resumen}

En el Ecuador los medios de comunicación privados han estado ligados históricamente a los grandes grupos económicos del país, no existían medios públicos y el desarrollo de los espacios comunitarios eran escasos. La posición de dominio de algunos de los grandes medios privados les permitió negociar con el Estado y la función pública en avenencia o en otros casos fueron utilizados como herramientas de presión. Desde una perspectiva crítica la presente investigación muestra los vínculos de los principales medios de comunicación del país con corporaciones privadas y describe el cambio que significó para ellos la llegada de Rafael Correa a la Presidencia de la República en el 2007, pues una de las metas del Gobierno fue regular los medios de comunicación y crear una nueva ley de comunicación.

\section{Introducción}

Hablar de los medios de comunicación en el Ecuador, por lo menos en los últimos veinte años, ha sido hablar de los entramados de poder, de silencio en algunas ocasiones y de espectáculos en otros, llegando incluso a maniatar la realidad política en busca de privilegios y concesiones (Reyes, 2010). Contrariamente a su autodefinición de "defensores de la ciudadanía" y "vigilantes del poder", algunos de los principales medios privados han estado muy vinculados a juegos de intereses políticos-económicos alrededor de la crisis financiera más grandes que ha vivido el país, sesgando la información con el objetivo de defender sus intereses particulares. 


\section{6}

Por ejemplo, algunos de los grandes medios tuvieron una actuación poco transparente durante el feriado bancario, ${ }^{14}$ cuando en marzo de 1999 el entonces presidente Jamil Mahuad decretó el congelamiento de las cuentas de los ecuatorianos que tenían más de dos millones de sucres o más de 500 dólares, para intentar salvar una banca quebrada a causa de sus malos manejos (Espinosa, 2000).

Cabe mencionar que un gran sector de la banca apoyó la campaña presidencial de Mahuad, especialmente el banquero Fernando Aspiazu. ${ }^{15}$ El exvicepresidente de ese entonces, Gustavo Noboa, señaló que cuando quebró el Banco del Progreso, Mahuad no quiso que se aprese a Aspiazu; y que cuando finalmente fue detenido el banquero aceptó que aportó a su campaña (El Comercio, 29 de mayo de 2014). Este escándalo ocasionó el derrumbe del partido Democracia Popular, al que pertenecía Mahuad (Fontaine, 2002).

Durante esta crisis, considerada la peor que vivió el país en la últimas décadas, cientos de miles de personas quedaron en la indigencia y casi tres millones de ecuatorianos migraron para poder subsistir. Los medios de comunicación de propiedad del Grupo Isaías, también vinculados a la banca ecuatoriana, se limitaron a dar cuenta de algunos testimonios de desesperación, pero nunca mostraron minuciosamente a los culpables, las vinculaciones entre políticos y banqueros, ni los delitos financieros que se cometieron (Farinango, 2011).

En Ecuador, desde su nacimiento como República, la pugna ideológico-política de movimientos proselitistas que ansiaban la toma del poder permitió que a nivel de un periodismo altamente concebido se defendieran intereses por un lado y rechazos por otro, con la finalidad

14 La crisis que ocasionó el feriado bancario se originó en el Gobierno de Sixto Durán Ballén por la liberación de las tasas de interés, la libre circulación de capitales y la entrega incontrolada de créditos millonarios, que ocasionaron fuga de capitales y especulación.

15 En ese entonces mayor accionista y presidente del Banco del Progreso, uno de los bancos más grandes del país. 


\section{7}

de hacer resistencia a los movimientos que estaban empotrados en el poder político-administrativo. Este asunto no ha cambiado hasta la actualidad (Rivera, 2014, p. 4).

Entre 1996 y 2016 en el país gobernaron: Sixto Durán Ballén, Abdalá Bucaram, Fabián Alarcón, Jamil Mahuad, Gustavo Noboa, Lucio Gutiérrez, Alfredo Palacio y Rafael Correa. Hasta antes de la llegada de este último a la presidencia, los grandes medios de comunicación y los gobiernos de turno buscaron de diferentes maneras acuerdos y/o presionaron para obtener algún tipo de rédito económico o político.

Esa antigua relación - accidentada a ratos, cordial a veces, pero siempre tensa y mutuamente interesada- se sostenía en un sinnúmero de acuerdos bilaterales tácitos, en acuerdos no escritos de vieja data, en defensa del statu quo, de la libertad de empresa, de la propiedad privada, de la economía de mercado (Ramos, 2010, p. 210).

Según Ayala y Calvache los medios de comunicación estuvieron concentrados en el sector privado y el único que pudo considerarse como un medio estatal fue la Radio Nacional del Ecuador, adscrita a la Secretaria Nacional de la Presidencia. Sin embargo, esta dependencia estaba abandonada, pues no era tan útil como los medios masivos tradicionales (Ayala y Calvache, 2009). Además, habría que considerar que también funcionaban algunas pequeñas radios vinculadas a gobiernos locales o subnacionales.

Los dueños y accionistas de los grandes medios privados no solo trabajaban en la comunicación y el periodismo, sino que también poseían empresas con gran peso en la economía nacional. La vinculación económica-mediática permitía a estos emporios aumentar su influencia dentro de temas políticos y económicos con los mandos de turno. Entonces, estos medios "no se limitaban a las actividades info-comunicacionales, sino que se ramifican al conjunto de la economía, que incluyen bancos, grandes almacenes, inmobiliarias, o aseguradoras" (Macaroff, 2010, p. 4). 


\section{8}

Sin embargo, a pesar de demostrar una lectura poco objetiva del panorama político, los canales, emisoras, e impresos tradicionales se legitimaron en las familias ecuatorianas como portadores de la verdad, pues intentan ser visualizados como neutros, y al ser "muy anteriores a los gobiernos a los cuales combaten cuentan con una legitimación muy asentada" (Follari, 2013, p. 10).

Cuando Rafael Correa asumió la presidencia del Ecuador en 2007, propuso un plan de gobierno que rompía con la lógica de Estado neoliberal que durante años había regido el país. El llamado a una nueva constitución, el derecho a la propiedad pública de los sectores estratégicos, la regulación de las formas de propiedad, la reformulación del derecho a la información, entre otras propuestas hicieron que la relación de poder que existía entre medios privados y gobierno cambie radicalmente.

... [un] hecho que cambió la estructura de propiedad de los medios ecuatorianos fue la incautación de ocho estaciones de radio y televisión, en 2008, por parte de la Agencia de Garantía de Depósitos (AGD). Estos medios pertenecían al Grupo Isaías que, además, operaba en el sistema financiero $y$, junto con otros empresarios, fue acusado de ser responsable de la crisis bancaria de 1999. De este modo, cinco canales de televisión y tres radioemisoras quedaron bajo la administración directa del Estado. (Ramos, 2013, p. 77).

Desde la creación de la nueva Constitución se impulsaron normativas para regular el ejercicio comunicativo, se habló de democratización de los medios, de una ley orgánica de comunicación y de un periodismo al servicio social. Estas y otras ideas, que se recuperaron de los viejos debates de la teoría crítica latinoamericana (Sánchez, 2013), generaron malestar entre los empresarios de la comunicación que, en su afán de recuperar el estatus y los privilegios con los que funcionaron, iniciaron una guerra mediática en contra del gobierno de Correa.

Los medios dejaron de ser los socios camuflados del poder político y, de pronto, se volvieron opositores inerciales del Gobierno. (...) carentes 
de iniciativa y de visión de largo plazo, esbozaron conductas reactivas, poco conceptuales y orgánicamente débiles. Más tarde, esa conducta de los medios los llevaría — sobre todo a partir del segundo mandato de Correa (agosto 10 de 2009) - a la puesta en práctica de una peligrosa estrategia de oposición militante al Gobierno, como forma de protección de sus valores y de sus intereses económicos concretos (Ramos, 2010, p. 211).

Algunos medios privados incluso recurrieron a organismos internacionales para cuestionar las políticas que había implementado Correa en materia de comunicación. Por ejemplo, la Sociedad Interamericana de Prensa (SIP) aseveró en varias ocasiones que la Ley Orgánica de Comunicación sería un atentado contra la libertad de expresión, alegaron que de aprobarse esta normativa el Ecuador viviría censuras como en las épocas dictatoriales más crudas de Latinoamérica, e inclusive aseguraron que el mandatario ecuatoriano buscaba "hacerse millonario" enjuiciando a los medios.

A nivel nacional, a través de la Asociación Ecuatoriana de Editores de Periódicos, AEDEP, lograron construir una voz mediática unificada, logrando convocar, además, a los exponentes de la política tradicional y a las cámaras empresarias. Ello explicaría que la Ley de Comunicación haya sido resistida desde posiciones políticas tan distintas como la Concertación, movimiento político de derecha liberal y el Movimiento Popular Democrático, partido de inspiración maoísta. Internacionalmente los medios y sus aliados, lograron convocar, a través de la Sociedad Interamericana de Prensa, a ONG como Reporteros sin Fronteras ${ }^{16}$ y Human Rights Watch. De este modo, consiguieron asociar su resistencia a la sanción de la Ley de Comunicación a una defensa de los derechos humanos de características muy sui generis (Ramos, 2012, p. 76).

Las reformas planteadas por Correa generaron un escenario donde los medios privados confrontaron abiertamente al gobierno ante lo

16 A pesar que Reporteros Sin Fronteras planteó algunos cuestionamientos, advirtió que compartía de forma general la necesidad de regular mejor a los medios de comunicación en el Ecuador. 
que ellos creen incorrecto, apelando al discurso de la libertad de expresión y del autoritarismo de Correa. La respuesta del gobierno también fue confrontacional, a través de diferentes declaraciones del propio presidente y se otros altos funcionaros del gobierno que empleaban cadenas, ruedas de prensa, entrevistas, enlaces ciudadanos para referirse al trabajo de la prensa opositora, incluso en algunos casos puntuales planteado juicios contra algunos periodistas y medios de comunicación.

Luego de la entrada en vigencia de las nuevas normas de comunicación, en uno de los primeros informes del Consejo de Regulación y Desarrollo de la Información y Comunicación se indicó que en el Ecuador funcionaban 1146 medios: 1048 privados, 63 públicos y 35 comunitarios (CORDICOM, 2014). Con estos datos se evidenció el surgimiento de los medios públicos y en menor medida de medios comunitarios.

La creación de los medios públicos fue considerado un hecho histórico en un país en el que el sistema informativo siempre estuvo en manos de las corporaciones mediáticas privadas. Así, en el 2008 “inició la gestión de los medios de administración estatal (diario El Telégrafo, Ecuador TV y Radio Pública del Ecuador)” (Ramos, 2013, p. 77).

Sin embargo, se debe señalar que los medios públicos creados durante el gobierno de Correa siguieron una lógica parecida a la de los medios privados: adoptaron una postura política y la defendían a ojos cerrados, dejando — una vez más — a la objetividad como una asignatura pendiente en temas de comunicación. Algunos periodistas dejaron de serlo para convertirse en voceros políticos. Si los medios privados respondían de acuerdo con los intereses de sus dueños, los medios públicos suelen responden al posicionamiento político de quien está en el poder. Ambos lados se llenaron de dogmas, admiración u odio por individuos, partidos políticos o ideales. Unos periodistas se convirtieron en publicistas del gobierno otros y otros en víctimas de un gobierno autoritario. Los intereses de ambos lados estaban claros: por un lado desprestigiar el accionar de los medios privados y por otro recuperar los privilegios y el status que perdieron, pasando así de mediadores a actores políticos. 
En la actualidad los medios están "marcados por distinta tendencia ideológico-política, que no educa ni presenta ninguna influencia en los niveles de escolaridad; se ubican en posturas de apoyo o de oposición al régimen” (Rivera, 2014, p. 10).

\section{Tema central de investigación}

La hipótesis planteada para este artículo sostiene que los intereses de los medios privados de comunicación, al estar condicionados por las reglas del mercado - entendiendo a la información como un negocio - no responden al bienestar colectivo de la ciudadanía, sino particularmente al de ciertos grupos hegemónicos. En este sentido, el objetivo principal de este trabajo es demostrar que los grandes medios privados no son actores sociales legítimos y que responden a intereses económicos y políticos.

Asimismo, este artículo plantea una reflexión sobre el rol que deberían asumir los medios y lo que implica un proceso de democratización. Esta investigación servirá para demostrar que en efecto, tal como se plantea desde el inicio del artículo, los medios corporativos juegan un rol político mucho más allá de sus deberes mínimos en el campo de la información como los son: la pluralidad de fuentes, verificación de datos y contrastación de información.

Este trabajo de investigación se realizó desde una perspectiva teórica cercana a los planteamientos críticos de la comunicación, y no oculta el posicionamiento político de sus autores al considerar que los medios privados actúan guiados por fines de lucro e intereses particulares y termina socavando la pluralidad informativa.

A través de una lectura hermenéutica de varios trabajos que recogen la trayectoria del funcionamiento y accionar de los medios de comunicación en el Ecuador, durante los últimos veinte años, se intentará comprender e interpretar la realidad del ejercicio mediático y periodístico en el país. Según explica Echeverría (2004), para Scheleier- 
macher toda hermenéutica es un arte de entendimiento. Para este autor la hermenéutica parte del cuestionamiento de por qué toda expresión hablada o escrita es entendida, y explica este entendimiento desde un proceso de reconstrucción histórica, adivinatorio, objetivo y subjetivo de un discurso dado. Entonces, una lectura hermenéutica tiene como principio la generación de conocimiento a través de la compresión e interpretación de un discurso, en este caso, de los textos seleccionados a partir de la investigación de sus autores, del contexto histórico en el que se desarrollaron y de la coyuntura que vive el país.

\section{Metodología}

Para iniciar el trabajo se realizó un escrutinio de artículos académicos relacionados con el tema. Este ejercicio incluyó la búsqueda en diversas revistas científicas electrónicas nacionales e internacionales, especializadas en ciencias sociales y de la comunicación.

Las bibliotecas virtuales constituyeron una base de información importante para el artículo, pues los trabajos utilizados son actuales y contienen casos de estudio específicos en el Ecuador, algo importante para el análisis que nos compete.

Al manejar un tema de importancia nacional, fue necesario recurrir a estudios académicos locales. Por ello, se examinaron repositorios virtuales de las universidades del país, sobre todo en las bibliotecas de la Facultad Latinoamericana de Ciencias Sociales (FLACSO-sede Ecuador) y de la Universidad Andina Simón Bolívar (UASB-Ecuador), ambas dedicadas a la investigación en Ciencias Sociales en el país y con programas de cuarto nivel en comunicación.

También se exploraron artículos académicos en español de las bases de datos como Scopus, ScIELO, Resh, Google Schoolar; además de otras revistas internacionales especializadas en Ciencias Sociales, y redes de investigación como la del Consejo Latinoamericano de Ciencias Sociales (CLACSO). 
Los artículos utilizados fueron desarrollados por investigadores especialistas en la materia, respaldados por centros de estudios superiores o por editoriales académicas reales. Además, para emplear un artículo se verificó que este contenga amplias referencias bibliográficas, que permitan comprobar con facilidad la veracidad de su contenido.

En primera instancia se utilizaron los siguientes criterios de búsqueda: medios privados en el Ecuador, medios privados y grupos económicos, poder mediático, medios privados en el gobierno de Rafael Correa, gobierno y prensa, medios como actores políticos, democratización de los medios de comunicación, prensa y gobiernos, historia de la prensa en Ecuador.

Luego se realizó una lectura rápida de los resultantes para escoger aquellos que documentaran el funcionamiento de los medios de comunicación en el Ecuador entre 1996 y 2016; detallaran casos políticos en los que estuviera vinculada la prensa; analizaran las normas del ejercicio comunicacional; así como los textos que establecían una comparación entre los medios antes y después del 2006. También recolectamos los trabajos que analizaban el panorama mediático de toda la región y presentaban casos específicos en diversos países de Latinoamérica.

El siguiente paso fue realizar una lectura comprensiva y hermenéutica de los textos seleccionados, e inmediatamente elaborar resúmenes con las citas textuales que sustentarían el trabajo. El resumen bibliográfico se lo dividió en tres partes: los medios antes del 2006, los medios en el gobierno de Rafael Correa, y, en casos concretos de participación de la prensa en asuntos del país.

Finalmente, fue necesario recurrir a autores clásicos de los estudios de comunicación para reflexionar sobre las concepciones comunicacionales y mediáticas y su aplicación en el mundo real, así como para comprender los nuevos enfoques comunicacionales pensados desde el desarrollo. 


\section{4}

\section{Análisis de contexto}

La comprensión del contexto nacional fue necesaria para entender las condiciones políticas y sociales que incidían en el accionar de los medios de comunicación y su repercusión en la vida política y social del país. Para ello fue preciso seguir la pista a editoriales, noticias, columnas de opinión y reportajes de los diferentes medios ecuatorianos. Con las publicaciones seleccionadas, se elaboró una línea de tiempo para visualizar las diferentes posturas que pregonaba la prensa ante los sucesos de importancia política, económica y social que ocurrieron en el país, en los últimos veinte años. Se eligió este periodo de tiempo para este estudio, porque a partir de 1996, el Ecuador atravesó una suerte de ingobernabilidad e inestabilidad política que inició con el gobierno de Abdalá Bucaram. Durante su mandato la prensa rompió los acuerdos explícitos que había mantenido con los anteriores gobiernos.

Esta "convivencia pacífica" entre el poder político y el "poder mediático" llegó bruscamente a su fin con el periodo de crisis sistémica, también llamada "crisis de la democracia" que se originó con el derrocamiento del gobierno populista de Abdalá Bucaram en 1997 (...) sus extravagancias coparon los espacios noticiosos y aun los de entretenimiento de la prensa, la radio y la televisión (...) con lo que socavó la formalidad y la seriedad que la política supuestamente debía tener (...) En este sentido, el malestar de amplios sectores de capas medias y medias altas con Bucaram se profundizó por la actuación abiertamente oposicional de varios medios, entre los cuales se destacó una emisora radial capitalina que convocó movilizaciones callejeras y una serie de eventos de protesta, que sin duda alguna repercutieron en su salida del poder (Reyes, 2010, pp. 157-158).

Para complementar la investigación se revisaron varias entrevistas, conversatorios, discursos y enlaces ciudadanos de Rafael Correa, en relación con el periodismo y los medios de comunicación. Además, se mantuvieron algunas conversaciones con periodistas independientes sobre las visiones de las nuevas leyes, y del antes y después del periodismo ecuatoriano. 
Las publicaciones de colectivos sociales y organizaciones políticas también sirvieron de apoyo para comprender como eran considerados los medios de comunicación en el imaginario colectivo, así como para entender las expectativas que generaban en estos grupos las propuestas comunicativas de Correa. Luego, éstas serían también una guía para analizar las críticas que años después se generaban frente a este mismo modelo planteado por el fundador de Alianza País.

\section{Marcos normativos}

Para determinar con precisión el contexto legal de todas las transformaciones mediáticas fue necesaria la revisión de varios instrumentos normativos como la Constitución de la República del Ecuador (2008), la Ley Orgánica de Comunicación (2013), y la Ley de Regulación y Control del Poder del Mercado (2011), además de otros informes solicitados por el Estado para la construcción de políticas públicas como el Informe definitivo de la Comisión de Auditoría de Frecuencias. Asimismo, se repasaron premisas internacionales referentes a la comunicación en organismos internacionales como la Unesco.

\section{Resultados}

\section{Medios y poder económico}

A partir del ejercicio de comprensión e interpretación de las investigaciones recogidas para este trabajo, vemos que en el país existió y aún existe un acceso inequitativo a la comunicación y a la información. La comunicación de los medios masivos ha sido entendida como un negocio y no como un derecho constitucional y humano.

Desde el 2008 la Constitución ecuatoriana prohibió la participación de banqueros en los medios de comunicación y determinó 24 meses de plazo para que los miembros de la banca vendan las acciones que tenían los medios del país. De igual forma con la Ley de Regulación y 
Control del Poder del Mercado conocida como antimonopolio, se ratificó la restricción sobre la participación de los banqueros en los medios de comunicación. Esta ley evitaría la concentración del poder del mercado en pocas manos y propiciaría que los empresarios se enfoquen en su actividad económica principal.

El informe definitivo de la Comisión de Auditoría de reveló que 118 banqueros vinculados a 201 medios de comunicación debían deshacerse de sus acciones. El documento, además determinó que de 1.637 frecuencias concesionadas unas 900 tendrían problemas legales.

Entre las causales de ilegalidad se puede mencionar el incumplimiento del contrato por falta de pago de seis meses o más en las obligaciones de la empresa, la disolución de las empresas concesionarias, la terminación de la concesión, la falta de informes de ingeniería o autorización, y el funcionamiento de repetidoras sin programación regular (Ecuador Inmediato, 2008).

Entre los grupos económicos vinculados a medios de comunicación en Ecuador estaban:

Tabla 1

Grupos económicos del Ecuador

y su vinculación en medios de comunicación

\begin{tabular}{|c|c|c|c|}
\hline $\begin{array}{c}\text { Grupo } \\
\text { económico }\end{array}$ & $\begin{array}{l}\text { Entidades } \\
\text { bancarias }\end{array}$ & $\begin{array}{c}\text { Medios } \\
\text { de comunicación }\end{array}$ & Otras empresas \\
\hline Isaías & Filanbanco & $\begin{array}{l}\text { - TC Televisión } \\
\text { - Gamavisión } \\
\text { - Cable Deporte } \\
\text { - Cable Noticias } \\
\text { - Diario Expreso } \\
\text { - Radio Bolívar } \\
\text { - Radio Sideral } \\
\text { - Radio Sonorama } \\
\text { - Radio Súper K } 800 \\
\text { - Revista Más } \\
\text { - Revista La Onda }\end{array}$ & $\begin{array}{l}\text { - Ingenio San } \\
\text { Carlos } \\
\text { - TV Cable }\end{array}$ \\
\hline
\end{tabular}




\begin{tabular}{|c|c|c|c|}
\hline $\begin{array}{c}\text { Grupo } \\
\text { económico }\end{array}$ & $\begin{array}{l}\text { Entidades } \\
\text { bancarias }\end{array}$ & $\begin{array}{c}\text { Medios } \\
\text { de comunicación }\end{array}$ & Otras empresas \\
\hline Egas-Grijalva & $\begin{array}{l}\text { - Banco del } \\
\text { Pichincha } \\
\text { - Dinners } \\
\text { Club } \\
\text { - Banco } \\
\text { Rumiñahui } \\
\text { - Banco Loja }\end{array}$ & $\begin{array}{l}\text { - } \text { Teleamazonas } \\
\text { - Revista Mundo } \\
\text { - Revista Gestión } \\
\text { - Revista Soho } \\
\text { - Revista Gente } \\
\text { - Revista Fucsia } \\
\text { - Diario Hoy } \\
\text { - Radio Bolívar }\end{array}$ & Multicines \\
\hline Mantilla-Ortega & $\begin{array}{l}\text { Consorcio del } \\
\text { Pichincha }\end{array}$ & $\begin{array}{l}\text { - Diario El Comercio } \\
\text { - Diario Últimas } \\
\text { Noticias } \\
\text { - Radio Quito } \\
\text { - Radio Platinum } \\
\text { - Ecuadoradio } \\
\text { - Revista Carburando } \\
\text { - Revista Líderes } \\
\text { - Revista Familia } \\
\text { - Revista Pandilla }\end{array}$ & $\begin{array}{l}\text { - } \text { Swiss Hotel } \\
\text { - Metropolitana } \\
\text { de Seguros }\end{array}$ \\
\hline Alvarado - Roca & & $\begin{array}{l}\text { - Ecuavisa } \\
\text { - Revista Vistazo } \\
\text { - Revista Estadio } \\
\text { - Revista Hogar } \\
\text { - Revista Generación XXI }\end{array}$ & Edina \\
\hline Eljuri & $\begin{array}{l}\text { Banco del } \\
\text { Azuay }\end{array}$ & $\begin{array}{l}\text { - Telerama } \\
\text { - TV Cable }\end{array}$ & $\begin{array}{l}\text { - Almacenes } \\
\text { - Juan Eljuri } \\
\text { - Hoteles } \\
\text { Sheraton } \\
\text { - Hotel Hilton } \\
\text { Colón } \\
\text { - Automotores } \\
\text { continental } \\
\text { - La Taberna } \\
\text { - Metrocar } \\
\text { - Aymesa }\end{array}$ \\
\hline
\end{tabular}


128

\begin{tabular}{|c|c|c|c|}
\hline $\begin{array}{c}\text { Grupo } \\
\text { económico }\end{array}$ & $\begin{array}{l}\text { Entidades } \\
\text { bancarias }\end{array}$ & $\begin{array}{c}\text { Medios } \\
\text { de comunicación }\end{array}$ & Otras empresas \\
\hline Noboa & & Telecuatro & $\begin{array}{l}\text { - Industria } \\
\text { Molinera } \\
\text { - Azucare- } \\
\text { ra Valdez, } \\
\text { - Industria } \\
\text { Cartonera } \\
\text { Ecuatoriana } \\
\text { - Exportadora } \\
\text { Bananera } \\
\text { Noboa } \\
\text { - Naviera del } \\
\text { Pacífico } \\
\text { - Compañía } \\
\text { Nacional de } \\
\text { Plásticos } \\
\text { - Líneas Aéreas } \\
\text { Nacional del } \\
\text { Ecuador S.A. } \\
\text { (LAN). }\end{array}$ \\
\hline
\end{tabular}

Fuente: Tomado de Sánchez (2010). Elaboración propia.

En este sentido, se observa que los espacios mediáticos fueron absorbidos por corporaciones vinculadas a grandes grupos empresariales, y al tener influencia en la economía del país lograron obtener un distintivo de "intocables" con los gobiernos de turno. De igual forma, al responder a los requerimientos de los sectores más conservadores y a las demandas de sus financistas, olvidaron su compromiso social de informar.

En enero del 2012 el salario mínimo sectorial para los periodistas estaba fijado en 482.40, pero este valor remunerativo era incumplido con frecuencia. En diciembre del 2012, después de un nuevo análisis, el gobierno fijó el salario básico para los periodistas titulados en 800 dólares y para los no titulados en 670 dólares.

En el sector de la comunicación la precarización laboral siempre estuvo presente. Esta reforma, sin duda, golpeó las finanzas de los 
dueños de los medios quienes durante años pagaron a sus trabajadores sueldos menores a la remuneración básica establecida.

Tampoco cobraban horas extras y eran obligados a trabajar más de las 40 horas semanales establecidas en la ley.

En Ecuador había medios que pagaban a sus empleados con arroz y azúcar. Pese a que el gobierno ecuatoriano decretó que el Salario Mínimo Sectorial para el periodista es de \$482,40 (...) Uno de los entrevistados, colaborador en una radio guayaquileña, aseguró que su salario es de \$220 mensuales (...) En su caso, el salario por hora es de menos de \$1. (Agencia Pública de Noticias Andes, 2012, pp. 5-7).

Otro duro golpe fue la disminución de los contratos con medios privados para publicidad de las instituciones de gobierno. En junio del 2009, el gobierno anunció que el Estado no contrataría con empresas domiciliadas en paraísos fiscales. "Diarios como El Comercio, El Universo o La Hora o revistas como Vanguardia, con empresas accionistas domiciliadas en las Islas Caimán, Vírgenes o Bahamas, hubieron de reformar su accionariado para no verse privados de esa publicidad" (Checa, 2012, p. 52).

Esta normativa incrementó la oposición y crítica al gobierno de Rafael Correa. Uno de los casos más relevantes fue del diario Hoy, que en junio del 2014 anunció la suspensión rotativo impreso aduciendo regulaciones restrictivas e inclusive inconstitucionales por parte del gobierno. El periódico digital, ahora desaparecido, publicó en su editorial del domingo 29 de junio del 2014 que el permanente boicot publicitario a su medio y la cancelación de contratos de impresión especialmente de textos escolares, y otras limitaciones para financiar sus operaciones, incluyendo la iniciativa de transformar la información en servicio público, llevaros a sus directivos a tomar la decisión de suspender la edición impresa diaria ${ }^{17}$ (El Universo, 2014).

17 Diario Hoy salió del aire, pero el editorial de aquella fecha está registrado en varios medios, entre ellos Diario El Universo, del que se ha tomado la información. 
Sin embargo, una investigación de la Agencia de Noticias Andes determinó que el periódico suspendió su versión impresa a causa de malos manejos administrativos, y que diario HOY (Edimpres) venía generando pérdidas como desde hace quince años (ocho años antes del gobierno de Correa y 14 años antes de la vigencia de la Ley de Comunicación). La investigación también señala que por el bajo tiraje que tenía el rotativo, dejó de ser atractivo para las empresas de publicidad (Agencia Pública de Noticias Andes, 2014).

La compañía solo obtuvo ganancias en 2004, 2005 y 2006, esto esclarece que el cierre del rotativo no se debe a temas relacionados con la Ley de Comunicación (vigente desde junio de 2013), sino con problemas financieros permanentes del periódico. (Agencia Pública de Noticias Andes, 2014, p. 4).

Las políticas en materia de Correa no lograron solventar las deficiencias en el acceso y contenido de los medios, tampoco resolvieron los debates sobre el verdadero papel de los medios, mucho menos transformó a los medios públicos en emisores de información plural. Lo que debemos reconocer es que durante su gestión consiguió avances importantes como la mejora salarial para los periodistas e inclusive algunos espacios de capacitación y profesionalización, actividades que en el pasado no eran requisitos indispensables para ejercer esta profesión.

Las empresas privadas demostraron una constante negativa a evaluar su accionar, a repensar sus funciones y a ampliar su agenda pensando en necesidades colectivas. Más bien se engancharon en un juego de poder, en un "va y viene" de agravios, en una contienda personal con el gobierno. Y sin darse cuenta comenzaron de a poco a ser reemplazados por fuentes alternativas de información que, si bien aún no tienen una comprensión legítima entre la ciudadanía, van consolidando nuevas formas de hacer comunicación.

Los cambios antes mencionados tienen también evidentes consecuencias en el rol que cumplen los medios tradicionales de comunicación, que se ven enfrentados al riesgo de dejar de ser actores importantes en 
las sociedades contemporáneas, si no reformulan la forma en la que producen la información y se relacionan con los receptores de la misma (Saffon, 2007, p. 4).

\section{Medios y pluralidad}

El reconocimiento de la pluralidad y de la equidad en los medios, la creación de una ley de comunicación, y la regulación de los emporios mediáticos lograron que ciertos sectores ciudadanos, como las organizaciones y colectivos sociales vean a la comunicación desde un nuevo ángulo: como un derecho, y que desde esta concepción piensen en empoderarse y abanderar nuevos espacios informativos.

Actualmente, la ciudadanía es más crítica, ha empezado a cuestionar los contenidos mediáticos y busca formas para contrarrestar y verificar la información que se le ofrece. Sin duda camina hacia la comprensión de que al reconocer y ejercer la comunicación como derecho, tiene también una corresponsabilidad con la sociedad.

En ese sentido, el derecho a la comunicación reclama la existencia de espacios tecnológicos y sociales abiertos para el intercambio de información, el debate y el diálogo democráticos, que faciliten la construcción de consensos e imaginarios colectivos, materialicen la participación y fortalezcan la ciudadanía (Saffon, 2007, pp. 20-21).

El Estado tiene la obligación constitucional de asegurar la pluralidad de los contenidos de los medios de comunicación. Mientras más agendas informativas ofrezcan, mayor será la participación social que generen. El artículo 17 de la Constitución ecuatoriana sostiene que "el Estado fomentará la pluralidad y la diversidad en la comunicación, y al efecto facilitará la creación y el fortalecimiento de medios de comunicación públicos, privados y comunitarios" (Asamblea Constituyente, 2008, p. 25).

Este planteamiento de democratizar los medios de comunicación fue ratificado con la aprobación de la Ley Orgánica de Comunicación 
en 2013, que en su artículo 106 establece la redistribución de las frecuencias de radio y televisión "en 33\% para el Estado, 33\% para el sector privado y $34 \%$ para el comunitario" (Asamblea Nacional, 2013, p. 19).

En el 2016 se abrió un primer concurso público para la adjudicación de frecuencias de radiodifusión y de televisión de señal abierta, para entregar 846 frecuencias en FM, 148 en AM y 478 para televisión. Las solicitudes para las adjudicaciones estuvieron abiertas hasta junio del 2016, para recibir los informes técnicos, los planes de gestión y la información legal.

Después los expedientes mejores puntuados se remiten al Consejo de Regulación y Desarrollo de la Información y Comunicación (Cordicom) para que evalúen los proyectos comunicacionales. El siguiente paso será remitir un informe vinculante por cada frecuencia para notificar a los ganadores, quienes deberán suscribir y registral el título habilitante en el Registro Nacional respectivo.

Estas nuevas normas que regulan el ejercicio comunicativo en el Ecuador son necesarias para promover el desarrollo y garantizar esta pluralidad. Los medios no pueden regirse solo por las leyes del mercado, pues bajo esos parámetros no cumplirían con la función de servicio social con la que fueron concebidos.

Se entiende entonces, que la comunicación es un elemento central para el desarrollo. Y construir una comunicación vinculante es una tarea del Estado, de la empresa mediática, la academia, y desde luego, de la ciudadanía.

Los medios comunitarios y ciudadanos abren las puertas a un modelo comunicativo más cercano e incluyente en el que los ciudadanos pueden canalizar los recursos tecnológicos para generar procesos educativos, compartir experiencias laborales, de emprendimiento, de cuidado familiar, en temas de salud, y otros campos que beneficien a las poblaciones y fomente la participación de todos los ciudadanos como actores sociales. 
La nueva legislación y el proceso de democratización de los medios abren una puerta para la participación de las comunidades. La comunicación al servicio social, "la comunicación para el desarrollo eficaz no se limita al suministro de información, sino que también implica la comprensión de las personas, de sus creencias y valores, y de las normas sociales y culturales que rigen sus vidas" (Unicef, 2008).

En este proceso la participación ciudadana es fundamental. Una ciudadanía empoderada no solo construye medios plurales sino que asume su función de observador y vigilante de los medios de comunicación. Observa, cuestiona, debate, denuncia abusos y así "contribuye a la construcción de un periodismo hecho desde abajo, vigilante del poder (del contrario y del afín), riguroso y veraz, un instrumento al servicio de una comunidad con la que se comparten maneras de pensar y de ver e interpretar el mundo" (López, 2014, p.18).

\section{Medios como actores políticos}

Las organizaciones periodísticas se han convertido en actores de considerable significación en el sistema político y, a pesar que no poseen explícitamente objetivos políticos claramente definidos, actúan como actores políticos que legitiman, seleccionan e imponen los asuntos públicos (Castillo, 2011, pp. 18-19).

En sus alocuciones los medios privados evocan constantemente que son objetivos e imparciales, sin embargo, en la mayoría de veces, sus titulares no son informativos, sino políticos. En nombre de la libertad de prensa han viralizado supuestas luchas políticas que no son otra cosa que pugnas por poder simbólico o por prebendas económicas.

Ellos (los medios) elevan o hunden a los líderes políticos en las discusiones parlamentarias, intervienen en los procesos electorales y ofrecen un sinnúmero de fuentes de información a los electores, de manera que, en efecto, éstos creen vivir en democracia y que lo que deben buscar es la información; la cual les parece encontrarla validada en la importancia de los líderes de opinión (Aguirre, 2013, p. 6). 
134

En este sentido, la regulación mediática es necesaria para evitar que la presencia de los medios interfiera en la dinámica política del país y en las decisiones públicas, pues la agenda política y económica de la nación ha sido manejada durante décadas desde los requerimientos de los emporios mediáticos privados.

La promulgación de normas rectoras en torno a la comunicación devolvieron al Estado el rol rector y la obligación de velar para que los medios cumplan con su función en la sociedad: "de presentar los hechos dentro de una situación y en un momento determinado, en un aquí y en un ahora, no danzando al son de los compases de los estamentos de poder, sino al compás de la música de las realidades sociales" (Ortiz, 2002, p. 2).

Los medios no tienen la verdad absoluta, y ante esa afirmación han rechazado la crítica y "se han negado a la autocrítica. Eso los ha puesto contra la pared porque han actuado como juez y parte. Han hecho mal en responder en términos políticos y no periodísticos" (Abad, 2010, p. 197).

Si bien el Gobierno de Correa ha puesto en escena todos los defectos de los medios, su crítica parece no haber cambiado la percepción que tenía la gente sobre ellos. Según datos de la encuestadora Informe Confidencial, en febrero del 2007, en Quito, 53\% de la población tenía una valoración positiva de los medios. Mientras que el $46 \%$ de la población dio una valoración negativa. Los datos en Guayaquil son más favorables para los medios con un $66 \%$ positivo y un $34 \%$ negativo. En julio del 2009 , según la misma encuestadora, los medios tenían un 55\% de valoración positiva y un 43\% de valoración negativa en Quito. Mientras en Guayaquil alcanzaban un 68\% positivo y un 31\% negativo (Abad, 2010).

\section{La protesta policial}

Un suceso en el que pudo identificarse el rol político de los medios privados de comunicación ocurrió durante la revuelta policial del 30 de septiembre del 2010, cuando Rafael Correa fue retenido por más 
de diez horas en el Hospital de la Policía. Los miembros de la fuerza pública pedían la derogación de la Ley de Servicio Público, que a su criterio, eliminaba las compensaciones por ascenso y las condecoraciones.

La transmisión de estos sucesos, a través de los principales canales privados de televisión, generó un ambiente de pánico y descontrol en la colectividad. Pues aparte de los hechos transmitían de forma reiterada los saqueos que vivían la ciudad a causa del cese de la función policial, e inclusive ciertos medios fueron usados como palestra de discursos golpistas.

Teleamazonas instaló una microonda en vivo en el lugar de los hechos, incluso antes de tener claridad sobre lo que ocurría. Uno de los periodistas de este canal aseguró que un militar, a través de una llamada personal, le había pedido comunicar que las Fuerzas Armadas se unirían a la protesta, a pesar de que la institución había rechazado el intento de golpe.

A partir de las 14:00 los medios tuvieron que unirse a la señal de los medios públicos en una cadena que la Secretaría de Comunicación consideró pertinente para tener el control de lo que se transmitía. Hasta vincularse a la cadena nacional, los medios privados jamás mencionaron un posible golpe de estado y siempre manejaron el tema como una simple protesta policial. Estos sucesos muestran que los medios se esforzaron para manejar el intento de golpe de Estado como una situación legítima, como un derecho de los policías. Esto reafirma la teoría de que los medios no son objetivos, y que han desempeñado un rol político en contra de quienes pueden amenazar sus privilegios.

\section{Los otros medios y el otro periodismo}

Los medios públicos en el Ecuador nacen como una apuesta de Rafael Correa para democratizar el acceso a los medios y para diversificar y pluralizar la programación de los medios tradicionales. Aunque existen actualmente muchos debates en torno a qué es lo público y al rol que desempeñan estos medios en el país, se puede decir que los medios públicos por si solos son un hito (Ordóñez, 2011, p. 7). 


\section{6}

Los medios públicos han intentado acercarse a una programación con contenidos educativos, informativos y culturales, no obstante, y a nueve años de su creación, siguen existiendo vacíos en torno a su concepción y función. Es perceptible, que en los últimos años, sus contenidos han mostrado un trabajo periodístico muy apegado a la agenda del presidente.

Además, en todo el tiempo desde su creación, no han logrado vincular su propuesta periodística a la ciudadanía. Esto demostraría que desde lógicas e intereses distintos los medios públicos y los medios privados no funcionan distinto.

Por otro lado, se puede decir que los medios de comunicación comunitarios representan una oportunidad real para democratizar la comunicación, pues su trabajo responde a necesidades informativas reales de los diversos conglomerados sociales. Aquí el ejercicio periodístico no da cuentas a poderes económicos sino a los integrantes de una comunidad que intenta debatir y consensuar sobre problemáticas políticos y sociales que influyen en su vida cotidiana.

Uno de los conceptos de medios populares, alternativos y comunitarios sostiene que éstos buscan construir lazos de comunicación distintos en la sociedad, garantizan la pluralidad de voces, asumen la responsabilidad en la construcción de las identidades culturales, muestran realidades ajenas a la corporación mediática, construyen una comunicación solidaria, participativa y plural, para defender los intereses de los sectores populares (Documento de la Coordinadora en Defensa de la Comunicación Comunitaria, Alternativa y Popular, 2011).

En el Ecuador existen pocos medios que no responden emporios económicos y que están en manos de ciudadanos de a pie. La mayoría son radios online que le han apostado a contenidos "alternativos", principalmente relacionados con temas que los medios convencionales no tratan y en los que interactúan y debaten directamente con los ciudadanos, construyendo otra comunicación desde espacios netamente populares. 
Una de las primeras experiencias en este campo nació de la idea del párroco Joaquín Salcedo de utilizar la radio para educar e informar a las poblaciones rurales del municipio colombiano de Sutatenza. Este proyecto no se limitaba a un discurso educativo extensionista, más bien estaba basado en la participación activa de los campesinos.

Esta idea fue replicada en varios países de América Latina y en el Ecuador, por ejemplo, las radios populares recogieron este método para enfocarlo en la alfabetización. En 1962 Monseñor Leonidas Proaño fundó las Escuelas Radiofónicas Populares del Ecuador (ERPE), dedicadas a la alfabetización, educación y evangelización de las comunidades indígenas. Todas estas experiencias radiofónicas formaron después la Coordinadora de Radio Popular Educativa del Ecuador (CORAPE), que fueron medios alternativos al servicio comunitario. Sin embargo, por diversos conflictos económicos, e inclusive religiosos no cumplieron con su objetivo. Estas experiencias propiciaron la creación de medios comunitarios desde las diferentes comunidades populares y organizaciones sociales para generar espacios educativos, informativos y de retroalimentación de experiencias (Serrano, 2011).

Aparte de las radios comunitarias también tuvieron auge los programas juveniles alternativos en franjas que promocionaban especialmente radio La Luna y Latina FM. Cuando estas emisoras cerraron esos espacios, se comenzaron a buscar nuevas alternativas como las radios en internet. Esta ha sido una opción revolucionaria ante la inaccesibilidad a las frecuencias radioeléctricas, además, otra de sus ventajas es que al transmitirse por internet puede universalizar los procesos comunicativos, fuera de las fronteras de los países. Tal vez, más que las leyes, el internet se ha encargado de generar encuentros comunicativos.

Los medios de comunicación en todas sus formas son vitales para la sociedad, para la generación del debate, y para la concreción de acuerdos sociales, por ello es importante repensar en su función social y avanzar hacia la diversificación de esos espacios. Los medios alternativos 
y comunitarios son necesarios para avanzar con la lógica de descentralizar la comunicación y apartarla de los poderes económicos.

\section{Conclusiones}

Como resultado del proceso de investigación se puede concluir que los medios de comunicación son importantes en una sociedad democrática, porque una de sus funciones es generar opinión pública, sin embargo, su frontal oposición o favoritismo hacia un gobierno y a los diversos temas de interés colectivo, pone en duda su objetividad e imparcialidad.

$\mathrm{Al}$ analizar diversas tesis se ha observado que durante años los medios han tenido cierto protagonismo en la esfera política del país, y en algunos casos han influido en cuestiones de relevancia nacional. Sin embargo, los autores utilizados para argumentar este trabajo concuerdan en que los medios no son actores políticos legítimos, pues su accionar está atravesado por intereses particulares.

En este sentido, se puede concluir que los medios privados no deberían ser la cabeza visible de los sectores de oposición. La función de los medios de comunicación no es juzgar, ni criminalizar, es hacer periodismo en lugar de política.

Queda claro también que el Gobierno de Rafael Correa impuso transformaciones en el ejercicio periodístico, y esto generó resistencia entre los grupos económicos que manejaban las corporaciones mediáticas de país. Estos cambios convirtieron a una buena parte de los grandes medios privados en firmes opositores a su régimen, intentando recuperar su status quo, mediante la defensa de un sistema dominante e inequitativo.

El análisis también lleva a concluir que las normativas son necesarias para ejercer con responsabilidad el periodismo y que es vital entender que dentro del ejercicio comunicativo existe un compromiso 
con la sociedad y por ello es más importante un trabajo de calidad que el impacto publicitario de un periodismo pautado por disposiciones empresariales. La comunicación como toda actividad profesional y de interés público debe estar normada.

El carácter de influencia masiva presente en los medios hace que la comunicación tenga una responsabilidad trascendental con la sociedad. Por ello, es importante que quienes la ejerzan tengan presente códigos éticos que transparenten su funcionamiento y su accionar. La razón de ser de un comunicador está en el servicio a la ciudadanía.

Ante las críticas y las observaciones que han recibido los medios no se plantearon seriamente realizar una autoevaluación de sus funciones, más bien han optado por enfrentamientos con el gobierno, lo que pone en evidencia sus intereses. Los textos sugeridos han permitido establecer que no existe objetividad en el ejercicio informativo pues los contenidos están enmarcados en agendas particulares.

En este panorama, se puede determinar que los medios públicos son el inicio para una comunicación que transforme los patrones informativos actuales e impulse el empoderamiento ciudadano. De esta forma los medios públicos y comunitarios serán espacios reales para el debate de problemáticas locales y nacionales en donde se puedan generar consensos y propuestas que impulsen el desarrollo social.

Ahora existen mayores garantías para ampliar la presencia de los medios desde manos ciudadanas, sin embargo, aún no existe el empoderamiento suficiente quizá por la falta de compresión, socialización de la ley y su ejecución, o de convencimiento social. Es necesario que la ciudadanía crea en su capacidad para aportar al progreso y al desarrollo.

La ciudadanía tiene la obligación de ser propositiva y políticamente activa; los ciudadanos tienen que negarse a ser vistos como incapaces de poseer iniciativas, asumiendo posiciones críticas, de reflexión o tomando decisiones. Para ello, la academia tiene un rol fundamental, 
pues su misión es construir conocimientos de acuerdo con las nuevas realidades que se generan en el país. Además, también tiene en sus manos la oportunidad de formar no solo profesionales de calidad, sino seres humanos comprometidos con el progreso y el desarrollo social.

Las investigaciones sobre comunicación en el Ecuador son importantes para entender el momento político y social que vive el país. Estos documentos permiten contrarrestar la experiencia periodística en las calles con las lecturas más académicas del fenómeno periodístico, para analizar y establecer desde ambas lógicas las falencias, virtudes, y nuevos retos de la profesión.

Apoyada por la academia, la ciudadanía podría generar espacios comunicativos para que nuevos gestores de la información puedan posicionar otros escenarios mediáticos para el debate y la toma de decisiones.

El conocimiento de la historia de los medios en el país es indispensable, tanto para la formación de estudiantes como para el desarrollo de políticas públicas. Conocer los hechos históricos vinculados a la comunicación es fundamental para repensar el ejercicio periodístico.

Asimismo, al evaluar las normativas vigentes en temas de comunicación, se puede concluir que todavía existe una brecha entre las leyes y la ejecución de las mismas. Es una obligación del Estado impulsar el cumplimiento de las políticas públicas, socializando y promoviendo los beneficios de las mismas. No basta con promulgar leyes es necesario socializarlas y ejecutarlas.

La generación de políticas públicas en temas comunicativos debería estar enlazada al sector académico, pues los procesos investigativos que se generen en las universidades serían de gran valor para construir políticas con base en experiencias reales y con el acompañamiento de expertos en la materia.

Las formas de comunicación, sus tecnologías, evolucionan vertiginosamente y es un imperativo analizar si las políticas existentes son 
útiles en la actual coyuntura o es necesario replantearse nuevos análisis e investigaciones para formular otras premisas que ayuden a fortalecer el derecho comunicativo en el Ecuador. Son necesarias nuevas investigaciones para evaluar cómo están funcionando las leyes y políticas que se crearon para regular la comunicación. Se requiere cuestionarse si estas han permitido avanzar en algún aspecto del campo comunicativo.

Asimismo, es necesario indagar el estado de redistribución de frecuencias, pues en casi seis años solo alrededor del 5\% de frecuencias pertenece a medios comunitarios. En este sentido, las organizaciones sociales, deberían exigir que esta política se ejecute, pues todavía la comunicación está centrada en manos privadas. Por último, también resulta necesario evaluar el funcionamiento de los medios de comunicación públicos durante la última década.

\section{Bibliografía}

Abad, G. (2010). ¿Por qué nos odian tanto? Estado y medios de comunicacion en América Latina. Bogotá: Centro de Competencia en Comunicación.

Agencia Pública de Noticias Andes (22 de diciembre de 2012). Gobierno de Ecuador anuncia histórico incremento del salario básico de los periodistas y trabajadores de la comunicación. Quito, Pichincha, Ecuador.

(1 de julio de 2014). Diario HOY registraba graves problemas económicos catorce años antes de la vigencia de la Ley de Comunicación. Quito, Pichincha, Ecuador.

Aguirre, J. (2013). La participación ciudadana mediática para descentralizar al Estado. Red de Revistas Científicas de América Latina y el Caribe, España y Portugal, 6.

Asamblea Constituyente (2008). Constitución del Ecuador. Montecristi, Manabí, Ecuador: Asamblea Constituyente.

Asamblea Nacional. (25 de junio de 2013). Ley Orgánica de Comunicación. Quito, Pichincha, Ecuador: Asamblea Nacional.

Ayala, A., y Calvache, M. B. (2009). Percepción sobre los medios públicos en Ecuador. Quito: Ciespal.

Castillo, A. (Abril de 2011). Razón y palabra. Primera revista electrónica en América Latina especializada en comunicación. Obtenido de https://goo.gl/x9eZvc 
Checa, A. (2012). La Banca y la propiedad de los medios: el caso Ecuador. Revista Latina de Comunicación Social, 52.

Comisión de Auditoría de Frecuencias (2009). Informe definitivo de la Comisión de Auditoría de Frecuencias. Quito: Comisión de Auditoría de Frecuencias.

Consejo de Regulación y Desarrollo de la Información y Comunicación (27 de Enero de 2014). Consejo de Regulación y Desarrollo de la Información y Comunicación. Obtenido de https://goo.gl/cEBKN3

Coordinadora en Defensa de la Comunicación Comunitaria, P. y. (1 de septiembre de 2011). Alba TV. Comunicación desde los pueblos. Obtenido de https://goo.gl/ALblbt

Documento de la Coordinadora en Defensa de la Comunicación Comunitaria, Alternativa y Popular. (2 de octubre de 2011). En defensa de la comunicación. Obtenido de https://goo.gl/WiyWWk

Echeverría, R. (2004). El búho de Minerva. Introducción a la filosofía moderna. Santiago: Lom Ediciones S.A.

Ecuador Inmediato (14 de julio de 2008). Aparece la lista corrupta de retiro de concesión de frecuencias de radio. Quito, Pichincha, Ecuador.

El Universo (29 de junio de 2014). En editorial, diario Hoy anuncia el cierre de un ciclo e inicio de etapa digital. Quito, Pichincha, Ecuador.

Espinosa, R. (2000). La crisis económica financiera ecuatoriana de finales de siglo y la dolarización. Quito: UASB.

Farinango, L. (2011). Medios de comunicación en la vida política de los ecuatorianos. Íconos. Revista de Ciencias Sociales, 3.

Follari, R. (2013). Medios, populismo y poder en América Latina. Íconos. Revista de Ciencias Sociales, 43, mayo

López, S. (30 de junio de 2014). Pueblos. Revista de información y debate. Obtenido de https://goo.gl/wMji2d

Macaroff, A. (2010). ¿Es posible democratizar la comunicación? Debates sobre los medios públicos y privados en Ecuador. Íconos: Revista de Ciencias Sociales, 3.

Ordóñez, R. (2011). Nacimiento de los medios públicos en el Ecuador. Revista del Centro Andino de Estudios, 7.

Ortiz, C. (2002). El papel de los medios de comunicación en una situación de violencia como la colombiana. Revista Latina de Comunicación Social, 2.

Ramos, H. (2010). La palabra rota, seis investigaciones sobre periodismo ecuatoriano. Quito: Fundación Andina para la observación y estudio de medios. 


\section{3}

Ramos, I. (2012). La contienda política entre los medios privados y el gobierno de Rafael Correa. Revista Internacional de filosofía iberoamericana y teoría social, 12.

(2013). Trayectorias de democratización y desdemocratización de la comunicación en Ecuador. Íconos. Revista de Ciencias Sociales, 77.

Reyes, H. (2010). Pos-neoliberalismo y luchas por la hegemonía en Ecuador. Los entrecruces entre la política y la comunicación. En S. Sel, Políticas de comunicación en el capitalismo contemporáneo (pp. 157, 158). Buenos Aires: Clacso.

Rivera, J. (2014). Rafael Correa y las elecciones 2006. Inicios del Marketing y Comunicación. Chasqui, 4.

Saffon, M. P. (2007). El derecho a la comunicación: un derecho emergente. ANDI - Comunicación y derechos.

Sánchez, A. (2010). La relación entre los la propiedad y dominancia de los medios de comunicación masiva y la libertad de expresión e información social de las personas. Caso de la Televisión. Flacso Andes. Obtenido de https://goo.gl/yx12iQ (01-2016).

Sánchez, R. M. (2013). Apuntes para el debate ecuatoriano sobre medios: Distribución de frecuencias, ¿posibilidades para la educomunicación. Alteridad, Revista de Educación, 162-170.

Serrano, D. (22 de julio de 2011). Comunicación participativa para el desarrollo. Obtenido de https://goo.gl/DSKHLw

Unicef (2008). Unicef. Obtenido de Comunicación para el Desarrollo: https:// goo.gl/NDN4Ue 
